\title{
Results of Water and Sediment Toxicity Tests and Chemical Analyses Conducted at the Central Shops Burning Rubble Pit Waste Unit, January 1999
}

by

W. L. Specht

Westinghouse Savannah River Company

Savannah River Site

Aiken, South Carolina 29808

This paper was prepared in connection with work done under the above contract number with the $U$. $S$. Department of Energy. By acceptance of this paper, the publisher and/or recipient acknowledges the U. S. Government's right to retain a nonexclusive, royalty-free license in and to any copyright covering this paper, along with the right to reproduce and to authorize others to reproduce all or part of the copyrighted paper. 


\section{DISCLAIMER}

This report was prepared as an account of work sponsored by an agency of the United States Government. Neither the United States Government nor any agency thereof, nor any of their employees, makes any warranty, express or implied, or assumes any legal liability or responsibility for the accuracy, completeness, or usefulness of any information, apparatus, product, or process disclosed, or represents that its use would not infringe privately owned rights. Reference herein to any specific commercial product, process, or service by trade name, trademark, manufacturer, or otherwise does not necessarily constitute or imply its endorsement, recommendation, or favoring by the United States Government or any agency thereof. The views and opinions of authors expressed herein do not necessarily state or reflect those of the United States Government or any agency thereof.

This report has been reproduced directly from the best available copy.

Available to DOE and DOE contractors from the Office of Scientific and Technical Information, P. O. Box 62, Oak Ridge, TN 37831; prices available from (423) 576-8401.

Available to the public from the National Technical Information Service, U. S. Department of Commerce, 5285 Port Royal Road, Springfield, VA 22161. 
$\begin{array}{ll}\text { EXECUTIVE SUMMARY } & 1\end{array}$

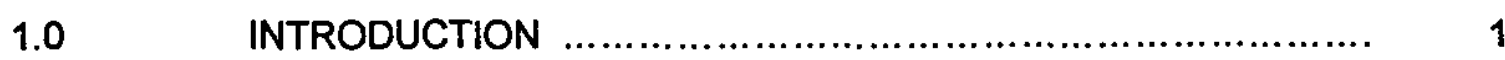

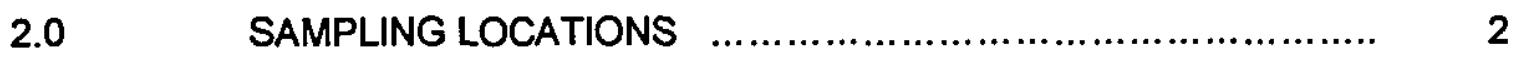

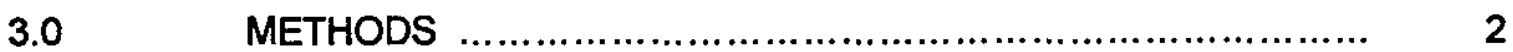

$3.1 \quad$ Sample Collection …........................................... 2

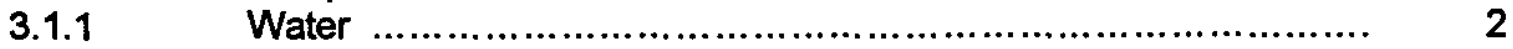

3.1.2 Sediment ........................................................ 5

3.2 Chemical Analyses …............................................. 5

3.2.1 Water ................................................................ 5

3.2.2 Sediment ........................................................ 5

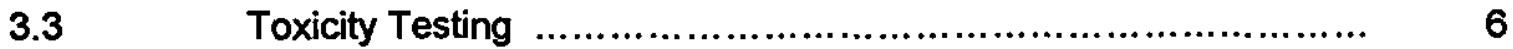

3.3.1 Water Toxicity Tests …............................................. 6

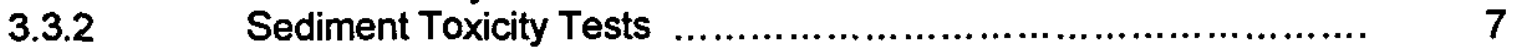

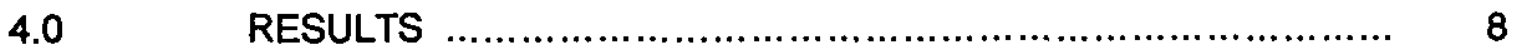

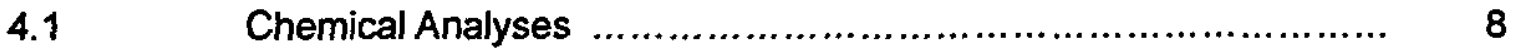

4.1.1 Water Chemistry ................................................... 8

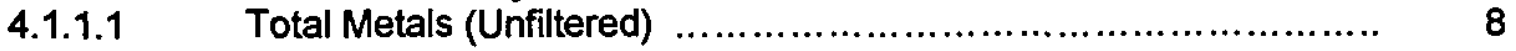

4.1.1.2 Dissolved Metals ..................................................... 9

4.1.2 Sediment Chemistry ................................................. 10

4.1.3 Comparison to Toxicity Reference Values ............................ 11

4.1.3.1 Surface Water ........................................................ 11

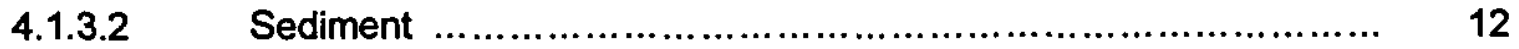

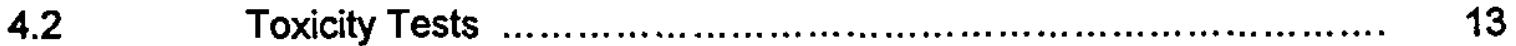

4.2.1 Water Toxicity Tests ….............................................. 13

4.2.2 Sediment Toxicity Tests …..................................... 13

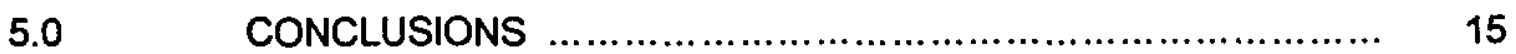

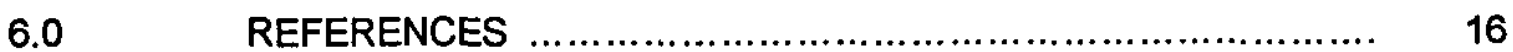

\section{Appendix Tables}

Appendix 1 Water Toxicity Test Reports

Appendix 2 Sediment Toxicity Test Reports

Appendix 3 Results of Statistical Analyses for Sediment Toxicity Tests, Using SRS Background Sediment as the Control 
Table 1 Analytical Methods and Method Detection Limits for CSBRP

Table 2 Analytical Methods and Method Detection Limits for Sediment Samples

Table 3 Test Conditions for Conducting a 7-day Definitive Water Toxicity Test with Ceriodaphnia dubia

Table 4

Test Conditions for Conducting a 10-day Sediment Toxicity Test with Hyalella azteca, following U.S. EPA Testing Protocol

Table 5 Results of Chemical Analyses of Unfiltered Water Samples Collected Near the CSBRP, January 1999.

Table 6

Results of Chemical Analyses of Filtered Water Samples Collected Near the CSBRP, January 1999.

Table 7

Results of Chemical Analyses of Sediment Samples Collected Near the CSBRP, January 1999.

Table 8 Comparison of CSBRP Water and Sediment Chemistry Data (January 1999) to TRVs

Table $9 \quad$ Results of Toxicity Tests Conducted on Water Samples from 4 Locations Near the Central Shops Buming Rubble Pit Waste Unit and an Unimpacted Reference Location, January, 1999

Table 10 Results of Toxicity Tests Conducted on Sediment Samples from 4 Locations Near the Central Shops Buming Rubble Pit Waste Unit and an Unimpacted Reference Location, January, 1999

Table 11 A Comparison of the Results of CSBRP Sediment Toxicity Tests to the Results from the Background Reference Sediment Toxicity Test

\section{List of Figures}

Page

Figure 1 Sampling Locations at the Central Shops Burning Rubble Pit .....

Figure 2 Location of Central Shops Burning Rubble Pit and Castor Bay ....

Figure 3 Results of Toxicity Tests on Water Samples Collected Near the CSBRP, January 1999. 


\section{EXECUTIVE SUMMARY}

The Central Shops Burning Rubble Pit Operable Unit consists of two inactive rubble pits (631-1G and 631-3G) that have been capped, and one active burning rubble pit $(631-2 G)$, where wooden pallets and other non-hazardous debris are periodically burned. The inactive rubble pits may have received hazardous materials, such as asbestos, batteries, and paint cans, as well as non-hazardous materials, such as ash, paper, and glass.

In an effort to determine if long term surface water flows of potentially contaminated water from the 631-1G, 631-3G, and 631-2G areas have resulted in an accumulation of chemical constituents at toxic levels in the vicinity of the settling basin and wetlands area, chemical analyses for significant ecological preliminary constituents of concern (pCOCs) were performed on aqueous and sediment samples. In addition, aquatic and sediment toxicity tests were performed in accordance with U.S. EPA methods (U.S. EPA 1989, 1994).

Based on the results of the chemical analyses, unfiltered water samples collected from a wetland and settling basins located adjacent to the CSBRP Operable Unit exceed Toxicity Reference Values (TRVs) for aluminum, barium, chromium, copper, iron, lead, and vanadium at one or more of the four locations that were sampled. The water contained very high concentrations of clay particles that were present as suspended solids. A substantial portion of the metals were present as filterable particulates, bound to the clay particles, and were therefore not biologically available. Based on dissolved metal concentrations, the wetland and settling basin exceeded TRVs for aluminum and barium. However, the background reference location also exceeded the TRV for barium, which suggests that this value may be too low, based on local geochemistry. The detection limits for both total and dissolved mercury were higher than the TRV, so it was not possible to determine if the TRV for mercury was exceeded. Dissolved metal levels of chromium, copper, iron, lead and vanadium were below the TRVs. Metal concentrations in the sediment exceeded the TRVs for arsenic, chromium, copper, and mercury but not for antimony and lead.

The results of the water toxicity tests indicated no evidence of acute toxicity in any of the samples. The results of the chronic toxicity tests indicated possible reproductive impairment at two locations. However, the results appear to be anomalous, since the toxicity was unrelated to concentration, and because the concentrations of pCOCs were similar in the toxic and the non-toxic samples. The results of the sediment toxicity tests indicated significant mortality in all but one sample, including the background reference sediment. When the results of the CSBRP sediment toxicity tests were statistically compared to the result from the background reference sediment, there was no significant mortality. These results suggest that the surface water and sediment at the CSBRP Operable Unit are not toxic to the biota that inhabit the wetland and the settling basin.

\subsection{INTRODUCTION}

The Central Shops Buming Rubble Pit (CSBRP) Operable Unit (OU) is comprised of two inactive buming rubble pits: Pits $631-1 \mathrm{G}$ and $631-3 \mathrm{G}$. Each pit may have received hazardous materials (e.g., asbestos, batteries and paint cans) along with non-hazardous materials (e.g., ash, paper, and glass) at various times from the 1950 s to the 1980 s. Waste possibly was burned periodically at Pit 631-1G. When burning activities ceased, waste material were disposed in the pits. When a pit reached capacity, it was capped with varying thicknesses of soil and abandoned. Pits 631-1G and 631-3G are located 
along the northem and westem sides of a single clearing that also contains the active buming area $(631-2 G)$. The inactive pits $(631-1 G$ and $631-3 G)$ are covered by tall grasses and weeds. The active burning area is unvegetated.

A settling basin and wetlands area are dominated by cattail (Typha spp.) and bulrush (Scirpus spp.) with scattered trees, including sycamore (Plantus occidentalis), wax myrtle (Myrica cerga), and black willow (Salix nigra). The settling basin has not been maintained adequately, allowing for invasion of wetland vegetation. Water levels fluctuate seasonally, or more often, depending on rainfall. The settling basin and the wetlands area drain into an unnamed, intermittent stream, which is also fed in part by stormwater runoff outfalls from Central Shops. Figure 1 identifies pits 631-1G and 631$3 G$, active bum area $631-2 G$, the settling basin, and the wetlands area.

In an effort to determine if long term surface water flows of potentially contaminated water from the $631-1 G, 631-3 G$, and $631-2 G$ areas have resulted in an accumulation of chemical constituents at toxic levels in the vicinity of the settling basin and wetlands area, chemical analyses for significant ecological preliminary constituents of concern (pCOCs) were performed on aqueous and sediment samples. In addition, aquatic and sediment toxicity tests were performed in accordance with U.S. EPA methods (U.S. EPA 1989, 1994).

The significant ecological pCOCs identified in the RFIRI with BRA for the Central Shops Buming/Rubble Pits (631-1G and 631-3G) (U) WSRC 1998) for the ponded area surface water include aluminum, barium, chromium, copper, iron, lead, mercury, and vanadium. The significant $\mathrm{pCOCs}$ for the sediments include antimony, arsenic, chromium, copper, mercury, and lead.

\subsection{SAMPLING LOCATIONS}

Water and sediment samples were collected from locations that were sampled during the RI/BRA characterization study (WSRC, 1998), including three locations in the settling basin, and one location in wetlands area (Figure 1). In addition, reference samples were collected from Castor Bay (Carolina Bay \#127) which is an unimpacted Carolina Bay, located approximately $2 \mathrm{~km}$ southeast of the CSBRP (Figure 2).

\subsection{METHODS}

\subsection{Sample Collection}

All water and sediment samples collected for chemical analyses were collected on January 11, 1999. EPA aquatic toxicity testing methods requires that three samples be collected for a 7-day test. The samples for aquatic toxicity testing were collected on January 11,13 , and 15 . EPA sediment toxicity testing methods require that one sample be collected for the 10-day test. These samples were collected on January 11, 1999.

\subsubsection{Water}

At all locations except CSBRP-45, water samples were collected by immersing approved sample bottles into the water to be sampled. At location CSBRP-45 the water was very shallow $(<2 \mathrm{~cm})$. Two pits, each approximately $20 \mathrm{~cm}$ deep were dug and allowed to fill and overflow for $>24$ hours. Samples were collected from the pits by dipping a clean 


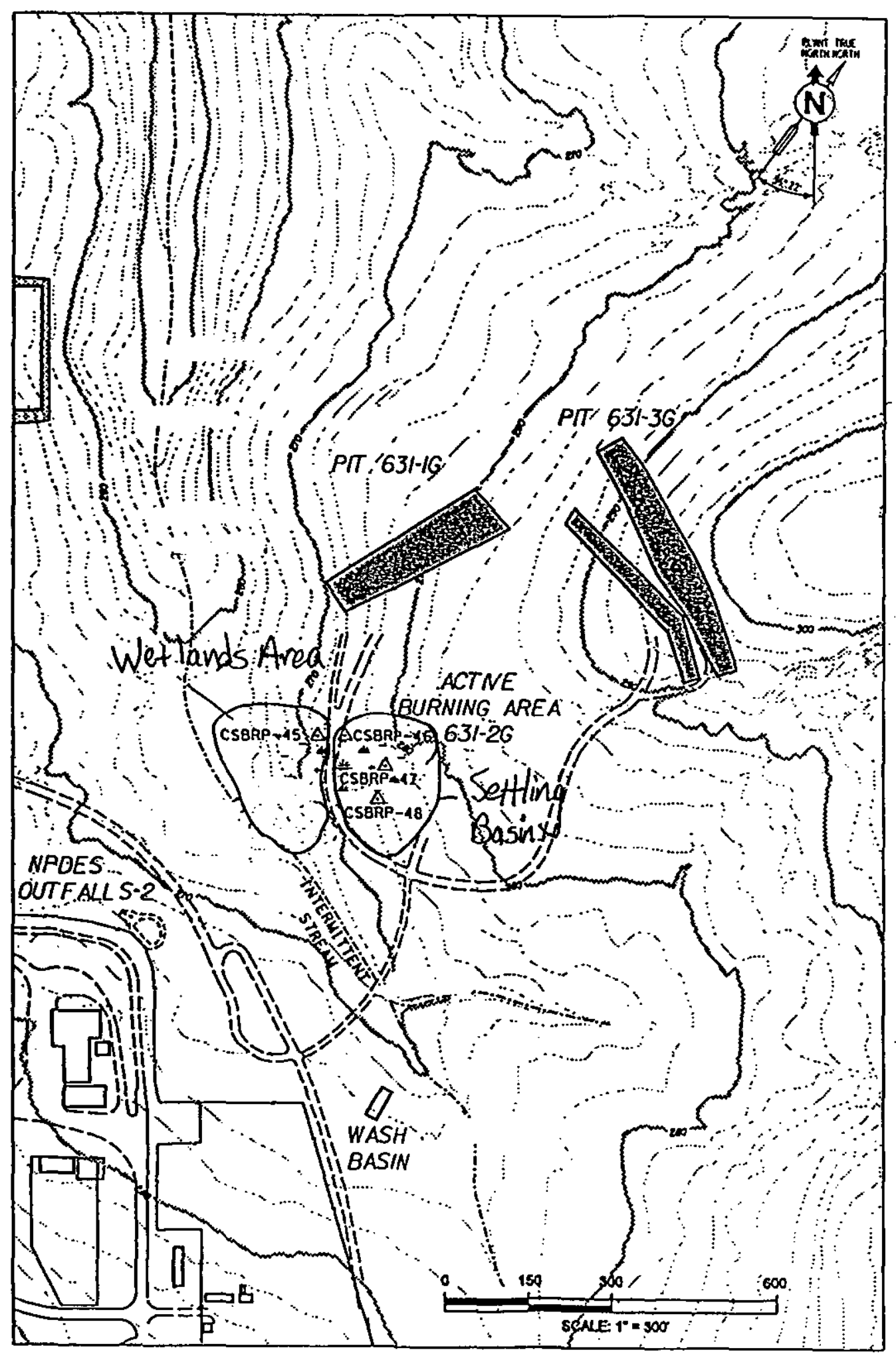

Figure 1. Sampling Locations at the Central Shops Buming Rubble Pit 


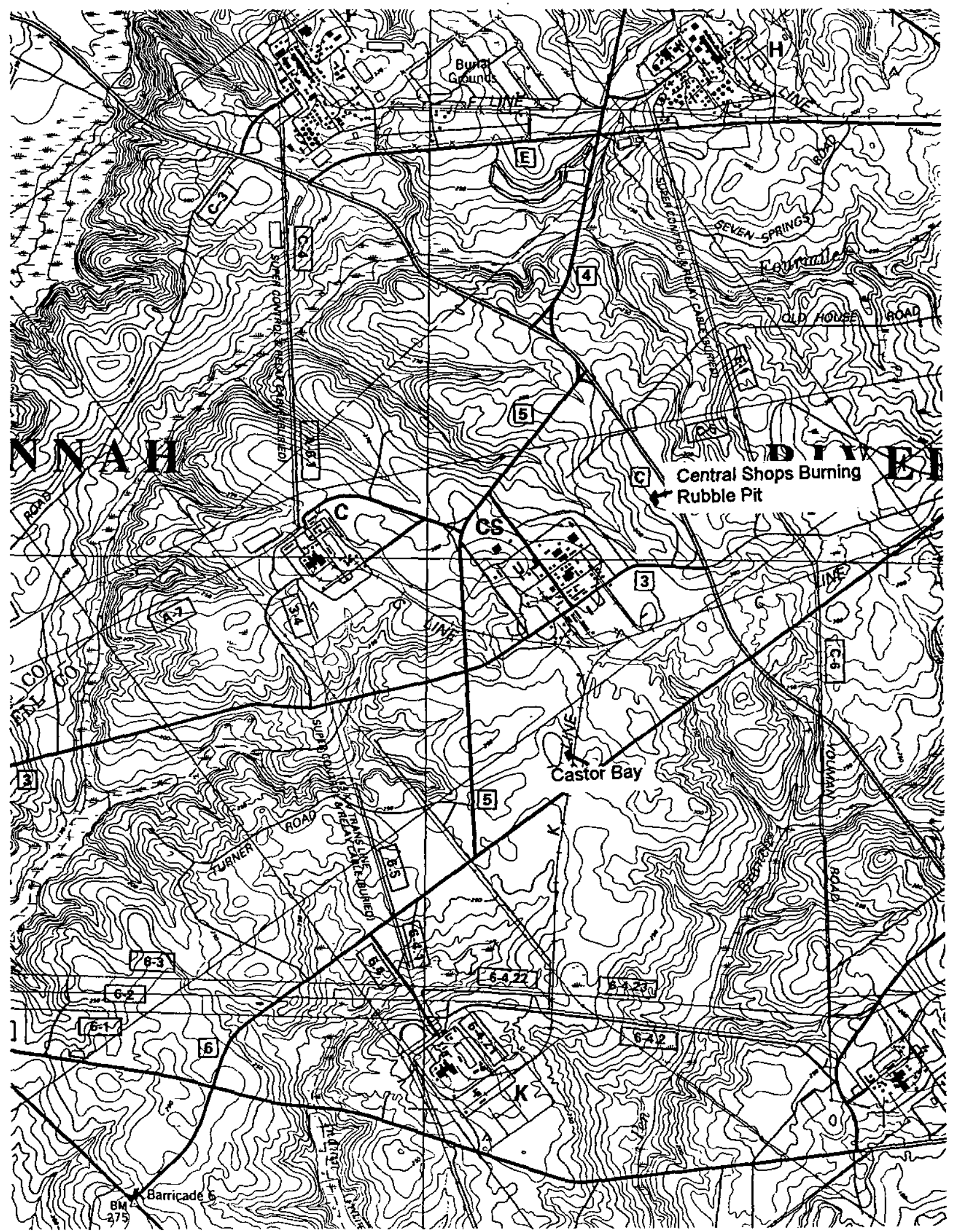

Figure 2. Location of Central Shops Burning Rubble Pit and Castor Bay 
nalgene beaker into the water and pouring the water into the sample bottles. All water samples were placed in coolers, iced, and transported to a certified laboratory for testing and analysis.

\subsubsection{Sediment}

Sediment samples were collected with a garden spade. To prevent the metal of the shovel blade from contacting the sediment, the entire blade of the shovel was covered with a polyethylene bag, and the top of the bag was secured with tape to the handle of the shovel. A new bag was used for each sampling location. The shovel blade was pushed into the sediment to its full depth and slowly brought to the surface of the overlying water. The sediment on the shovel blade was then scooped or poured into a polyethylene sample container. Samples were placed in a cooler, iced, and transported to a certified laboratory for testing and analysis.

\subsection{Chemical Analyses}

\subsubsection{Water}

Chemical analyses of the water samples were conducted by a certified laboratory (General Engineering Laboratory, Charleston, SC SCDHEC Certification \# 10120; GEL Mobile Lab Certification \# 02012001) using the methods specified in Table 1.

Table 1. Analytical Methods and Minimum Detection Limits for Water Samples

\begin{tabular}{lcrr} 
Analyte & Digestion Method & Analytical Method & \multicolumn{1}{c}{ SSMDL } \\
& & & $9.23 \mu \mathrm{g} / \mathrm{l}$ \\
\hline Aluminum & EPA3005A & EPA6020 & $0.386 \mu \mathrm{g} / 1$ \\
Barium & EPA3005A & EPA6020 & $6 \mu \mathrm{g} / \mathrm{l}$ \\
Hexavalent chromium & $\mathrm{N}^{*}$ & EPA7196 & $0.598 \mu \mathrm{g} / 1$ \\
Chromium & EPA3005A & EPA6020 & $0.254 \mu \mathrm{g} / 1$ \\
Copper & EPA3005A & EPA6020 & $14 \mu \mathrm{g} / 1$ \\
Iron & EPA3005A & EPA6020 & $0.035 \mu \mathrm{g} / 1$ \\
Mercury (off-site lab) & $\mathrm{N}^{*}$ & EPA7470 & $0.1 \mu \mathrm{g} / 1$ \\
Mercury (on-site lab) & $\mathrm{N}^{*}$ & EPA7470 & $0.311 \mu \mathrm{g} / \mathrm{l}$ \\
Lead & EPA3005A & EPA6020 & $2.94 \mu \mathrm{g} / 1$
\end{tabular}

$N$ - none

* Sample Specific Method Detection Limit

The water in the settling basin was very turbid at the time of sampling. In order to differentiate between metals that were present as particulates (bound to soil particles) and dissolved, analyses were performed on unfiltered water samples and water samples that were filtered through a $0.45 \mu$ filter. Results for the metal analyses are reported as total (unfiltered) and dissolved (filtered). In interpreting the results, if a result was less than the detection limit, $50 \%$ of the sample specific method detection limit (ssmdl) was reported.

\subsubsection{Sediment}

Chemical analyses of the sediment samples were conducted by a certified laboratory (General Engineering Laboratory, Charleston, SC SCDHEC Certification \# 10120; GEL 
Mobile Lab Certification \# 02012001) using the methods specified in Table 2 . In interpreting the results, if a result was less than the detection limit, $50 \%$ of the sample specific method detection limit (ssmdl) was reported.

Table 2. Analytical Methods and Minimum Detection Limits for Sediment Samples

\begin{tabular}{|l|l|l|l|}
\hline Analyte & Digestion Method & Analytical Method & SSMDL \\
\hline Antimony & EPA3050B & EPA6020 & 9.86 to $2335.7 \mu \mathrm{g} / \mathrm{kg}$ \\
\hline Arsenic & EPA3050B & EPA6020 & 81.4 to $665 \mu \mathrm{g} / \mathrm{kg}$ \\
\hline $\begin{array}{l}\text { Hexavalent } \\
\text { chromium }\end{array}$ & EPA3060A & EPA7196A & 8 to $182 \mu \mathrm{g} / \mathrm{kg}$ \\
\hline Chromium & EPA3050B & EPA6020 & 100.8 to $825 \mu \mathrm{g} / \mathrm{kg}$ \\
\hline Copper & EPA3050B & EPA6020 & 72.35 to $591 \mu \mathrm{g} / \mathrm{kg}$ \\
\hline Mercury & $\mathrm{N}^{*}$ & EPA7471A & 2.53 to $6.36 \mu \mathrm{g} / \mathrm{kg}$ \\
\hline Lead & EPA3050B & EPA6020 & 55.1 to $451 \mu \mathrm{g} / \mathrm{kg}$ \\
\hline
\end{tabular}

*N-None

* Sample Specific Method Detection Limit. The SSMDL for sediment samples is related to sample mass and concentration, and therefore varies among samples

\subsection{Toxicity Testing}

\subsubsection{Water Toxicity Tests}

Chronic (7-day) definitive toxicity tests were conducted on the water samples using Ceriodaphnia dubia as the test species. All tests were performed by a certified laboratory (ETT Environmental, Greenville, SC, SCDHEC Certification \# 23104001) in strict accordance with U.S. EPA methods (Weber et al., 1989). Test conditions are summarized in Table 3.

Table 3. Test Conditions for Conducting a 7-day Definitive Water Toxicity Test with Ceriodaphnia dubia

\begin{tabular}{ll} 
Parameter & Conditions \\
\hline Test type & Static renewal \\
Temperature & $25 \pm 1^{\circ} \mathrm{C}$ \\
Light quality & Ambient laboratory illumination \\
Light intensity & $50-100$ foot candies \\
Photoperiod & $16 \mathrm{~L}: 80$ \\
Test chamber size & $30 \mathrm{ml}$ \\
Test solution volume & $15 \mathrm{ml}$ \\
Renewal of test water & Daily \\
Age of test organisms & Less than $24 \mathrm{~h}$ at start of test; all released within a $12 \mathrm{~h}$ period \\
\# neonates/test chamber & 1 \\
\# Neonates/concentration & 10 \\
Feeding regime & $0.1 \mathrm{ml} \mathrm{YCT}$ and algal suspension/test chamber/day \\
Aeration & None \\
Dilution water & Diluted mineral water \\
Number of dilutions & 5 and a control
\end{tabular}




\subsubsection{Sediment Toxicity Tests}

10-day survival toxicity tests were conducted on the sediment samples using the amphipod, Hyalella azteca as the test species. All tests were performed by a laboratory certified to perform biological testing (ETT Environmental, Greenville, SC; SCDHEC Certification \#23104001); however, SCDHEC currently has no recommended protocols for sediment toxicity tests. The testing was performed following EPA Test Method 100.1, Hyalella azteca 10-d Survival Test for Sediments (U.S. EPA, 1994). Test conditions are summarized in Table 4. The reference sediment used for the toxicity tests was collected from Resurrection Creek, Greenville County, SC. ETT Environmental routinely uses sediment from this location as a control sediment and has demonstrated that it consistently meets the survival criterion for a control sediment.

Table 4. Test Conditions for Conducting a 10-day Sediment Toxicity Test with Hyalella azteca, following U.S. EPA Testing Protocol

Parameter Test type

Temperature

Light quality

Light intensity

Photoperiod

Test chamber

Sediment volume

Overlying water volume

Water renewal

Age of organisms

Number of organisms

per chamber

Number of replicates

per treatment

Feeding

Aeration

Overlying water

Overlying water quality parameters

Test duration

Endpoint

Test acceptability

\section{Conditions}

Whole sediment toxicity test with renewal of overlying water

$23 \pm 1^{\circ} \mathrm{C}$

Wide-spectrum fluorescent lights

500 to 1000 lux

16L:80

$300 \mathrm{ml}$ beaker

$100 \mathrm{ml}$

$175 \mathrm{ml}$

2 volume additions/day

7 to 14 days at start of test

.10

8

YCT food, 1.5 milday/test chamber

None, unless DO drops below $40 \%$ of saturation

Surface water

Hardness, alkalinity, conductivity, pH, and ammonia at beginning and end of test; temperature and DO daily

10 days

Survival

Control survival $\geq 80 \%$ 


\subsection{RESULTS}

\subsection{Chemical Analyses}

\subsubsection{Water Chemistry}

\subsubsection{Total Metals (Unfiltered)}

The results of the unfiltered water chemistry analyses are presented in Table 5. The results indicate that the three samples collected from the settling basin (CSBRP-46, 47, and 48 ) were extremely turbid, with turbidities ranging from 259 to 342 NTU. CSBRP-45 was much less turbid (15.2 NTU), and the background surface water (BKD-SW), had low turbidity (7.97 NTU). The high turbidity of the settling basin was not related to the suspension of sediment during sampling activities. The settling basin was very turbid prior to sampling, and visual observations of the settling basin on two earlier occasions (during the fall of 1998 and on January 6,1999 ) indicated that the water in the basin was turbid at these times, as well. The high turbidity is probably the result of continued runoff from the active burning rubble pit (631-2G). Several acres of soil around the active burning area serve as a buffer area to prevent fire from spreading to the surrounding vegetated areas. The soil of the buffer area is exposed (devoid of vegetation) and the soil appears to have a high clay content. Although the burning rubble pit is relatively flat, drainage from the burning rubble pit flows in the direction of the settling basin, and the clays present in the runoff are likely to be responsible for the high turbidity in the settling basin.

Table 5. Results of Chemical Analyses of Unfiltered Water Samples Collected Near the CSBRP, January 1999.

Location

Analyte

Units BKD-SW CSBRP-45 CSBRP-46 CSBRP-47 CSBRP-48

\begin{tabular}{|c|c|c|c|c|c|c|}
\hline Total Aluminum & $\mu \mathrm{g} / \mathrm{h}$ & 80.8 & 2030 & 18600 & 21800 & 171 \\
\hline Total Barium & $\mu g / 1$ & 18.1 & 68.1 & 65.3 & 69.6 & \\
\hline Total Chromium 6 & $\mu \mathrm{g} / \mathrm{l}$ & bdl (3) & bdl (3) & 20 & bdl (3) & \\
\hline Total Chromium & $\mu g / l$ & bdl $(0.3)$ & 3.52 & 31.9 & 38 & \\
\hline Total Copper & $\mu \mathrm{g} / \mathrm{l}$ & 3.71 & 5.42 & 19.1 & 20.3 & \\
\hline Total Iron & $\mu g /$ & 679 & 1320 & 12200 & 13100 & \\
\hline Total Mercury* & $\mu \mathrm{g} / \mathrm{l}$ & bdl (0.017) b & bdl $(0.017)$ & bdl (0.017) & bdl $(0.017)$ & bo \\
\hline Total Mercury ** & $\mu g /$ & bdl (0.05) & bdl $(0.05)$ & bdi (0.05) & bdl (0.05) & 10. \\
\hline Total Lead & $\mu g / 1$ & 0.425 & 1.13 & 9.5 & 10.8 & \\
\hline Total Vanadium & $\mu g / l$ & bdl (1.47) & 5.14 & 27.9 & 29.6 & \\
\hline Turbidity & NTU & $\begin{array}{l}7.97 \\
\text { reported } \\
\text { ratory }\end{array}$ & 15.2 & 259 & 342 & \\
\hline
\end{tabular}

Because of the high turbidity present in CSBRP-46, 47, and 48, the metals data must be interpreted very cautiously. In most surface waters, turbidity is related to the amount of suspended matter present in the water, and in general, most of the suspended matter consists of fine clays. Clays are comprised of largely of iron and aluminum silicates, and therefore contain high concentrations of iron and aluminum, as well as lesser amounts of other metals that occur naturally in the earth's crust. Cationic metals present in water 
are attracted to the negatively charged clay particles and are readily adsorbed to the surface of the clay particles. Adsorbed metals generally have very limited bioavailability, since they are bound tightly to clay particles that are too large to pass across cell membranes, and therefore cannot be taken up by biota. High turbidity can have adverse biological effects, both directly, by clogging the gills of aquatic organisms, and indirectly, by limiting visibility, and thus limiting prey capture. High turbidity can also limit the depth to which light will penetrate the water, which can reduce primary productivity, thus reducing food availability for organisms that feed on phytoplankton.

As would be expected in very turbid water, the concentrations of total aluminum in the water samples collected from CSBRP-46, 47, and 48 were extremely high, ranging from 17,100 to $21,800 \mu \mathrm{g} /$, and iron concentrations were also very high, ranging from 10,900 to $13,100 \mu \mathrm{g} / \mathrm{l}$ (Table 5). Iron and aluminum were also somewhat elevated at CSBRP-45 (1320 and $2030 \mu \mathrm{g} / \mathrm{l})$, and much lower at the background reference location. The high concentrations of iron and aluminum at the CSBRP locations, along with the high turbidity, indicate that the turbidity is due to suspended clays, which will greatly influence the concentrations of other metals present in the unfiltered water. From a biological and toxicological standpoint, it is reasonable to focus the remainder of the discussion on the results of the metal analyses conducted on filtered samples, which will give a more meaningful indication of the potential for ecological risk.

\subsubsection{Dissolved Metals}

Table 6 presents the results of the metal analyses performed on filtered water samples.

Table 6. Results of Chemical Analyses of Filtered Water Samples Collected Near the CSBRP, January 1999.

Location

\begin{tabular}{|c|c|c|c|c|c|c|}
\hline Analyte & Units & KD-SW & BRP-45 & BRP-46 & $B R P-47$ & SBRP-48 \\
\hline Dissolved Aluminum & $\mu \mathrm{g} / \mathrm{h}$ & 23.3 & 49.2 & 1160 & 807 & 1240 \\
\hline Dissolved Barium & $\mu \mathrm{g} / \mathrm{l}$ & 13.1 & 64.7 & 32.6 & 30.9 & 42.7 \\
\hline Dissolved Chromium 6 & $\mu \mathrm{g} / \mathrm{l}$ & bdl (3) & bdl (3) & bdl (3) & bdl (3) & bdl (3) \\
\hline Dissolved Chromium & $\mu g / l$ & bdl (0.3) & bdl $(0.97)$ & 4 & 5.57 & 4.85 \\
\hline Dissolved Copper & $\mu g / 1$ & 0.892 & 1.35 & 3.8 & 3.4 & 4.1 \\
\hline Dissolved Iron & $\mu g / l$ & 57.7 & 142 & 494 & 338 & 49 \\
\hline Dissolved Mercury* & $g /$ & 0.191 & 018) & 0.183 & 0.142 & 0.1 \\
\hline Dissolved Mercury** & $\mu g / 1$ & bdl $(0.05)$ & bdl $(0.05)$ & bdl (0.05) & bdl $(0.05)$ & $(0.05$ \\
\hline Dissolved Lead & $\mu g / 1$ & bdl $(0.156)$ & bdl $(0.156)$ & 0.505 & 0.533 & 0.48 \\
\hline Dissolved Vanadium & $\mathrm{lg} / 1$ & bdl (1.47) & bdl (1.47) & bdl (1.47) & bdl (1.47) & bdl (1.47 \\
\hline
\end{tabular}

bdl - below detection limit $50 \%$ of ssmdl is reported

"Data from GEL's Charleston Laboratory

*Data from GEL's mobile laboratory at SRS

Concentrations of dissolved aluminum at the CSBRP locations ranged from $49.2 \mu \mathrm{g} / \mathrm{l}$ at CSBRP -45 to $1240 \mu \mathrm{g} /$ at CSBRP-48, as compared to $23.3 \mu \mathrm{g} / \mathrm{l}$ at the background reference location (Table 6). Dissolved barium ranged from 30.9 to $42.7 \mu \mathrm{g} /$ in the settling basin, and was $64.7 \mu \mathrm{g} / \mathrm{in}$ the wetland and $13.1 \mu \mathrm{g} / \mathrm{l}$ in the sample from the background reference location. Dissolved chromium was below detection at the 
background reference location and the wetland and ranged from 4.0 to $5.57 \mu \mathrm{g} /$ in the settling basin. Dissolved copper was relatively low at all locations, ranging from 0.892 $\mu \mathrm{g} / \mathrm{l}$ at the background reference location to $4.18 \mu \mathrm{g} / \mathrm{l}$ at CSBRP-48. Dissolved iron ranged from $57.7 \mu \mathrm{g} / \mathrm{l}$ at the background location to $496 \mu \mathrm{g} / \mathrm{l}$ at CSBRP-48. Dissolved mercury was higher at the background reference location $(0.191 \mu \mathrm{g} / \mathrm{l})$ than at any of the CSBRP locations (bdl to $0.183 \mu \mathrm{g} /$ ) $)$. However, the mercury data are somewhat suspect, since total mercury was not detected at any location, but dissolved mercury was measured in four of the five samples. No total or dissolved mercury was detected in the duplicate samples that were analyzed at an on-site mobile laboratory (Table 6).

Although the detection limits of the on-site laboratory were higher $(0.05 \mu \mathrm{g} / \mathrm{vs} .0 .017$ $\mu \mathrm{g} /$ for the off-site laboratory), no dissolved mercury was detected in any of the samples analyzed at the on-site laboratory, while concentrations far in excess of $0.05 \mu \mathrm{g} / \mathrm{l}$ were reported from the off-site laboratory. It appears likely that the samples analyzed at the off-site laboratory were contaminated with mercury during the filtration process.

Dissolved lead was not detected at the background reference location or the wetland, but ranged from 0.483 to $0.533 \mu \mathrm{g} / \mathrm{l}$ in the settling basin. Hexavalent chromium (chromium 6) and vanadium were below detection in all of the filtered samples.

CSBRP-45, which was located in the wetland, had lower concentrations of all pCOC dissolved metals than did the samples collected from the settling basin. However, CSBRP-45 had a higher concentration of barium than the samples collected from the settling basin, which suggest that this constituent probably originated in the inactive burning rubble pits, rather than at the active burning area adjacent to the settling basin. Based on these results, it appears likely that barium is the only pCOC present in the filtered water samples that originated from the inactive buming rubble pits. The remaining constituents probably originate from the active burning rubble pit adjacent to the settling basin, since concentrations in the settling basin have higher concentrations of all of the other pCOCs than does the wetland.

\subsubsection{Sediment Chemistry}

The sediment chemistry data are summarized in Table 7. Antimony was below detection in all of the samples. Arsenic was extremely high in all of the CSBRP sediment samples, ranging from 46,500 to $86,900 \mu \mathrm{g} / \mathrm{kg}$, as compared to $1794 \mu \mathrm{g} / \mathrm{kg}$ at the background reference location. Hexavalent chromium (chromium 6) was relatively low at all locations, ranging from below detection at two CSBRP locations to $4650 \mu \mathrm{g} /$ at the background reference location. However, total chromium was greatly elevated in the CSBRP sediments, ranging from $84,400 \mu \mathrm{g} / \mathrm{kg}$ to $101,000 \mu \mathrm{g} / \mathrm{kg}$, as compared to 16,157 $\mu \mathrm{g} / \mathrm{kg}$ at the background reference location. Mercury was present in all of the CSBRP sediments $(65.8$ to $195 \mu \mathrm{g} / \mathrm{kg}$ ), but was not detected in the background reference sediment. Lead concentrations in the CSBRP sediments $(28,200$ to $36,700 \mu \mathrm{g} / \mathrm{kg})$ were fairly similar to that of the background reference sediment $(33,137 \mu \mathrm{g} / \mathrm{kg})$.

The wetland (CSBRP-45) had higher concentrations of arsenic, chromium, and copper than the settling basin locations. These three metals are present in wood that has been pressure-treated with chromated copper arsenate to retard decay. In appears that these metals have either entered the wetland from the inactive seepage basins, or more likely, that they have accumulated in the soil, as water from the settling basin flowed into the wetland over the course of many years. 
Table 7. Results of Chemical Analyses of Sediment Samples Collected Near the CSBRP, January 1999.

\begin{tabular}{lrrrrrr} 
& & \multicolumn{7}{c}{ Location } \\
Analyte & Units & \multicolumn{1}{c}{ BKD-SW } & CSBRP-45 & CSBRP-46 & CSBRP-47 & CSBRP-48 \\
\hline Antimony & $\mu g / k g$ & bdl $(3.43)$ & bdl (524) & bdl (1122) & bdl (1168) & bdl (959) \\
Arsenic & $\mu g / k g$ & 1794 & 86900 & 78300 & 50800 & 46500 \\
Chromium 6 & $\mu g / k g$ & 4650 & 733 & bdl $(88)$ & 485 & bdl (73) \\
Chromium & $\mu g / k g$ & 16157 & 101000 & 95400 & 84400 & 85500 \\
Copper & $\mu g / k g$ & 8529 & 115000 & 73900 & 63700 & 59800 \\
Mercury & $\mu g / k g$ & bdl (2.12) & 83.6 & 195 & 119 & 65.8 \\
Lead & $\mu g / k g$ & 33137 & 28200 & 32700 & 33900 & 36700
\end{tabular}

bdl - below detection limit. $50 \%$ of ssmdl is reported

\subsubsection{Comparison to Toxicity Reference Values}

Table 8 compares the chemical concentrations of the water (total and dissolved) and sediment samples from the CSBRP settling basin and wetlands to the Toxicity Reference Values (TRVs) listed in the Baseline Risk Assessment (WSRC, 1998).

\subsubsection{Surface Water}

With the exception of barium, concentrations of the pCOCs in water from the reference location (BKD-SW) were all below the TRVs. Total and dissolved concentrations of barium at BKD-SW were 18 and $13 \mu \mathrm{g} / \mathrm{l}$, respectively (Table 8 ). These results suggest that the TRV for barium may be unrealistically low, based on local geochemistry at the Savannah River Site.

Based on total aluminum, all of the CSBRP locations exceeded the TRV for aluminum; based on dissolved concentrations, all but CSBRP- 45 exceeded the TRV.

Based on total chromium, all of the CSBRP locations except CSBRP-45 exceeded the TRV for chromium; based on dissolved concentrations, none of the locations exceeded the TRV.

Based on total copper, all of the CSBRP locations exceeded the TRV for copper; based on dissolved concentrations, all of the locations were below the TRV.

Based on total iron, all of the CSBRP locations exceeded the TRV for iron; based on dissolved concentrations, all of the locations were below the TRV.

Based on total mercury, all of the CSBRP locations were below the detection limit for mercury. However, the detection limit $(0.017 \mu \mathrm{g} / \mathrm{l})$ is greater than the TRV $(0.0028 \mu \mathrm{g} / \mathrm{l})$, so it is not possible to determine if total mercury concentrations at the CSBRP actually exceed the TRV. Based on dissolved mercury concentrations from GEL's Charleston Laboratory, three of the four CSBRP locations exceeded the TRV for mercury, as did the reference location. Based on data from GEL's on-site mobile laboratory, none of the CSBRP locations exceeded the TRV for mercury. However, the mercury detection limits 
Table 8. Comparison of CSBRP Water and Sediment Chemistry Data (January 1999) to Toxicity Reference Values (TRVs)

\begin{tabular}{|c|c|c|c|c|c|c|}
\hline & $\begin{array}{l}\text { TRV } \\
(\mu g / L) \text { for } \\
\text { Water }\end{array}$ & CSBRP-45 & CSBRP-46 & CSBRP 47 & CSBRP-48 & BKD-SW \\
\hline Aluminum & 87 & $\begin{array}{l}\text { T } 2030^{*} \\
\text { D } 49\end{array}$ & $\begin{array}{l}\text { T18,600* } \\
\text { D } 1160^{*}\end{array}$ & $\begin{array}{l}\text { T } 2,1800^{*} \\
\text { D } 807^{*}\end{array}$ & $\begin{array}{l}\text { T } 17,100^{*} \\
\text { D } 1240^{*}\end{array}$ & $\begin{array}{l}\text { T } 81 \\
\text { D } 23\end{array}$ \\
\hline Barium & 3.9 & $\begin{array}{l}\text { T 68* } \\
\text { D 65* }\end{array}$ & $\begin{array}{l}\text { T 65* } \\
\text { D } 33^{*}\end{array}$ & $\begin{array}{l}\text { T 70* } \\
\text { D 31* }\end{array}$ & $\begin{array}{l}\text { T 70* } \\
\text { D 43* }\end{array}$ & $\begin{array}{l}\text { T 18* } \\
\text { D } 13^{*}\end{array}$ \\
\hline Chromium & 11 & $\begin{array}{l}T 4 \\
D<1\end{array}$ & $\begin{array}{l}\text { T } 32^{*} \\
\text { D } 4\end{array}$ & $\begin{array}{l}\text { T 38* } \\
\text { D } 6\end{array}$ & $\begin{array}{l}\text { T 29* } \\
\text { D } 5\end{array}$ & $\begin{array}{l}T<0.3 \\
D<0.3\end{array}$ \\
\hline Copper & 6.18 & $\begin{array}{l}\text { T } 5.4^{*} \\
\text { D } 1.4\end{array}$ & $\begin{array}{l}\text { T 19.1* } \\
\text { D } 3.8\end{array}$ & $\begin{array}{l}\text { T } 20.3^{*} \\
\text { D } 3.4\end{array}$ & $\begin{array}{l}\text { T } 19^{*} \\
\text { D } 4.2\end{array}$ & $\begin{array}{l}\text { T } 3.7 \\
\text { D } 0.9\end{array}$ \\
\hline Iron & 1000 & $\begin{array}{l}\text { T } 1320^{*} \\
\text { D } 142\end{array}$ & $\begin{array}{l}\text { T } 12,200^{*} \\
\text { D } 494\end{array}$ & $\begin{array}{l}\text { T } 13,100^{*} \\
\text { D } 338\end{array}$ & $\begin{array}{l}\text { T } 10,900^{*} \\
\text { D } 496\end{array}$ & $\begin{array}{l}\text { T } 679 \\
\text { D } 58\end{array}$ \\
\hline Lead & 1.21 & $\begin{array}{l}T 1.1 \\
D<02\end{array}$ & $\begin{array}{l}\text { T } 9.5^{*} \\
D 0.5\end{array}$ & $\begin{array}{l}T 10.8^{*} \\
\text { D } 0.5\end{array}$ & $\begin{array}{l}\text { T } 9.2^{*} \\
\text { D } 0.5\end{array}$ & $\begin{array}{l}T 0.4 \\
D<0.2\end{array}$ \\
\hline $\begin{array}{l}\text { Mercury* } \\
\text { Charleston Lab } \\
\text { Mercury } \\
\text { Mobile Lab } \\
\text { Vanadium }\end{array}$ & $\begin{array}{c}0.0028 \\
0.0028 \\
20\end{array}$ & $\begin{array}{l}T \text { bdl }(0.017) \\
D \text { bdl }(0.018) \\
T \text { bdl }(0.05) \\
D \text { bdl }(0.05) \\
T 5 \\
D<1.5\end{array}$ & $\begin{array}{l}\text { T bdl }(0.017) \\
\text { D } 0.183^{*} \\
\text { T bdl }(0.05) \\
\text { D bdl }(0.05) \\
T \text { 2 } 28^{*} \\
D<1.5\end{array}$ & $\begin{array}{l}T \text { bdl }(0.017) \\
D \quad 0.142^{*} \\
T \text { bdl }(0.05) \\
D \text { bdl }(0.05) \\
T 30^{*} \\
D<1.5\end{array}$ & $\begin{array}{l}\text { T bdl }(0.017) \\
D \quad 0.116^{*} \\
T \text { bdl }(0.05) \\
D \text { bdl }(0.05) \\
T 24^{*} \\
D<1.5\end{array}$ & $\begin{array}{l}T \text { bdl }(0.017) \\
D \quad 0.191^{*} \\
T \text { bdl }(0.05) \\
D \text { bdl }(0.05) \\
T<1.5 \\
D<1.5\end{array}$ \\
\hline
\end{tabular}

\begin{tabular}{|c|c|c|c|c|c|c|}
\hline Arsenic & $\begin{array}{c}\text { TRV (mg/kg) } \\
\text { for Sediment } \\
8.2\end{array}$ & $\begin{array}{c}\text { CSBRP-45 } \\
86.9^{\star}\end{array}$ & $\begin{array}{c}\text { CSBRP-46 } \\
78.3^{*}\end{array}$ & $\begin{array}{c}\text { CSBRP-47 } \\
50.8^{*}\end{array}$ & $\begin{array}{c}\text { CSBRP-48 } \\
46.5^{*}\end{array}$ & $\begin{array}{c}\text { BKD-SED } \\
1.8\end{array}$ \\
\hline Antimony & 2.0 & $<0.5$ & $<1.1$ & $<1.2$ & $<1.0$ & $<0.003$ \\
\hline Chromium & 81.0 & $101.0^{*}$ & $95.4^{*}$ & $84.4^{*}$ & $85.5^{*}$ & 16.2 \\
\hline Copper & 34.0 & $115^{*}$ & $73.9^{*}$ & $63.7^{*}$ & $59.8^{*}$ & 8.5 \\
\hline Lead & 46.7 & 28.2 & 32.7 & 33.9 & 36.7 & 33.1 \\
\hline Mercury & 0.15 & 0.0836 & $0.195^{*}$ & $0.119^{*}$ & 0.0658 & bdl (0.002) \\
\hline
\end{tabular}

$T=$ Total; $D=$ Dissolved

*Value exceeds TRV

**Mercury data from both laboratories is presented, since the dissolved mercury data from the Charleston data is suspect.

of both laboratories were greater than the TRV (Table 8), so it is not possible to determine if dissolved mercury concentrations at the CSBRP actually exceed the TRV.

Based on total lead, three of the four CSBRP locations exceeded the TRV for lead; based on dissolved concentrations, all of the locations were below the TRV.

Based on total vanadium, all but CSBRP-45 exceeded the TRV for vanadium; based on dissolved concentrations, all of the locations were below the TRV.

\subsubsection{Sediment}

Concentrations of the PCOCs in sediment from the reference location (BKD-SED were all below the TRVs (Table 8 ). All of the CSBRP locations had sediment concentrations of arsenic, chromium, and copper that were in excess of the TRVs. Two CSBRP locations had mercury concentrations in the sediment that exceeded the TRV. At all locations, antimony and lead were below the TRVs. 


\subsection{Toxicity Tests}

\subsubsection{Water Toxicity Tests}

The results of the toxicity tests are summarized in Table 9; detailed results are presented in Appendix 1. The results indicate that none of the locations that were sampled showed any evidence of acute toxicity. No Observed Effect Concentrations (NOEC's) for survival were all $>100 \%$ effluent, which indicates that exposure to the water did not result in significant mortality. The results of the chronic tests indicate that two of the locations ( 47 and 48 ) showed no evidence of chronic toxicity, as measured by reproductive impairment. Two locations (45 and 46) did show evidence of chronic toxicity, with NOEC's of $6.3 \%$ and $<6.3 \%$, respectively. The results of these two tests are highly unusual because there is little increase in toxicity with increasing concentrations of effluent (see Figure 3). The suppression of reproduction, although statistically significant, was relatively small, and may be a statistical anomaly. In general, if a water sample is toxic, there is a substantial decrease in reproduction with increasing concentration. This conclusion is further substantiated by the water chemistry data, which indicates that with the exception of barium, CSBRP-45 had much lower concentrations of the pCOCs than did the samples from the settling basin. Similarly, pCOC concentrations in water from CSBRP-46 in most instances were lower than those found at the other two settling basin locations. These results strongly suggest that the pCOCs were not responsible for the observed toxicity, and that the chronic toxicity was probably an anomaly. Undiluted water from the reference location (BKD-SW-1) was chronically toxic (NOEC of $50 \%$ ). It is very likely that the toxicity at the reference location was due to low hardness. Total calcium at the background reference location was less than $1 \mathrm{mg} /(786 \mu \mathrm{g} /$, which is very low). Ceriodaphnia dubia does not reproduce well in extremely soft water.

Table 9. Results of Toxicity Tests Conducted on Water Samples from 4 Locations Near the Central Shops Burning Rubble Pit Waste Unit and an Unimpacted Reference Location, January, 1999

Location

CSBRP-46-02-R
CSBRP-47-02-R
CSBRP-48-02-R
CSBRP-45-02-R
BKD-SW-1

Survival

LOEC

$>100 \%$

$>100 \%$

$>100 \%$

$>100 \%$

$>100 \%$
Reproduction

$\begin{array}{ll}\text { NOEC } & \text { LOEC } \\ <6.3 \% & 6.3 \% \\ >100 \% & >100 \% \\ >100 \% & >100 \% \\ 6.3 \% & 12.5 \% \\ 50 \% & 100 \%\end{array}$

\subsubsection{Sediment Toxicity Tests}

The results of the sediment toxicity tests are summarized in Table 10; detailed results are presented in Appendix 2. The results indicate that, with the exception of CSBRP-46, all of the sediments, including the unimpacted reference location (BKD-SED-1) had significant mortality as compared to the Control Sediment. However, if the results of the CSBRP sediment toxicity tests are statistically compared to the results from the background reference sediment, there was no significant reduction in survival 
Effluent Conc. vs. Reproduction

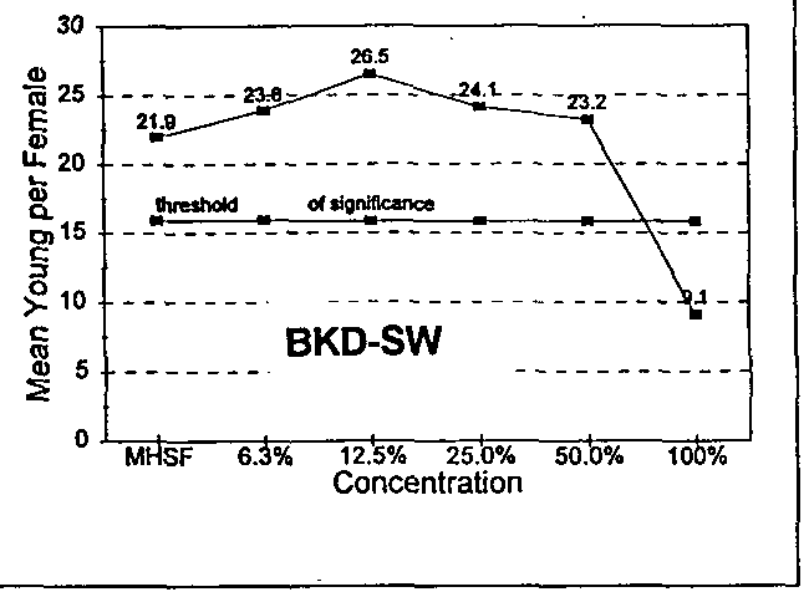

Effluent Conc. vs. Reproduction

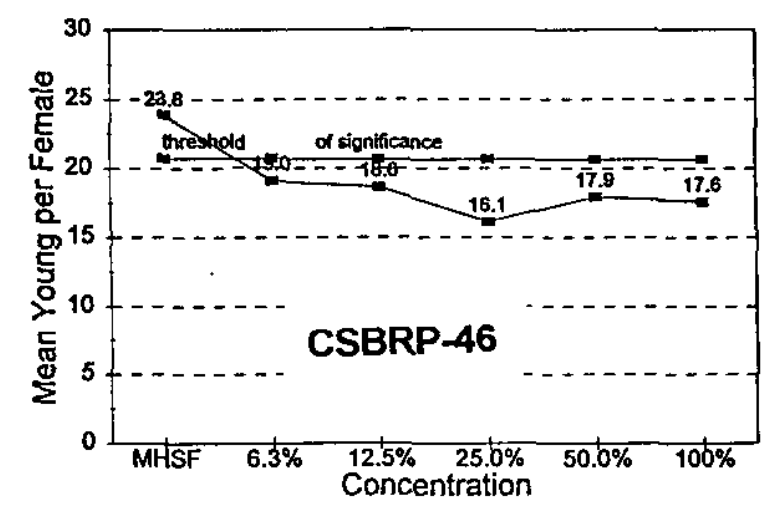

Effluent Conc. vs. Reproduction

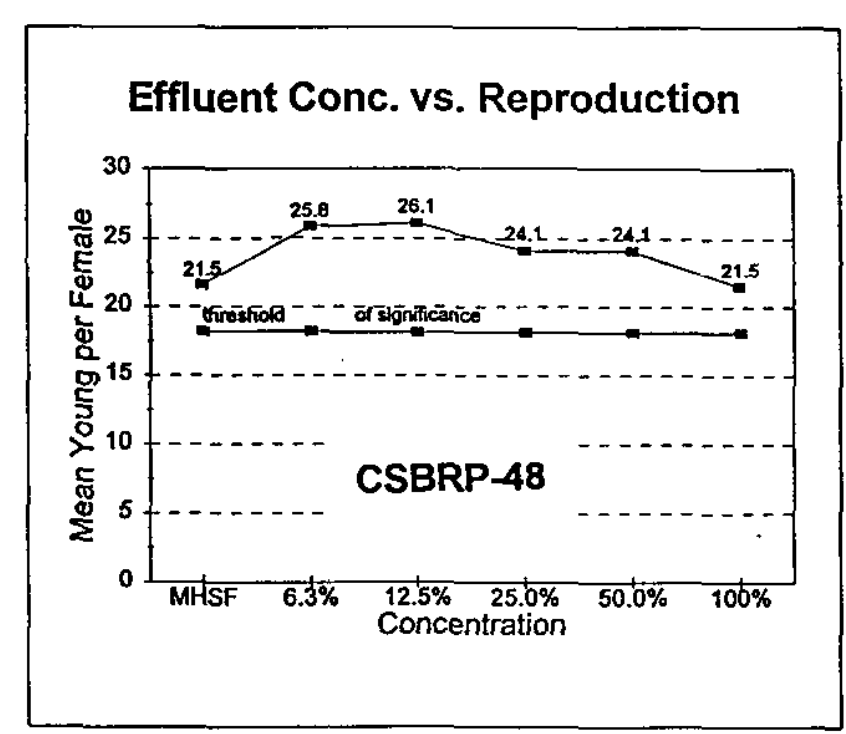

Effluent Conc. vs. Reproduction

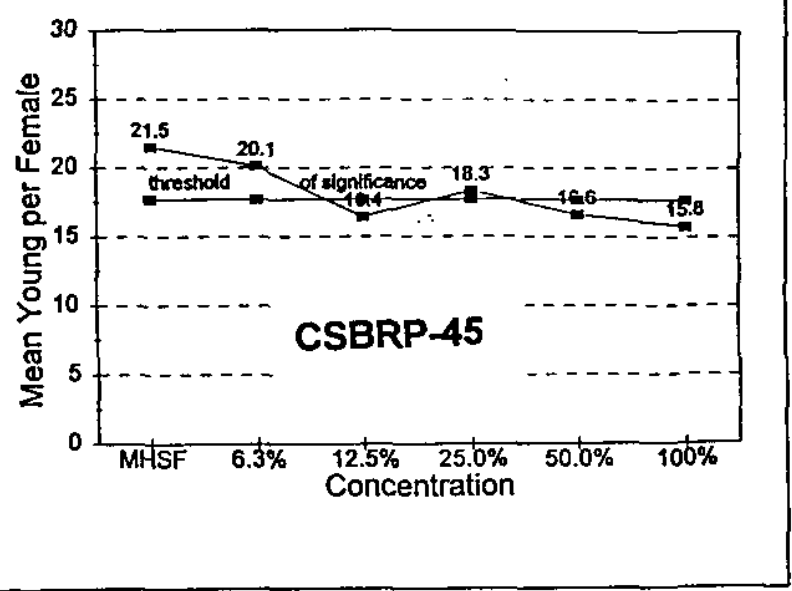

Effluent Conc. vs. Reproduction

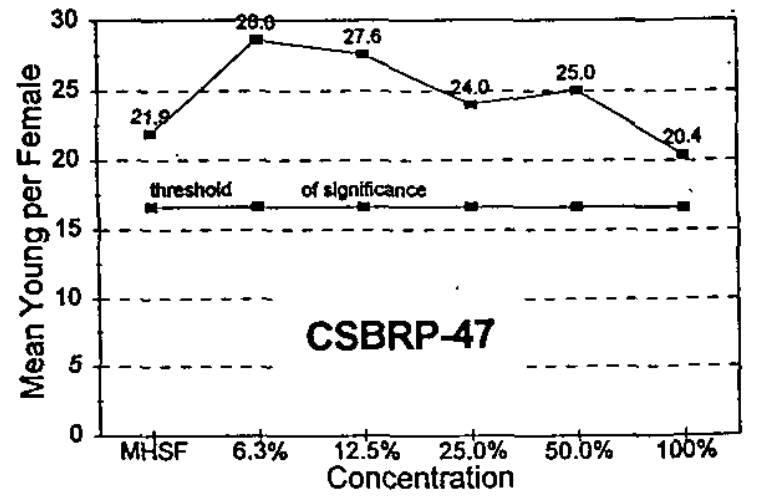

Figure 3. Results of Toxicity Tests on Water Samples Collected Near the CSBRP, January 1999 
(Table 11; Appendix 3). These results indicate that the sediments from the CSBRP should not result in significant mortality to indigenous organisms inhabiting these wetland areas.

Table 10. Results of Toxicity Tests Conducted on Sediment Samples from 4 Locations Near the Central Shops Burning Rubble Pit Waste Unit and an Unimpacted Reference Location, January, 1999

Location

Percent Survival Significant Mortality $(p=0.05)$

Control Sediment*

CSBRP-45-01-R

CSBRP-46-01-R

CSBRP-47-01-R

CSBRP-48-01-R

BKD-SED-1
$88.8 \%$

$\begin{array}{ll}68.8 \% & \text { Yes } \\ 81.4 \% & \text { No } \\ 76.3 \% & \text { Yes } \\ 67.5 \% & \text { Yes } \\ 75.0 \% & \text { Yes }\end{array}$

"The control sediment used for these tests was from Resurrection Creek, Greenville Co, SC.

Table 11 A Comparison of the Results of CSBRP Sediment Toxicity Tests to the Results from the Background Reference Sediment Toxicity Test

Location

BKD-SED-1

CSBRP-45-01-R

CSBRP-46-01-R

CSBRP-47-01-R

CSBRP-48-01-R

\section{Percent Survival}

$75.0 \%$

$68.8 \%$

$81.4 \%$

$76.3 \%$

$67.5 \%$
Significant Mortality $(p=0.05)$

\subsection{CONCLUSIONS}

Based on the results of the chemical analyses, unfiltered water samples collected from a wetland and settling basins located adjacent to the CSBRP Operable Unit exceed TRVs for aluminum, barium, chromium, copper, iron, lead, and vanadium at one or more of the four locations that were sampled. The water contained very high concentrations of clay particles that were present as suspended solids. A substantial portion of the metals was present as filterable particulates, bound to the clay particles, and was therefore not biologically available. Based on dissolved metal concentrations, the wetland and settling basin exceeded TRVs for aluminum, and barium. However, the background reference location also exceeded the TRV for barium, which suggests that this value may be too low, based on local geochemistry. Dissolved metal levels of chromium, copper, iron, lead and vanadium were below the TRVs. The detection limits for both total and dissolved mercury were higher than the TRV, so it was not possible to determine if the 
TRV for mercury was exceeded. Metal concentrations in the sediment exceeded the TRVs for arsenic, chromium, copper, and mercury, but did not exceed the TRVs for antimony and lead.

The results of the water toxicity tests indicated no evidence of acute toxicity in any of the samples. The results of the chronic toxicity tests indicated possible reproductive impairment at two locations. However, the results appear to be anomalous, since the toxicity was unrelated to concentration, and because the concentrations of PCOCs were similar in the toxic and the non-toxic samples. The results of the sediment toxicity tests indicated significant mortality in all but one sample, including the background reference sediment. However, when the results of the CSBRP sediment toxicity tests were statistically compared to the result from the background reference sediment collected at SRS, there were no significant differences in mortality. These results suggest that the surface water and sediment at the CSBRP Operable Unit is not toxic to the biota that inhabit the wetland and the settling basin.

\subsection{REFERENCES}

U.S. EPA. 1994. Methods for Measuring the Toxicity and Bioaccumulation of Sedimentassociated Contaminants with Freshwater Invertebrates. EPA600/R-94-024.

Weber, C.I., W.H. Peltier, T.J. Norberg-King, W.B. Horning II, F.A. Kessler, J.R. Menkedick, T.W. Neilheisel, P.A. Lewis, D.J. Klemm, Q.H. Pickering, E.L. Robinson, J.M. Lazorchak, L.J. Wymer, and R.W. Freyberg. 1989. Short-term Methods for Estimating the Chronic Toxicity of Effluents and Receiving Waters to Freshwater Organisms. EPA/600/4-89/001.

Westinghouse Savannah River Company. 1998. RFI/RI with BRA for the Central Shops Burning/Rubble Pits (631-1G and 631-3G) (U). WSRC-RP-98-4043, Rev. 0, Savannah River Site 


\section{APPENDIX 1}

Water Toxicity Test Reports 
P.O. Box 16414, Greenville, SC 29606 4 Craftsman Court, Greer, SC 29650

7 Day Chronic Definitive Survival and Reproduction Bioassay

Method: EPA/600/4-91/002

Test Organism: Ceriodaphnia dubia

Facility: WSRC

Sample ID: BKD SW-1

Aiken County

ETT\#: T11122

Sample ID: January 13, 1999

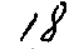




\section{CHRONIC DEFINITIVE SURVIVAL AND REPRODUCTION TEST Survival and Reproduction Results}

Client: WSRC

Sample Identification: $\quad$ BKD SW-1

Test Date: $\quad$ January 13, 1999

\begin{tabular}{|c|c|c|c|c|c|c|}
\hline \multicolumn{3}{|c|}{ Reproduction at } & \multirow{2}{*}{ MHSF } & \multicolumn{2}{|c|}{ Control } & \multirow[b]{2}{*}{ Total } \\
\hline Rep. & Day 3/4 & Day 5 & & Day 7 & Day 8 & \\
\hline 1 & 6 & 7 & 0 & 10 & 0 & 23 \\
\hline 2 & $\overline{0}$ & 0 & $\overline{8}$ & 12 & 0 & 20 \\
\hline 3 & 3 & 6 & 0 & 10 & 0 & 19 \\
\hline 4 & 4 & 0 & 8 & 11 & 0 & 23 \\
\hline 5 & 5 & 0 & 7 & 12 & 0 & 24 \\
\hline 6 & 0 & $\bar{x}$ & $\overline{\mathbf{X}}$ & $\bar{x}$ & $\bar{X}$ & 0 \\
\hline 7 & 6 & 7 & 0 & 12 & 0 & 25 \\
\hline 8 & 6 & 1 & 10 & 17 & 0 & 34 \\
\hline 9 & 4 & $\overline{0}$ & 11 & 14 & 0 & 29 \\
\hline 10 & 0 & 1 & 0 & 0 & 0 & 1 \\
\hline
\end{tabular}

\begin{tabular}{|c|c|c|c|c|c|c|}
\hline \multicolumn{2}{|c|}{ Reproduction at } & \multicolumn{2}{c|}{$12.5 \%$} & \multicolumn{2}{c|}{ Concentration } \\
\hline Rep. & Day 3/4 & Day 5 & Day 6 & Day 7 & Day 8 & Total \\
\hline 1 & 6 & 10 & 0 & 12 & 0 & 28 \\
\hline 2 & 5 & 0 & 9 & 14 & 0 & 28 \\
\hline 3 & 5 & 10 & 0 & 12 & 0 & 27 \\
\hline 4 & 3 & 0 & 9 & 12 & 0 & 24 \\
\hline 5 & 4 & 0 & 10 & 11 & 0 & 25 \\
\hline 6 & 4 & 7 & 0 & 10 & 0 & 21 \\
\hline 7 & 4 & 9 & 0 & 15 & 0 & 28 \\
\hline 8 & 4 & 0 & 12 & 15 & 0 & 31 \\
\hline 9 & 5 & 7 & 0 & 14 & 0 & 26 \\
\hline 10 & 5 & 8 & 0 & 14 & 0 & 27 \\
\hline
\end{tabular}

\begin{tabular}{|c|c|c|c|c|c|c|}
\hline \multicolumn{2}{|c|}{ Reproduction at } & \multicolumn{3}{c|}{$50 \%$} & \multicolumn{3}{c|}{ Concentration } \\
\hline Rep. & Day 3/4 & Day 5 & Day 6 & Day 7 & Day 8 & Total \\
\hline 1 & 7 & 10 & 0 & 12 & 0 & 29 \\
\hline 2 & 4 & 5 & 0 & 15 & 0 & 24 \\
\hline 3 & 4 & 5 & 0 & 14 & 0 & 23 \\
\hline 4 & 3 & 6 & 0 & 20 & 0 & 29 \\
\hline 5 & 2 & 0 & 8 & 14 & 0 & 24 \\
\hline 6 & 4 & 0 & 7 & 12 & 0 & 23 \\
\hline 7 & 5 & 6 & 0 & 12 & 0 & 23 \\
\hline 8 & 4 & 7 & 0 & 10 & 0 & 21 \\
\hline 9 & 3 & 6 & 0 & 14 & 0 & 23 \\
\hline 10 & 0 & 3 & 0 & 10 & 0 & 13 \\
\hline
\end{tabular}

County:

NPDES\#:

ETT \#:

Aiken

T11122

\begin{tabular}{|c|c|c|c|c|c|c|}
\hline \multicolumn{2}{|c|}{ Reproduction at } & \multicolumn{2}{c|}{$6.25 \%$} & \multicolumn{2}{c|}{ Concentration } \\
\hline Rep. & Day 3/4 & Day 5 & Day 6 & Day 7 & Day 8 & Total \\
\hline 1 & 2 & 11 & 0 & 15 & 0 & 28 \\
\hline 2 & 4 & 0 & 9 & 12 & 0 & 25 \\
\hline 3 & 5 & 7 & 0 & 14 & 0 & 26 \\
\hline 4 & 3 & 0 & 8 & 14 & 0 & 25 \\
\hline 5 & 4 & 0 & 9 & 12 & 0 & 25 \\
\hline 6 & 3 & 0 & 10 & 14 & 0 & 27 \\
\hline 7 & 5 & 5 & 0 & 14 & 0 & 24 \\
\hline 8 & 3 & 0 & 6 & 8 & 0 & 17 \\
\hline 9 & 4 & 0 & 5 & 11 & 0 & 20 \\
\hline 10 & 6 & 6 & 0 & 9 & 0 & 21 \\
\hline
\end{tabular}

\begin{tabular}{|c|c|c|c|c|c|c|}
\hline \multicolumn{2}{|c|}{ Reproduction at } & \multicolumn{2}{c|}{$25 \%$} & \multicolumn{2}{c|}{ Concentration } \\
\hline Rep. & Day 3/4 & Day 5 & Day 6 & Day 7 & Day 8 & Total \\
\hline 1 & 5 & 12 & 0 & 14 & 0 & 31 \\
\hline 2 & 0 & 6 & 0 & 12 & 0 & 18 \\
\hline 3 & 3 & 5 & 0 & 8 & 0 & 16 \\
\hline 4 & 4 & 8 & 0 & 12 & 0 & 24 \\
\hline 5 & 4 & 0 & 10 & 15 & 0 & 29 \\
\hline 6 & 5 & 0 & 8 & 14 & 0 & 27 \\
\hline 7 & 6 & 7 & 0 & 15 & 0 & 28 \\
\hline 8 & 4 & 0 & 8 & 14 & 0 & 26 \\
\hline 9 & 3 & 6 & 0 & 12 & 0 & 21 \\
\hline 10 & 5 & 4 & 0 & 12 & 0 & 21 \\
\hline
\end{tabular}

\begin{tabular}{|c|c|c|c|c|c|c|}
\hline \multicolumn{2}{|c|}{ Reproduction at } & \multicolumn{4}{c|}{$100 \%$} & \multicolumn{3}{c|}{ Concentration } \\
\hline Rep. & Day 3/4 & Day 5 & Day 6 & Day 7 & Day 8 & Total \\
\hline 1 & 2 & 8 & 0 & 9 & 0 & 19 \\
\hline 2 & 4 & 0 & 2 & 5 & 0 & 11 \\
\hline 3 & 0 & 0 & 0 & 0 & 0 & 0 \\
\hline 4 & 3 & 0 & 0 & 0 & 0 & 3 \\
\hline 5 & 2 & $X$ & $X$ & $X$ & $X$ & 2 \\
\hline 6 & 3 & 0 & 0 & 10 & 0 & 13 \\
\hline 7 & 2 & 4 & 0 & 8 & 0 & 14 \\
\hline 8 & 3 & 0 & 6 & 10 & 0 & 19 \\
\hline 9 & 2 & 0 & 0 & 5 & 0 & 7 \\
\hline 10 & 3 & 0 & 0 & 0 & 0 & 3 \\
\hline
\end{tabular}




\section{CHRONIC DEFINITIVE SURVIVAL AND REPRODUCTION TEST \\ Statistical Analyses}

Client: $\quad$ WSRC

Sample Identification: BKD SW-1

Test Date: January 13, 1999

\section{Test for Normality}

Test Used: Kolmogorov D

$\begin{array}{ll}\mathrm{D}= & 0.991 \\ \text { critical } & 1.035\end{array}$

The data are normal in distribution

\section{Test for Differences in Reproduction}

\section{Test Type Used: \\ Fishers Exact Test for Survival}

Test Type Used:

Wilcoxon's Test for Reproduction

\begin{tabular}{|c|c|c|c|c|c|c|}
\hline \multirow[t]{2}{*}{$t$ Test } & \multicolumn{6}{|c|}{ Test Concentration } \\
\hline & MHSF & $6.3 \%$ & $12.5 \%$ & $25.0 \%$ & $50.0 \%$ & $100 \%$ \\
\hline It Value & & -0.74 & -1.77 & -0.85 & -0.50 & 4.92 \\
\hline eritical t & & 2.28 & 2.28 & 2.28 & 2.28 & 2.28 \\
\hline reproduct. & 21.9 & 23.8 & 26.5 & 24.1 & 23.2 & 9.1 \\
\hline survival & $89 \%$ & $100 \%$ & $100 \%$ & $100 \%$ & $100 \%$ & $90 \%$ \\
\hline $\mathrm{CV}=$ & $43 \%$ & & & & $\mathrm{MSD}=$ & 6.05 \\
\hline
\end{tabular}

Wilcoxon's Test

Wilcoxon's Test
\begin{tabular}{|l|r|r|r|r|r|} 
& $6.3 \%$ & $12.5 \%$ & $25.0 \%$ & $50 \%$ & $100 \%$ \\
\hline rank sum & & & & & \\
\hline critical value & 75 & 75 & 75 & 75 & 75 \\
\hline
\end{tabular}

critical value

\section{Reproduction:}

NOEC: Survival: $\quad>100 \%$

LOEC: Survival: $>100 \%$

Chronic Value:
Reproduction:

$70.7 \%$
$50.0 \%$

$100.0 \%$

\section{Test for Homogeneity of Variance}

Test Used: Bartlett's Test

$\begin{array}{rr}\mathrm{B}= & 20.64 \\ \text { critical } & 15.1\end{array}$

The data are not homogeneous in variance

\section{Effluent Conc. vs. Reproduction}

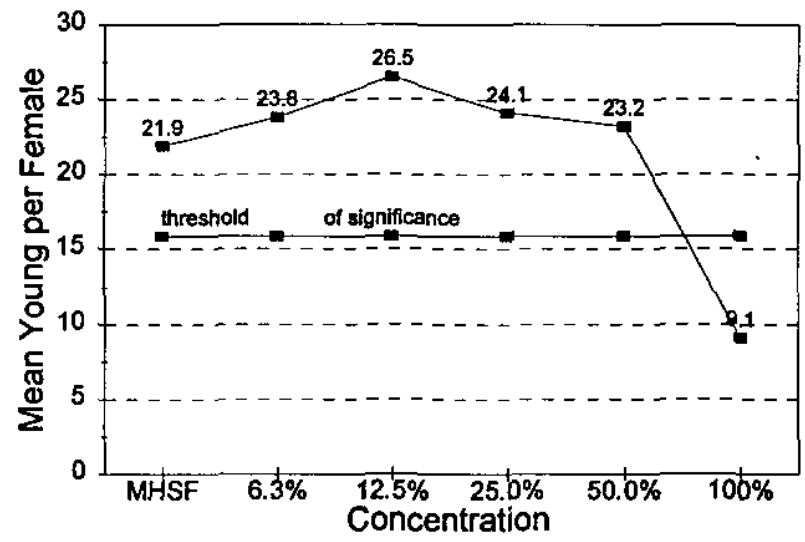

Summary

The effluent is not acutely toxic.

The effluent is chronically toxic at $100 \%$ concentration. 


\section{CHRONIC DEFINITIVE SURVIVAL AND REPRODUCTION TEST Water Chemistry}

Client: $\quad$ WSRC

Sample Identification: $\quad$ BKD SW-1

Test Date: $\quad$ January 13, 1999

pH (After Renewal)

\begin{tabular}{|l|r|r|r|r|r|r|}
\hline \multicolumn{7}{|c|}{ Test Concentration } \\
\hline & Control & $6.25 \%$ & $12.5 \%$ & $25 \%$ & $50 \%$ & $100 \%$ \\
\hline Initial & 7.70 & 7.93 & 7.46 & 7.83 & 6.86 & 5.53 \\
\hline Day 1 & 7.70 & 6.95 & 6.96 & 6.91 & 6.79 & 6.28 \\
\hline Day 2 & 7.79 & 7.95 & 7.98 & 7.99 & 7.89 & 7.74 \\
\hline Day 3 & 7.72 & 7.59 & 7.62 & 7.63 & 7.90 & 6.17 \\
\hline Day 4 & 7.59 & 7.71 & 7.93 & 7.68 & 7.59 & 7.90 \\
\hline Day 5 & 7.75 & 7.61 & 7.56 & 7.54 & 7.41 & 5.82 \\
\hline Day 6 & 7.63 & 8.02 & 7.97 & 8.04 & 7.66 & 7.69 \\
\hline
\end{tabular}

Dissolved Oxygen (After Renewal)

\begin{tabular}{|l|r|r|r|r|r|r|}
\hline \multicolumn{7}{|c|}{ Test Concentration } \\
\hline & Control & $6.25 \%$ & $12.5 \%$ & $25 \%$ & $50 \%$ & $100 \%$ \\
\hline Initial & 8.4 & 8.4 & 8.4 & 8.3 & 8.2 & 7.8 \\
\hline Day 1 & 8.3 & 8.2 & 8.4 & 8.4 & 8.4 & 8.3 \\
\hline Day 2 & 8.5 & 8.4 & 8.5 & 8.6 & 8.6 & 8.5 \\
\hline Day 3 & 8.3 & 8.8 & 8.9 & 9.0 & 9.0 & 9.0 \\
\hline Day 4 & 8.3 & 8.8 & 8.8 & 8.9 & 9.2 & 9.1 \\
\hline Day 5 & 8.3 & 8.9 & 9.1 & 9.1 & 9.0 & 9.1 \\
\hline Day 6 & 8.5 & 8.4 & 8.4 & 8.5 & 8.6 & 8.6 \\
\hline
\end{tabular}

\section{pH (Before Renewal)}

\begin{tabular}{|l|r|r|r|r|r|r|}
\hline \multicolumn{7}{|c|}{ Test Concentration } \\
\hline & Control & $6.25 \%$ & $12.5 \%$ & $25 \%$ & $50 \%$ & $100 \%$ \\
\hline Day 1 & 8.10 & 7.90 & 7.94 & 7.93 & 7.93 & 7.87 \\
\hline Day 2 & 8.15 & 7.99 & 8.03 & 8.01 & 7.97 & 8.14 \\
\hline Day 3 & 8.09 & 7.93 & 7.98 & 7.93 & 8.01 & 6.95 \\
\hline Day 4 & 7.97 & 7.97 & 7.82 & 8.01 & 7.79 & 6.93 \\
\hline Day 5 & 8.12 & 8.04 & 7.97 & & 8.07 & 6.37 \\
\hline Day 6 & 8.02 & 7.83 & 8.09 & 7.97 & 7.96 & 6.88 \\
\hline Final & 7.94 & 8.02 & 8.04 & 8.02 & 7.87 & 7.18 \\
\hline
\end{tabular}

\section{Dissolved Oxygen (Before Renewal)}

\begin{tabular}{|l|r|r|r|r|r|r|}
\hline \multicolumn{7}{|c|}{ Test Concentration } \\
\hline & Control & $6.25 \%$ & $12.5 \%$ & $25 \%$ & $50 \%$ & $100 \%$ \\
\hline Day 1 & 8.4 & 8.4 & 8.3 & 8.4 & 8.4 & 8.4 \\
\hline Day 2 & 8.6 & 8.3 & 8.4 & 8.6 & 8.7 & 8.7 \\
\hline Day 3 & 8.6 & 8.6 & 8.8 & 8.9 & 8.9 & 8.9 \\
\hline Day 4 & 8.3 & 8.9 & 8.8 & 8.8 & 8.9 & 8.8 \\
\hline Day 5 & 8.8 & 8.3 & 8.4 & & 8.6 & 8.7 \\
\hline Day 6 & 8.7 & 8.5 & 8.4 & 8.5 & 8.7 & 8.6 \\
\hline Final & 8.5 & 8.2 & 8.2 & 8.6 & 8.3 & 8.0 \\
\hline
\end{tabular}

\begin{tabular}{|c|c|c|c|c|}
\hline Date & Alkalinity & Hardness & Conductivity & Res. Cl. \\
\hline $1-11-99$ & 4.26 & 8.16 & 26.4 & 0.03 \\
\hline $1-13-99$ & 4.16 & 22.4 & 26 & 0.03 \\
\hline $1-15-99$ & 8.32 & 12.2 & 26.5 & $<0.01$ \\
\hline
\end{tabular}

\section{Temperature}

\begin{tabular}{|l|r|}
\hline \multicolumn{2}{|c|}{ Incubator ${ }^{\circ} \mathrm{C}$} \\
\hline Initial & 24.9 \\
\hline Day 1 & 25.0 \\
\hline Day 2 & 24.7 \\
\hline Day 3 & 25.0 \\
\hline Day 4 & 25.1 \\
\hline Day 5 & 25.0 \\
\hline Day 6 & 25.1 \\
\hline Final & 24.5 \\
\hline
\end{tabular}




\section{Day Chronic Definitive Survival} and Reproduction Bioassay

Method: EPA/600/4-91/002

Test Organism:

Ceriodaphnia dubia

Facility: WSRC

Sample ID:CSBRP-45-02-R

Aiken County

ETT\#: T11121

Sample ID: January 13, 1999 


\section{CHRONIC DEFINITIVE SURVIVAL AND REPRODUCTION TEST Survival and Reproduction Results}

Client: WSRC

Sample Identification: CSBRP-45-02-R

Test Date: $\quad$ January 13, 1999

\begin{tabular}{|c|c|c|c|c|c|c|}
\hline \multicolumn{7}{|c|}{ Reproduction at } \\
\hline Rep. & Day 3/4 & Day 5 & Day 6 & Day 7 & Day 8 & Total \\
\hline 1 & 5 & 7 & 0 & 12 & 0 & 24 \\
\hline 2 & 5 & 8 & 0 & 11 & 0 & 24 \\
\hline 3 & 7 & 10 & 0 & 10 & 0 & 27 \\
\hline 4 & 0 & 0 & 8 & 11 & 0 & 19 \\
\hline 5 & 0 & 0 & 3 & 13 & 0 & 16 \\
\hline 6 & 4 & 10 & 0 & 13 & 0 & 27 \\
\hline 7 & 5 & 0 & 6 & 11 & 0 & 22 \\
\hline 8 & 0 & 4 & 0 & 15 & 0 & 19 \\
\hline 9 & 3 & 9 & 0 & 9 & 0 & 21 \\
\hline 10 & 0 & 6 & 0 & 10 & 0 & 16 \\
\hline
\end{tabular}

\begin{tabular}{|c|c|c|c|c|c|c|}
\hline \multicolumn{2}{|c|}{ Reproduction at } & \multicolumn{2}{c|}{$12.5 \%$} & \multicolumn{3}{c|}{ Concentration } \\
\hline Rep. & Day 3/4 & Day 5 & Day 6 & Day 7 & Day 8 & Total \\
\hline 1 & 5 & 9 & 0 & 7 & 4 & 25 \\
\hline 2 & 5 & 7 & 0 & 5 & 1 & 18 \\
\hline 3 & 7 & 10 & 0 & 2 & 0 & 19 \\
\hline 4 & 5 & 0 & 5 & 6 & 0 & 16 \\
\hline 5 & 2 & 0 & 7 & 4 & 0 & 13 \\
\hline 6 & 0 & 0 & 7 & 4 & 2 & 13 \\
\hline 7 & 4 & 0 & 4 & 6 & 0 & 14 \\
\hline 8 & 4 & 8 & 2 & 2 & 0 & 16 \\
\hline 9 & 4 & 5 & 2 & 3 & 1 & 15 \\
\hline 10 & 4 & 8 & 0 & 3 & 0 & 15 \\
\hline
\end{tabular}

\begin{tabular}{|c|c|c|c|c|c|c|}
\hline \multicolumn{2}{|c|}{ Reproduction at } & \multicolumn{2}{c|}{$50 \%$} & \multicolumn{3}{c|}{ Concentration } \\
\hline Rep. & Day 3/4 & Day 5 & Day 6 & Day 7 & Day 8 & Total \\
\hline 1 & 4 & 12 & 0 & 1 & 0 & 17 \\
\hline 2 & 5 & 12 & 0 & 3 & 2 & 22 \\
\hline 3 & 6 & 9 & 1 & 3 & 0 & 19 \\
\hline 4 & 5 & 0 & 6 & 1 & 1 & 13 \\
\hline 5 & 6 & 4 & 0 & 2 & 0 & 12 \\
\hline 6 & 6 & 0 & 8 & 0 & 0 & 14 \\
\hline 7 & 5 & 0 & 9 & 1 & 2 & 17 \\
\hline 8 & 5 & 6 & 0 & 1 & 0 & 12 \\
\hline 9 & 5 & 0 & 10 & 3 & 2 & 20 \\
\hline 10 & 5 & 10 & 0 & 4 & 1 & 20 \\
\hline
\end{tabular}

County:

NPDES\#:

ETT \#:

Aiken

T11121

\begin{tabular}{|c|c|c|c|c|c|c|}
\hline Reproduction at & \multicolumn{4}{c|}{$6.25 \%$} & \multicolumn{2}{c|}{ Concentration } \\
\hline Rep. & Day 3/4 & Day 5 & Day 6 & Day 7 & Day 8 & Total \\
\hline 1 & 5 & 8 & 0 & 6 & 4 & 23 \\
\hline 2 & 6 & 10 & 0 & 2 & 8 & 26 \\
\hline 3 & 6 & 8 & 0 & 5 & 10 & 29 \\
\hline 4 & 5 & 0 & 7 & 3 & 2 & 17 \\
\hline 5 & 3 & 0 & 6 & 6 & 4 & 19 \\
\hline 6 & 1 & 0 & 11 & 5 & 1 & 18 \\
\hline 7 & 4 & 0 & 7 & 4 & 0 & 15 \\
\hline 8 & 4 & 9 & 0 & 5 & 0 & 18 \\
\hline 9 & 3 & 4 & 4 & 3 & 2 & 16 \\
\hline 10 & 3 & 6 & 0 & L & L & L \\
\hline
\end{tabular}

\begin{tabular}{|c|c|c|c|c|c|c|}
\hline \multicolumn{2}{|c|}{ Reproduction at } & \multicolumn{2}{c|}{$25 \%$} & \multicolumn{3}{c|}{ Concentration } \\
\hline Rep. & Day 3/4 & Day 5 & Day 6 & Day 7 & Day 8 & Total \\
\hline 1 & 4 & 8 & 0 & 5 & 0 & 17 \\
\hline 2 & 4 & 10 & 0 & 5 & 0 & 19 \\
\hline 3 & 6 & 9 & 0 & 3 & 0 & 18 \\
\hline 4 & 5 & 0 & 7 & 5 & 1 & 18 \\
\hline 5 & 5 & 0 & 7 & 5 & 1 & 18 \\
\hline 6 & 5 & 0 & 9 & 3 & 0 & 17 \\
\hline 7 & 5 & 0 & 9 & 0 & 2 & 16 \\
\hline 8 & 4 & 8 & 0 & 2 & 1 & 15 \\
\hline 9 & 5 & 9 & 0 & 4 & 0 & 18 \\
\hline 10 & 5 & 11 & 0 & 4 & 7 & 27 \\
\hline
\end{tabular}

\begin{tabular}{|c|c|c|c|c|c|c|}
\hline \multicolumn{2}{|c|}{ Reproduction at } & \multicolumn{4}{c|}{$100 \%$} & \multicolumn{3}{c|}{ Concentration } \\
\hline Rep. & Day 3/4 & Day 5 & Day 6 & Day 7 & Day 8 & Total \\
\hline 1 & 3 & 7 & 0 & 1 & 1 & 12 \\
\hline 2 & 4 & 8 & 0 & 3 & 4 & 19 \\
\hline 3 & 3 & 7 & 0 & 2 & 3 & 15 \\
\hline 4 & 4 & 0 & 7 & 1 & 1 & 13 \\
\hline 5 & 3 & 0 & 6 & 3 & 5 & 17 \\
\hline 6 & 4 & 0 & 7 & 2 & 4 & 17 \\
\hline 7 & 3 & 6 & 0 & 2 & 4 & 15 \\
\hline 8 & 4 & 6 & 0 & 4 & 5 & 19 \\
\hline 9 & 2 & 5 & 0 & 3 & 4 & 14 \\
\hline 10 & 4 & 7 & 0 & 3 & 3 & 17 \\
\hline
\end{tabular}




\section{CHRONIC DEFINITIVE SURVIVAL AND REPRODUCTION TEST \\ Statistical Analyses}

Client: $\quad$ WSRC

Sample Identification: CSBRP-45-02-R

Test Date: $\quad$ January 13, 1999

\begin{tabular}{|clc|}
\hline Test for Normality & & \\
& & \\
Test Used: Kolmogorov D & critical & 0.990 \\
& 1.035 \\
The data are normal in distribution & \\
\end{tabular}

\begin{tabular}{|c|c|c|}
\hline \multicolumn{3}{|c|}{ Test for Homogeneity of Variance } \\
\hline Test Used: Bartlett's Test & $\underset{\text { critical }}{B=}$ & $\begin{array}{l}4.99 \\
15.1\end{array}$ \\
\hline
\end{tabular}

\begin{tabular}{|c|c|c|c|c|c|c|}
\hline \multicolumn{7}{|c|}{ Test for Differences in Reproduction } \\
\hline \multicolumn{2}{|c|}{$\begin{array}{l}\text { Test Type Used: } \\
\text { Test Type Used: }\end{array}$} & \multicolumn{5}{|c|}{ Fishers Eract Test for Survival } \\
\hline \multirow[t]{2}{*}{ t Test } & \multicolumn{6}{|c|}{ Test Concentration } \\
\hline & MHSF & $6.3 \%$ & $12.5 \%$ & $25.0 \%$ & $50.0 \%$ & $100 \%$ \\
\hline \multicolumn{2}{|l|}{ t Value } & 0.83 & 3.13 & 1.97 & 3.01 & 3.50 \\
\hline \multicolumn{2}{|l|}{ crítical t } & 2.28 & 2.28 & 2.28 & 2.28 & 2.28 \\
\hline reproduct. & 21.5 & 20.1 & 16.4 & 18.3 & 16.6 & 15.8 \\
\hline survival & $100 \%$ & $100 \%$ & $100 \%$ & $100 \%$ & $100 \%$ & $100 \%$ \\
\hline \multirow{3}{*}{\multicolumn{2}{|c|}{$\mathrm{CV}=$}} & & & & $\mathrm{MSD}=$ & 3.79 \\
\hline & & \multicolumn{5}{|c|}{ Test Concentration } \\
\hline & & $6.3 \%$ & $12.5 \%$ & $25.0 \%$ & $50 \%$ & $100 \%$ \\
\hline \multicolumn{7}{|l|}{ rank sum } \\
\hline \multicolumn{2}{|c|}{ critical value } & 75 & 75 & 75 & 75 & 75 \\
\hline \multirow{2}{*}{\multicolumn{3}{|c|}{ 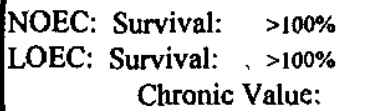 }} & \multirow{2}{*}{\multicolumn{2}{|c|}{$\begin{array}{c}\text { Reproduction: } \\
\text { Reproduction: } \\
8.8 \%\end{array}$}} & $6.3 \%$ & \\
\hline & & & & & $12.5 \%$ & \\
\hline
\end{tabular}

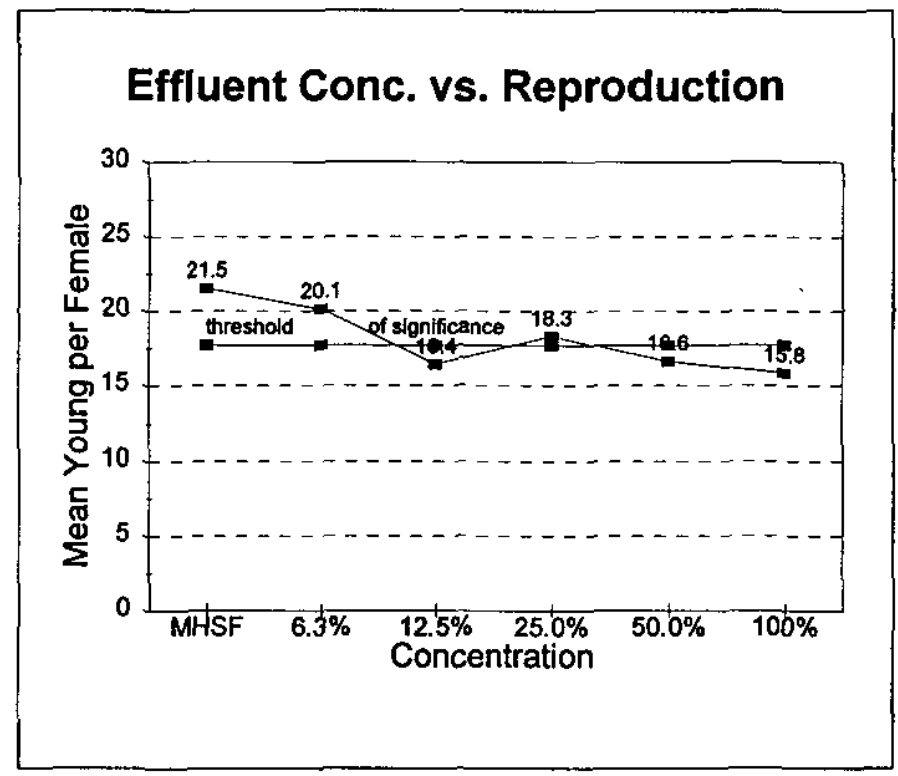

\section{Summary}

The effluent is not acutely toxic.

The effluent is chronically toxic at concentrations of $12.5 \%$ and higher. However, the suppression of reproduction is small and may be a statistical anomaly. 


\section{CHRONIC DEFINITIVE SURVIVAL AND REPRODUCTION TEST \\ Water Chemistry}

Client: WSRC

Sample Identification: CSBRP-45-02-R

Test Date: $\quad$ January 13, 1999

\section{pH (After Renewal)}

\begin{tabular}{|l|r|r|r|r|r|r|}
\hline \multicolumn{7}{|c|}{ Test Concentration } \\
\hline & Contro! & $6.25 \%$ & $12.5 \%$ & $25 \%$ & $50 \%$ & $100 \%$ \\
\hline Initial & 7.70 & 7.85 & 7.53 & 7.46 & 7.70 & 7.12 \\
\hline Day 1 & 7.70 & 6.72 & 6.89 & 6.92 & 6.94 & 6.92 \\
\hline Day 2 & 7.79 & 8.18 & 8.13 & 8.24 & 8.23 & 8.20 \\
\hline Day 3 & 7.72 & 7.71 & 7.73 & 7.75 & 7.76 & 7.67 \\
\hline Day 4 & 7.59 & 7.60 & 7.64 & 7.57 & 7.63 & 7.59 \\
\hline Day 5 & 7.75 & 7.82 & 7.84 & 7.72 & 7.68 & 7.54 \\
\hline Day 6 & 7.63 & 7.88 & 7.60 & 7.93 & 7.94 & 7.98 \\
\hline
\end{tabular}

Dissolved Oxygen (After Renewal)

\begin{tabular}{|l|r|r|r|r|r|r|}
\hline \multicolumn{7}{|c|}{ Test Concentration } \\
\hline & Control & $6.25 \%$ & $12.5 \%$ & $25 \%$ & $50 \%$ & $100 \%$ \\
\hline Initial & 8.4 & 8.7 & 8.7 & 8.8 & 8.9 & 9.4 \\
\hline Day 1 & 8.3 & 8.6 & 8.6 & 8.5 & 8.6 & 8.6 \\
\hline Day 2 & 8.5 & 8.6 & 8.6 & 8.7 & 8.7 & 8.8 \\
\hline Day 3 & 8.3 & 8.7 & 8.8 & 8.8 & 8.8 & 9.0 \\
\hline Day 4 & 8.3 & 9.1 & 9.0 & 9.1 & 9.4 & 9.4 \\
\hline Day 5 & 8.3 & 8.9 & 8.9 & 8.9 & 9.0 & 9.1 \\
\hline Day 6 & 8.5 & 8.3 & 8.4 & 8.4 & 8.5 & 8.5 \\
\hline
\end{tabular}

pH (Before Renewal)

\begin{tabular}{|l|r|r|r|r|r|r|}
\hline \multicolumn{7}{|c|}{ Test Concentration } \\
\hline & Control & $6.25 \%$ & $12.5 \%$ & $25 \%$ & $50 \%$ & $100 \%$ \\
\hline Day 1 & 8.10 & 7.88 & 7.91 & 7.93 & 8.06 & 8.16 \\
\hline Day 2 & 8.15 & 8.23 & 8.23 & 8.34 & 8.27 & 8.44 \\
\hline Day 3 & 8.09 & 8.08 & 7.91 & 8.10 & 7.68 & 8.33 \\
\hline Day 4 & 7.97 & 8.10 & 8.11 & 8.31 & 7.82 & 8.47 \\
\hline Day 5 & 8.12 & 8.01 & 8.01 & 8.08 & 8.09 & 8.06 \\
\hline Day 6 & 8.02 & 8.21 & 8.16 & 7.80 & 8.17 & 8.14 \\
\hline Final & 7.94 & 8.14 & 8.37 & 8.41 & 8.20 & 8.31 \\
\hline
\end{tabular}

Dissolved Oxygen (Before Renewal)

\begin{tabular}{|l|r|r|r|r|r|r|}
\hline & \multicolumn{7}{|c|}{ Test Concentration } \\
\hline & Control & $6.25 \%$ & $12.5 \%$ & $25 \%$ & $50 \%$ & $100 \%$ \\
\hline Day 1 & 8.4 & 8.6 & 8.6 & 8.7 & 8.7 & 8.7 \\
\hline Day 2 & 8.6 & 8.8 & 8.7 & 8.8 & 8.8 & 8.8 \\
\hline Day 3 & 8.6 & 8.5 & 8.6 & 8.7 & 8.8 & 8.9 \\
\hline Day 4 & 8.3 & 8.4 & 8.4 & 8.5 & 8.5 & 8.6 \\
\hline Day 5 & 8.8 & 8.5 & 8.6 & 8.6 & 8.8 & 8.8 \\
\hline Day 6 & 8.7 & 8.5 & 8.5 & 8.5 & 8.6 & 8.6 \\
\hline Final & 8.5 & 8.4 & 8.6 & 8.7 & 8.7 & 8.7 \\
\hline
\end{tabular}

\begin{tabular}{|c|c|c|c|c|}
\hline Date & Alkalinity & Hardness & Conductivity & Res. Cl. \\
\hline $1-11-99$ & 183.2 & 175.4 & 385 & 0.08 \\
\hline $1-13-99$ & 199.7 & 185.6 & 421 & 0.1 \\
\hline $1-15-99$ & 79 & 93.8 & 182 & $<0.01$ \\
\hline
\end{tabular}

Temperature
\begin{tabular}{|l|r|}
\hline \multicolumn{2}{|c|}{ Incubator ${ }^{\circ} \mathrm{C}$} \\
\hline Initial & 24.9 \\
\hline Day 1 & 25.0 \\
\hline Day 2 & 24.7 \\
\hline Day 3 & 25.0 \\
\hline Day 4 & 25.1 \\
\hline Day 5 & 25.0 \\
\hline Day 6 & 25.1 \\
\hline Final & 24.5 \\
\hline
\end{tabular}

Test Results Reviewed and Approved By:

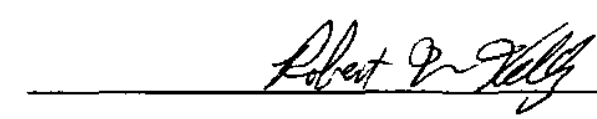




\section{Day Chronic Definitive Survival and Reproduction Bioassay \\ Method: EPA/600/4-91/002}

Test Organism: $\quad$ Ceriodaphnia dubia

Facility: WSRC

Sample ID:CSBRP-46-02-R

Aiken County

ETT\#: T11118

Sample ID: January 13, 1999 


\section{CHRONIC DEFINITIVE SURVIVAL AND REPRODUCTION TEST Survival and Reproduction Results}

Client:

Sample Identification:

Test Date:

WSRC

January 13, 1999

\begin{tabular}{|c|c|c|c|c|c|c|}
\hline \multicolumn{2}{|c|}{ Reproduction at } & MHSF & Control \\
\hline Rep. & Day 3/4 & Day 5 & Day 6 & Day 7 & Day 8 & Total \\
\hline 1 & 6 & 7 & 0 & 10 & 0 & 23 \\
\hline 2 & 0 & 0 & 8 & 12 & 0 & 20 \\
\hline 3 & 3 & 6 & 0 & 10 & 0 & 19 \\
\hline 4 & 4 & 0 & 8 & 11 & 0 & 23 \\
\hline 5 & 5 & 0 & 7 & 12 & 0 & 24 \\
\hline 6 & 0 & $X$ & $X$ & $X$ & $X$ & 0 \\
\hline 7 & 6 & 7 & 0 & 12 & 0 & 25 \\
\hline 8 & 6 & 1 & 10 & 17 & 0 & 34 \\
\hline 9 & 4 & 0 & 11 & 14 & 0 & 29 \\
\hline 10 & 0 & 1 & 0 & 0 & 0 & 1 \\
\hline
\end{tabular}

\begin{tabular}{|c|c|c|c|c|c|c|}
\hline \multicolumn{2}{|c|}{ Reproduction at } & \multicolumn{2}{c|}{$12.5 \%$} & \multicolumn{2}{c|}{ Concentration } \\
\hline Rep. & Day 3/4 & Day 5 & Day 6 & Day 7 & Day 8 & Total \\
\hline 1 & 0 & 4 & 7 & 0 & 8 & 19 \\
\hline 2 & 0 & 5 & 0 & 4 & 8 & 17 \\
\hline 3 & 0 & 6 & 0 & 6 & 10 & 22 \\
\hline 4 & 4 & 0 & 8 & 7 & 3 & 22 \\
\hline 5 & 0 & 5 & 0 & 3 & 11 & 19 \\
\hline 6 & 0 & 6 & 0 & 4 & 6 & 16 \\
\hline 7 & 3 & 0 & 8 & 9 & 2 & 22 \\
\hline 8 & 3 & 0 & 6 & 8 & 0 & 17 \\
\hline 9 & 2 & 0 & 5 & 5 & 3 & 15 \\
\hline 10 & 1 & 1 & 8 & 6 & 1 & 17 \\
\hline
\end{tabular}

\begin{tabular}{|} 
Reproduction at \\
\hline Rep. & Day 3/4 & Day 5 & Day 6 & Day 7 & Day 8 & Total \\
\hline 1 & 0 & 0 & 6 & 7 & 9 & 22 \\
\hline 2 & 0 & 4 & 7 & 0 & 8 & 19 \\
\hline 3 & 0 & 0 & 4 & 5 & 7 & 16 \\
\hline 4 & 0 & 0 & 5 & 4 & 7 & 16 \\
\hline 5 & 0 & 1 & 6 & 3 & 5 & 15 \\
\hline 6 & 0 & 0 & 4 & 4 & 5 & 13 \\
\hline 7 & 0 & 1 & 6 & 6 & 7 & 20 \\
\hline 8 & 0 & 0 & 6 & 5 & 8 & 19 \\
\hline 9 & 2 & 0 & 8 & 8 & 8 & 26 \\
\hline 10 & 0 & 0 & 6 & 3 & 4 & 13 \\
\hline
\end{tabular}

$\begin{array}{ll}\text { County: } & \text { Aiken } \\ \text { NPDES\#: } & \\ \text { ETT \#: } & \text { T11118 }\end{array}$

\begin{tabular}{|c|c|c|c|c|c|c|}
\hline \multicolumn{2}{|c}{ Reproduction at } & \multicolumn{2}{c|}{$6.25 \%$} & \multicolumn{2}{c|}{ Concentration } \\
\hline Rep. & Day 3/4 & Day 5 & Day 6 & Day 7 & Day 8 & Total \\
\hline 1 & 0 & 5 & 0 & 6 & 10 & 21 \\
\hline 2 & 0 & 5 & 0 & 7 & 10 & 22 \\
\hline 3 & 1 & 5 & 0 & 7 & 9 & 22 \\
\hline 4 & 2 & 0 & 5 & 0 & 8 & 15 \\
\hline 5 & 0 & 5 & 0 & 1 & 10 & 16 \\
\hline 6 & 0 & 5 & 0 & 3 & 10 & 18 \\
\hline 7 & 0 & 6 & 0 & 6 & 10 & 22 \\
\hline 8 & 2 & 0 & 5 & 6 & 1 & 14 \\
\hline 9 & 4 & 0 & 7 & 8 & 2 & 21 \\
\hline 10 & 3 & 0 & 7 & 8 & 1 & 19 \\
\hline
\end{tabular}

\begin{tabular}{|c|c|c|c|c|c|c|}
\hline \multicolumn{2}{|c|}{ Reproduction at } & \multicolumn{3}{c|}{$25 \%$} & \multicolumn{3}{c|}{ Concentration } \\
\hline Rep. & Day 3/4 & Day 5 & Day 6 & Day 7 & Day 8 & Total \\
\hline 1 & 0 & 0 & 8 & 0 & 9 & 17 \\
\hline 2 & 0 & 1 & 0 & 6 & 7 & 14 \\
\hline 3 & 0 & 7 & 0 & 4 & 7 & 18 \\
\hline 4 & 2 & 1 & 4 & 0 & 7 & 14 \\
\hline 5 & 0 & 6 & 0 & 2 & 8 & 16 \\
\hline 6 & 0 & 5 & 0 & 5 & 8 & 18 \\
\hline 7 & 0 & 0 & 7 & 6 & 5 & 18 \\
\hline 8 & 0 & 0 & 7 & 8 & 1 & 16 \\
\hline 9 & 1 & 0 & 6 & 0 & 8 & 15 \\
\hline 10 & 0 & 0 & 7 & 5 & 3 & 15 \\
\hline
\end{tabular}

\begin{tabular}{|c|c|c|c|c|c|c|}
\hline \multicolumn{2}{|c|}{ Reproduction at } & \multicolumn{3}{c|}{$100 \%$} & \multicolumn{2}{c|}{ Concentration } \\
\hline Rep. & Day 3/4 & Day 5 & Day 6 & Day 7 & Day 8 & Total \\
\hline 1 & 0 & 1 & 8 & 6 & 7 & 22 \\
\hline 2 & 0 & 0 & 6 & 0 & 7 & 13 \\
\hline 3 & 0 & L & L & L & L & L \\
\hline 4 & 0 & 0 & 6 & 7 & 4 & 17 \\
\hline 5 & 0 & 0 & 6 & 5 & 7 & 18 \\
\hline 6 & 0 & 0 & 6 & 4 & 5 & 15 \\
\hline 7 & 0 & 0 & 7 & 6 & 6 & 19 \\
\hline 8 & 0 & 0 & 8 & 6 & 8 & 22 \\
\hline 9 & 1 & 0 & 7 & 4 & 4 & 16 \\
\hline 10 & 0 & 0 & 8 & 4 & 4 & 16 \\
\hline
\end{tabular}




\section{CHRONIC DEFINITIVE SURVIVAL AND REPRODUCTION TEST \\ Statistical Analyses}

Client: WSRC

Sample Identification: $\quad$ CSBRP-46-02-R

Test Date: $\quad$ January 13, 1999

\begin{tabular}{|ccc|}
\hline Test for Normality & & \\
Test Used: Kolmogorov D & $\mathrm{D}=$ & 0.506 \\
& critical & 1.035 \\
& & \\
The data are normal in distribution & \\
\end{tabular}

\begin{tabular}{|c|c|c|}
\hline Test for Homogenei & & \\
\hline Test Used: Bartlett's Test & critical & $\begin{array}{l}7.61 \\
15.1\end{array}$ \\
\hline The data are I & variance & \\
\hline
\end{tabular}

\begin{tabular}{|c|c|c|c|c|c|c|}
\hline \multicolumn{7}{|c|}{ Test for Differences in Reproduction } \\
\hline \multicolumn{2}{|c|}{$\begin{array}{l}\text { Test Type Used: } \\
\text { Test Type Used: }\end{array}$} & \multicolumn{5}{|c|}{ Fishers Exact Test for Survival } \\
\hline \multirow[t]{2}{*}{ t Test } & & \multicolumn{5}{|c|}{ Test Concentration } \\
\hline & MHSF & $6.3 \%$ & $12.5 \%$ & $25.0 \%$ & $50.0 \%$ & $100 \%$ \\
\hline \multicolumn{2}{|l|}{ t Value } & 3.53 & 3.82 & 5.66 & 4.34 & 4.47 \\
\hline \multicolumn{2}{|l|}{ critical t } & 2.28 & 2.28 & 2.28 & 2.28 & 2.28 \\
\hline reproduct. & 23.8 & 19.0 & 18.6 & 16.1 & 17.9 & 17.6 \\
\hline survival & $100 \%$ & $100 \%$ & $100 \%$ & $100 \%$ & $100 \%$ & $100 \%$ \\
\hline \multirow{3}{*}{\multicolumn{2}{|c|}{$\mathrm{CV}=$}} & & & & MSD $=$ & 3.17 \\
\hline & & \multicolumn{5}{|c|}{ Test Concentration } \\
\hline & & $6.3 \%$ & $12.5 \%$ & $25.0 \%$ & $50 \%$ & $100 \%$ \\
\hline \multicolumn{7}{|l|}{ rank sum } \\
\hline \multicolumn{2}{|c|}{ critical value } & 75 & 75 & 75 & 75 & 75 \\
\hline \multirow[t]{2}{*}{$\begin{array}{l}\text { NOEC: } \\
\text { LOEC: }\end{array}$} & \multirow{2}{*}{$\begin{array}{l}\text { Survival: } \\
\text { Survival: } \\
\text { Chronic }\end{array}$} & $\begin{array}{l}>100 \% \\
>100 \%\end{array}$ & \multicolumn{2}{|c|}{$\begin{array}{l}\text { Reproduction: } \\
\text { Reproduction: }\end{array}$} & $<6.3 \%$ & \\
\hline & & Value: & Less than low & concentrat & iested & \\
\hline
\end{tabular}

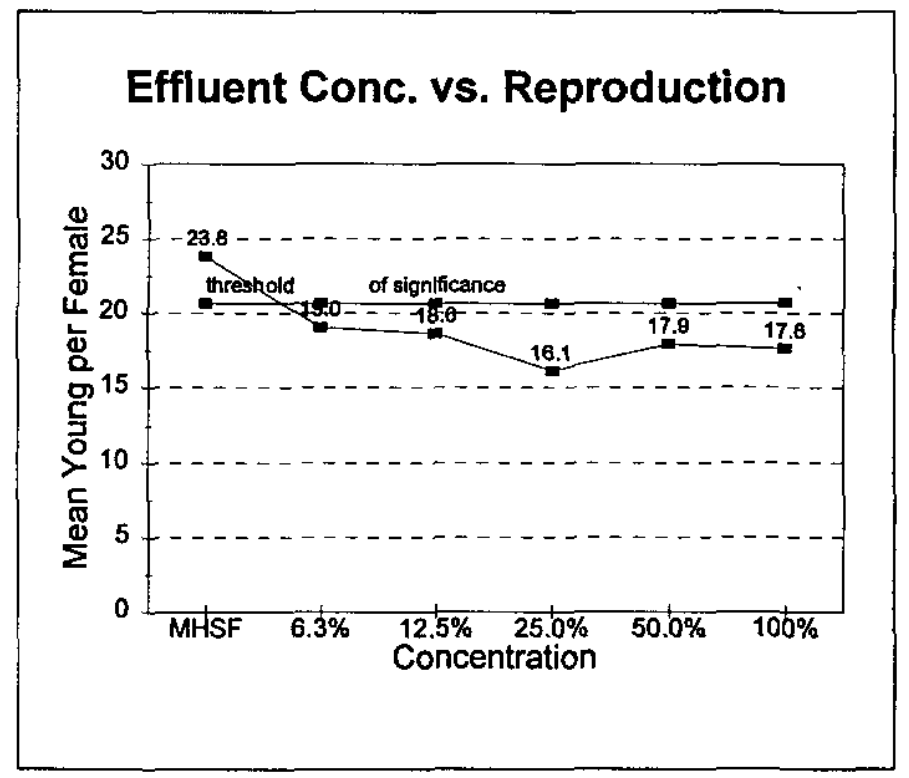

Summary

The effluent is not acutely toxic.

The effluent is chronically toxic.

Suppression of reproduction is relatively small and may be a statistical anomaly. 


\section{CHRONIC DEFINITIVE SURVIVAL AND REPRODUCTION TEST Water Chemistry}

Client: $\quad$ WSRC

Sample Identification: $\quad$ CSBRP-46-02-R

Test Date: January 13, 1999

\section{pH (After Renewal)}

\begin{tabular}{|l|r|r|r|r|r|r|}
\hline \multicolumn{7}{|c|}{ Test Concentration } \\
\hline & Control & $6.25 \%$ & $12.5 \%$ & $25 \%$ & $50 \%$ & $100 \%$ \\
\hline Initial & 7.70 & 7.55 & 7.73 & 7.48 & 7.24 & 6.63 \\
\hline Day 1 & 7.70 & 6.91 & 6.91 & 6.90 & 6.81 & 6.53 \\
\hline Day 2 & 7.79 & 8.02 & 8.06 & 8.00 & 8.00 & 7.87 \\
\hline Day 3 & 7.72 & 7.59 & 7.60 & 7.60 & 7.50 & 7.54 \\
\hline Day 4 & 7.59 & & & & & \\
\hline Day 5 & 7.75 & 7.84 & 7.73 & 7.75 & 7.73 & 7.12 \\
\hline Day 6 & 7.63 & 7.84 & 7.85 & 7.92 & 7.85 & 7.86 \\
\hline
\end{tabular}

\section{Dissolved Oxygen (After Renewal)}

\begin{tabular}{|l|r|r|r|r|r|r|}
\hline & Control & $6.25 \%$ & $12.5 \%$ & $25 \%$ & $50 \%$ & $100 \%$ \\
\hline Initial & 8.4 & 8.4 & 8.4 & 8.6 & 8.8 & 9.0 \\
\hline Day 1 & 8.3 & 8.8 & 8.8 & 8.8 & 8.7 & 8.7 \\
\hline Day 2 & 8.5 & 8.6 & 8.5 & 8.7 & 8.7 & 8.7 \\
\hline Day 3 & 8.3 & 9.2 & 9.2 & 9.0 & 9.0 & 8.9 \\
\hline Day 4 & 8.3 & & & & & \\
\hline Day 5 & 8.3 & 8.9 & 9.0 & 9.0 & 9.1 & 9.0 \\
\hline Day 6 & 8.5 & 8.4 & 8.4 & 8.5 & 8.5 & 8.4 \\
\hline
\end{tabular}

\section{pH (Before Renewal)}

\begin{tabular}{|l|r|r|r|r|r|r|}
\hline \multicolumn{7}{|c|}{ Test Concentration } \\
\hline & Control & $6.25 \%$ & $12.5 \%$ & $25 \%$ & $50 \%$ & $100 \%$ \\
\hline Day 1 & 8.10 & 8.21 & 8.09 & 8.07 & 8.04 & 8.03 \\
\hline Day 2 & 8.15 & 8.05 & 7.99 & 8.09 & 8.03 & 7.99 \\
\hline Day 3 & 8.09 & 8.16 & 8.10 & 7.98 & 8.02 & 7.82 \\
\hline Day 4 & 7.97 & & & & & \\
\hline Day 5 & 8.12 & 7.95 & 7.95 & 7.89 & 7.87 & \\
\hline Day 6 & 8.02 & 7.99 & 7.67 & 7.90 & 7.99 & 7.99 \\
\hline Final & 7.94 & 8.25 & 8.00 & 8.17 & 8.20 & 7.68 \\
\hline
\end{tabular}

\section{Dissolved Oxygen (Before Renewal)}

\begin{tabular}{|l|r|r|r|r|r|r|}
\hline & Control & $6.25 \%$ & $12.5 \%$ & $25 \%$ & $50 \%$ & $100 \%$ \\
\hline Day 1 & 8.4 & 8.9 & 8.8 & 8.7 & 8.7 & 8.6 \\
\hline Day 2 & 8.6 & 8.4 & 8.4 & 8.6 & 8.6 & 8.7 \\
\hline Day 3 & 8.6 & 8.9 & 9.0 & 9.1 & 9.2 & 9.2 \\
\hline Day 4 & 8.3 & & & & & \\
\hline Day 5 & 8.8 & 8.6 & 8.7 & 8.8 & 8.8 & \\
\hline Day 6 & 8.7 & 8.2 & 8.4 & 8.5 & 8.5 & 8.5 \\
\hline Final & 8.5 & 8.6 & 8.4 & 8.6 & 8.4 & 8.5 \\
\hline
\end{tabular}

\begin{tabular}{|c|c|c|c|c|}
\hline Date & Alkalinity & Hardness & Conductivity & Res. Cl. \\
\hline $1-11-99$ & 32 & 42.8 & 127.9 & 0.02 \\
\hline $1-13-99$ & 33.3 & 65.3 & 126.5 & 0.06 \\
\hline $1-15-99$ & 35.4 & 42.8 & 103.8 & 0.04 \\
\hline
\end{tabular}

Temperature

\begin{tabular}{|l|r|}
\hline \multicolumn{2}{|c|}{ Incubator ${ }^{\circ} \mathrm{C}$} \\
\hline Initial & 24.9 \\
\hline Day 1 & 25.0 \\
\hline Day 2 & 24.7 \\
\hline Day 3 & 25.0 \\
\hline Day 4 & 25.1 \\
\hline Day 5 & 25.0 \\
\hline Day 6 & 25.1 \\
\hline Final & 24.5 \\
\hline
\end{tabular}

Test Results Reviewed and Approved By: 


\section{Day Chronic Definitive Survival and Reproduction Bioassay Method: EPA/600/4-91/002}

Test Organism:

Ceriodaphnia dubia

Facility: WSRC

Sample ID:CSBRP-47-02-R

Aiken County

ETT\#: T11119

Sample ID: January 13, 1999 


\section{CHRONIC DEFINITIVE SURVIVAL AND REPRODUCTION TEST Survival and Reproduction Results}

Client:

Sample Identification:

Test Date:

WSRC

\section{January 13, 1999}

\begin{tabular}{|c|c|c|c|c|c|c|}
\hline \multicolumn{7}{|c|}{ Reproduction at } \\
\hline Rep. & Day 3/4 & Day 5 & Day 6 & Day 7 & Day 8 & Total \\
\hline 1 & 6 & 7 & 0 & 10 & 0 & 23 \\
\hline 2 & 0 & 0 & 8 & 12 & 0 & 20 \\
\hline 3 & 3 & 6 & 0 & 10 & 0 & 19 \\
\hline 4 & 4 & 0 & 8 & 11 & 0 & 23 \\
\hline 5 & 5 & 0 & 7 & 12 & 0 & 24 \\
\hline 6 & 0 & $X$ & $X$ & $X$ & $X$ & 0 \\
\hline 7 & 6 & 7 & 0 & 12 & 0 & 25 \\
\hline 8 & 6 & 1 & 10 & 17 & 0 & 34 \\
\hline 9 & 4 & 0 & 11 & 14 & 0 & 29 \\
\hline 10 & 0 & 1 & 0 & 0 & 0 & 1 \\
\hline
\end{tabular}

\begin{tabular}{|c|c|c|c|c|c|c|}
\hline \multicolumn{2}{|c|}{ Reproduction at } & \multicolumn{2}{c|}{$12.5 \%$} & \multicolumn{2}{c|}{ Concentration } \\
\hline Rep. & Day 3/4 & Day 5 & Day 6 & Day 7 & Day 8 & Total \\
\hline 1 & 3 & 9 & 0 & 10 & 0 & 22 \\
\hline 2 & 6 & 8 & 0 & 16 & 0 & 30 \\
\hline 3 & 4 & 9 & 0 & 16 & 0 & 29 \\
\hline 4 & 4 & 0 & 9 & 11 & 0 & 24 \\
\hline 5 & 5 & 10 & 0 & 14 & 0 & 29 \\
\hline 6 & 3 & 7 & 0 & 11 & 0 & 21 \\
\hline 7 & 6 & 9 & 0 & 14 & 0 & 29 \\
\hline 8 & 5 & 9 & 0 & 17 & 0 & 31 \\
\hline 9 & 5 & 10 & 0 & 12 & 0 & 27 \\
\hline 10 & 6 & 10 & 0 & 18 & 0 & 34 \\
\hline
\end{tabular}

\begin{tabular}{|c|c|c|c|c|c|c|}
\hline Reproduction at & \multicolumn{2}{c|}{$50 \%$} & \multicolumn{2}{c|}{ Concentration } \\
\hline Rep. & Day 3/4 & Day 5 & Day 6 & Day 7 & Day 8 & Total \\
\hline 1 & 3 & 8 & 0 & 11 & 0 & 22 \\
\hline 2 & 5 & 9 & 0 & 14 & 0 & 28 \\
\hline 3 & 5 & 7 & 0 & 12 & 0 & 24 \\
\hline 4 & 4 & 6 & 0 & 14 & 0 & 24 \\
\hline 5 & 4 & 6 & 0 & 12 & 0 & 22 \\
\hline 6 & 5 & 7 & 1 & 11 & 0 & 24 \\
\hline 7 & 5 & 6 & 0 & 14 & 0 & 25 \\
\hline 8 & 6 & 0 & 11 & 12 & 0 & 29 \\
\hline 9 & 4 & 8 & 0 & 14 & 0 & 26 \\
\hline 10 & 4 & 7 & 0 & 15 & 0 & 26 \\
\hline
\end{tabular}

$\begin{array}{ll}\text { County: } & \text { Aiken } \\ \text { NPDES\#: } & \\ \text { ETT \#: } & \mathbf{T 1 1 1 1 9}\end{array}$

\begin{tabular}{|c|c|c|c|c|c|c|}
\hline \multicolumn{2}{|c}{ Reproduction at } & \multicolumn{2}{c|}{$6.25 \%$} & \multicolumn{2}{c|}{ Concentration } \\
\hline Rep. & Day 3/4 & Day 5 & Day 6 & Day 7 & Day 8 & Total \\
\hline 1 & 4 & 9 & 0 & 16 & 0 & 29 \\
\hline 2 & 4 & 9 & 0 & 12 & 0 & 25 \\
\hline 3 & 4 & 9 & 0 & 14 & 0 & 27 \\
\hline 4 & 3 & 7 & 0 & 14 & 0 & 24 \\
\hline 5 & 4 & 0 & 9 & 14 & 0 & 27 \\
\hline 6 & 5 & 0 & 10 & 14 & 0 & 29 \\
\hline 7 & 6 & 8 & 0 & 15 & 0 & 29 \\
\hline 8 & 7 & 0 & 12 & 17 & 0 & 36 \\
\hline 9 & 5 & 10 & 0 & 14 & 0 & 29 \\
\hline 10 & 6 & 9 & 0 & 16 & 0 & 31 \\
\hline
\end{tabular}

\begin{tabular}{|c|c|c|c|c|c|c|}
\hline \multicolumn{2}{|c|}{ Reproduction at } & \multicolumn{3}{c|}{$25 \%$} & \multicolumn{3}{c|}{ Concentration } \\
\hline Rep. & Day 3/4 & Day 5 & Day 6 & Day 7 & Day 8 & Total \\
\hline 1 & 5 & 1 & 0 & 11 & 0 & 17 \\
\hline 2 & 4 & 10 & 0 & 14 & 0 & 28 \\
\hline 3 & 5 & 7 & 0 & 14 & 0 & 26 \\
\hline 4 & 5 & 7 & 0 & 15 & 0 & 27 \\
\hline 5 & 4 & 3 & 0 & 12 & 0 & 19 \\
\hline 6 & 4 & 6 & 1 & 10 & 0 & 21 \\
\hline 7 & 5 & 6 & 0 & 18 & 0 & 29 \\
\hline 8 & 5 & 0 & 3 & 10 & 0 & 18 \\
\hline 9 & 5 & 8 & 0 & 16 & 0 & 29 \\
\hline 10 & 4 & 8 & 0 & 14 & 0 & 26 \\
\hline
\end{tabular}

\begin{tabular}{|c|c|c|c|c|c|c|}
\hline \multicolumn{2}{|c|}{ Reproduction at } & \multicolumn{1}{c|}{$\mathrm{I00 \%}$} & \multicolumn{2}{c|}{ Concentration } \\
\hline Rep. & Day 3/4 & Day 5 & Day 6 & Day 7 & Day 8 & Total \\
\hline 1 & 5 & 6 & 0 & 12 & 0 & 23 \\
\hline 2 & 4 & 5 & 0 & 14 & 0 & 23 \\
\hline 3 & 4 & 6 & 0 & 11 & 0 & 21 \\
\hline 4 & 2 & 4 & 0 & 12 & 0 & 18 \\
\hline 5 & 3 & 7 & 0 & 14 & 0 & 24 \\
\hline 6 & 3 & 4 & 0 & 10 & 0 & 17 \\
\hline 7 & 4 & 7 & 0 & 14 & 0 & 25 \\
\hline 8 & 0 & 5 & 0 & 12 & 0 & 17 \\
\hline 9 & 3 & 4 & 0 & 11 & 0 & 18 \\
\hline 10 & 3 & 5 & 0 & 10 & 0 & 18 \\
\hline
\end{tabular}




\section{CHRONIC DEFINITIVE SURVIVAL AND REPRODUCTION TEST Statistical Analyses}

Client: WSRC

Sample Identification: CSBRP-47-02-R

Test Date: January 13, 1999

\begin{tabular}{|ccc|}
\hline Test for Normality & & \\
& & \\
Test Used: Kolmogorov D & D $=$ & 0.807 \\
& critical & 1.035 \\
& & \\
The data are normal in distribution & \\
\end{tabular}

\begin{tabular}{|c|c|c|}
\hline \multicolumn{3}{|c|}{ Test for Homogeneity of Variance } \\
\hline The data are no & us in varis & \\
\hline
\end{tabular}

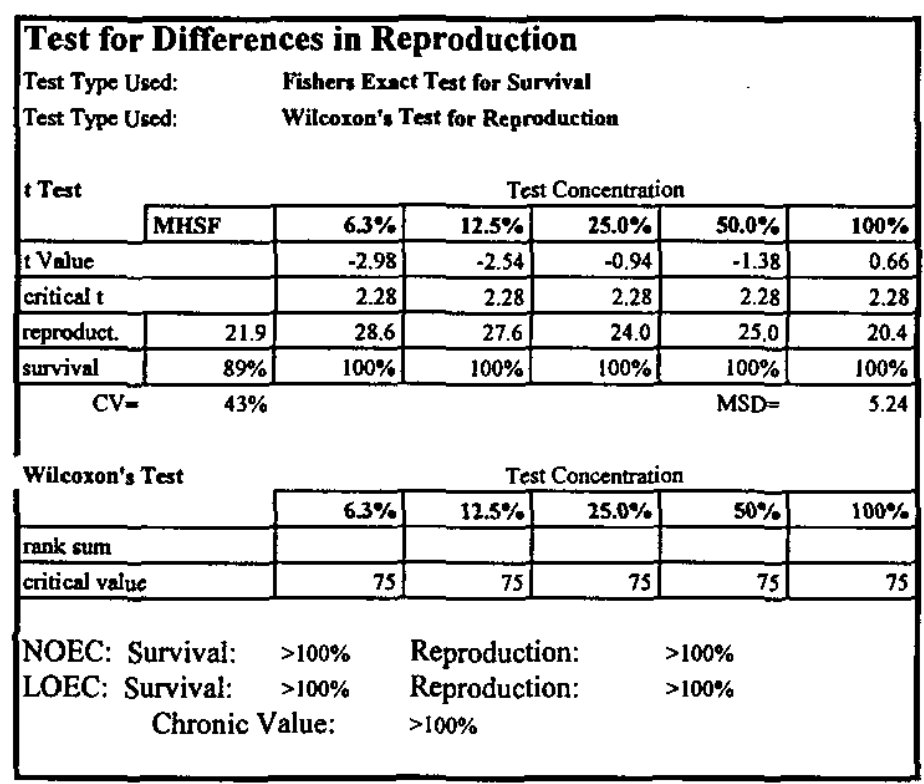

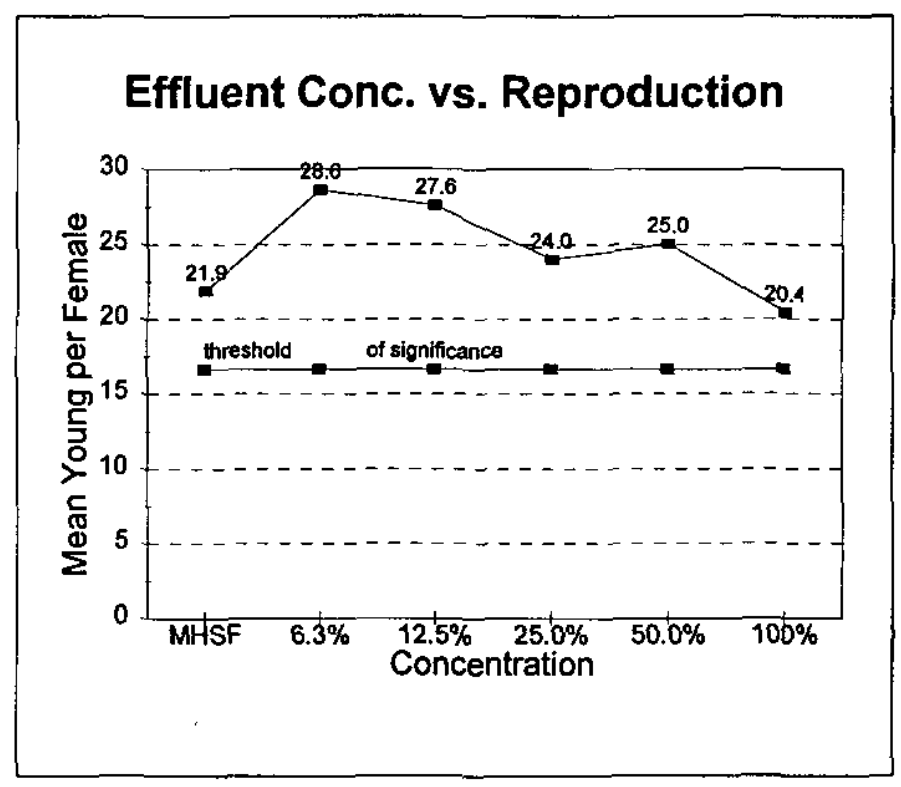

Summary

The effluent is not acutely toxic.

The effluent is not chronically toxic. 


\section{CHRONIC DEFINITIVE SURVIVAL AND REPRODUCTION TEST Water Chemistry}

Client: WSRC

Sample Identification: $\quad$ CSBRP-47-02-R

Test Date: $\quad$ January 13, 1999

pH (After Renewal)

\begin{tabular}{|l|r|r|r|r|r|r|}
\hline \multicolumn{7}{|c|}{ Test Concentration } \\
\hline & Control & $6.25 \%$ & $12.5 \%$ & $25 \%$ & $50 \%$ & $100 \%$ \\
\hline Initial & 7.70 & 7.52 & 7.91 & 7.52 & 7.88 & 6.86 \\
\hline Day 1 & 7.70 & 6.99 & 6.93 & 6.92 & 6.84 & 6.75 \\
\hline Day 2 & 7.79 & 7.99 & 8.02 & 8.04 & 8.00 & 7.73 \\
\hline Day 3 & 7.72 & 7.36 & 7.65 & 7.65 & 7.55 & 7.33 \\
\hline Day 4 & 7.59 & 7.73 & 7.76 & 7.63 & 7.65 & 7.68 \\
\hline Day 5 & 7.75 & 7.92 & 7.76 & 7.87 & 7.79 & 7.14 \\
\hline Day 6 & 7.63 & 8.00 & 7.78 & 8.03 & 7.81 & 7.79 \\
\hline
\end{tabular}

Dissolved Oxygen (After Renewal)

\begin{tabular}{|l|r|r|r|r|r|r|}
\hline & \multicolumn{7}{|c|}{ Test Concentration } \\
\hline & Control & $6.25 \%$ & $12.5 \%$ & $25 \%$ & $50 \%$ & $100 \%$ \\
\hline Initial & 8.4 & 8.5 & 8.8 & 8.7 & 8.7 & 9.1 \\
\hline Day 1 & 8.3 & 8.7 & 8.6 & 8.5 & 8.4 & 8.3 \\
\hline Day 2 & 8.5 & 8.7 & 8.8 & 8.8 & 8.8 & 8.8 \\
\hline Day 3 & 8.3 & 8.7 & 8.8 & 8.9 & 9.0 & 9.1 \\
\hline Day 4 & 8.3 & 8.7 & 8.4 & 8.9 & 9.0 & 8.9 \\
\hline Day 5 & 8.3 & 8.8 & 9.1 & 9.2 & 9.1 & 9.2 \\
\hline Day 6 & 8.5 & 8.3 & 8.4 & 8.4 & 8.5 & 8.5 \\
\hline
\end{tabular}

\section{pH (Before Renewal)}

\begin{tabular}{|l|r|r|r|r|r|r|}
\hline \multicolumn{7}{|c|}{ Test Concentration } \\
\hline & Control & $6.25 \%$ & $12.5 \%$ & $25 \%$ & $50 \%$ & $100 \%$ \\
\hline Day 1 & 8.10 & 8.08 & 8.06 & 8.04 & 8.02 & 8.00 \\
\hline Day 2 & 8.15 & 7.99 & 8.05 & 8.06 & 7.99 & 7.83 \\
\hline Day 3 & 8.09 & 7.98 & 7.86 & 8.05 & 7.99 & 7.72 \\
\hline Day 4 & 7.97 & 7.47 & 7.84 & 7.92 & 7.88 & 7.78 \\
\hline Day 5 & 8.12 & & 8.00 & 8.03 & & 7.95 \\
\hline Day 6 & 8.02 & 8.10 & 8.10 & 8.07 & 8.04 & 7.91 \\
\hline Final & 7.94 & 7.69 & 8.11 & 7.88 & 8.02 & 7.96 \\
\hline
\end{tabular}

\section{Dissolved Oxygen (Before Renewal)}

\begin{tabular}{|l|r|r|r|r|r|r|}
\hline \multicolumn{7}{|c|}{ Test Concentration } \\
\hline & Control & $6.25 \%$ & $12.5 \%$ & $25 \%$ & $50 \%$ & $100 \%$ \\
\hline Day 1 & 8.4 & 8.4 & 8.5 & 8.6 & 8.6 & 8.5 \\
\hline Day 2 & 8.6 & 8.4 & 8.5 & 8.6 & 8.6 & 8.7 \\
\hline Day 3 & 8.6 & 8.4 & 8.5 & 8.6 & 8.7 & 8.7 \\
\hline Day 4 & 8.3 & 8.7 & 8.6 & 8.7 & 8.9 & 9.2 \\
\hline Day 5 & 8.8 & & 8.7 & 8.8 & & 8.8 \\
\hline Day 6 & 8.7 & 8.4 & 8.4 & 8.5 & 8.6 & 8.6 \\
\hline Final & 8.5 & 8.2 & 8.5 & 8.2 & 8.4 & 8.4 \\
\hline
\end{tabular}

\begin{tabular}{|c|c|c|c|c|}
\hline Date & Alkalinity & Hardness & Conductivity & Res. Cl. \\
\hline $1-11-99$ & 36.2 & 77.5 & 131.3 & 0.06 \\
\hline $1-13-99$ & 35.4 & 49 & 129.9 & 0.05 \\
\hline $1-15-99$ & 29.1 & 38.8 & 116.7 & 0.03 \\
\hline
\end{tabular}

Temperature
\begin{tabular}{|l|r|}
\hline \multicolumn{2}{|c|}{ Incubator ${ }^{\circ} \mathrm{C}$} \\
\hline Initial & 24.9 \\
\hline Day 1 & 25.0 \\
\hline Day 2 & 24.7 \\
\hline Day 3 & 25.0 \\
\hline Day 4 & 25.1 \\
\hline Day 5 & 25.0 \\
\hline Day 6 & 25.1 \\
\hline Final & 24.5 \\
\hline
\end{tabular}

Test Results Reviewed and Approved By: 
7 Day Chronic Definitive Survival and Reproduction Bioassay

Method: EPA/600/4-91/002

Test Organism:

Ceriodaphnia dubia

Facility: WSRC

Sample ID:CSBRP-48-02-R

Aiken County

ETT\#: T11120

Sample ID: January 13, 1999 


\section{CHRONIC DEFINITIVE SURVIVAL AND REPRODUCTION TEST Survival and Reproduction Results}

Client:

Sample Identification:

Test Date:

WSRC

January 13, 1999

\begin{tabular}{|c|c|c|c|c|c|c|}
\hline \multicolumn{7}{|c|}{ Reproduction at } \\
\hline Rep. & Day 3/4 & Day 5 & Day 6 & Day 7 & Day 8 & Total \\
\hline 1 & 5 & 7 & 0 & 12 & 0 & 24 \\
\hline 2 & 5 & 8 & 0 & 11 & 0 & 24 \\
\hline 3 & 7 & 10 & 0 & 10 & 0 & 27 \\
\hline 4 & 0 & 0 & 8 & 11 & 0 & 19 \\
\hline 5 & 0 & 0 & 3 & 13 & 0 & 16 \\
\hline 6 & 4 & 10 & 0 & 13 & 0 & 27 \\
\hline 7 & 5 & 0 & 6 & 11 & 0 & 22 \\
\hline 8 & 0 & 4 & 0 & 15 & 0 & 19 \\
\hline 9 & 3 & 9 & 0 & 9 & 0 & 21 \\
\hline 10 & 0 & 6 & 0 & 10 & 0 & 16 \\
\hline
\end{tabular}

\begin{tabular}{|c|c|c|c|c|c|c|}
\hline \multicolumn{2}{|c|}{ Reproduction at } & \multicolumn{2}{c|}{$12.5 \%$} & \multicolumn{2}{c|}{ Concentration } \\
\hline Rep. & Day 3/4 & Day 5 & Day 6 & Day 7 & Day 8 & Total \\
\hline 1 & $L$ & $L$ & $L$ & $L$ & $L$ & $L$ \\
\hline 2 & 6 & 10 & 0 & 14 & 0 & 30 \\
\hline 3 & 5 & 9 & 0 & 11 & 0 & 25 \\
\hline 4 & 5 & 9 & 0 & 12 & 0 & 26 \\
\hline 5 & 5 & 8 & 0 & 14 & 0 & 27 \\
\hline 6 & 4 & 8 & 0 & 15 & 0 & 27 \\
\hline 7 & 4 & 0 & 10 & 14 & 0 & 28 \\
\hline 8 & 5 & 0 & 0 & 15 & 0 & 20 \\
\hline 9 & 4 & 7 & 0 & 14 & 0 & 25 \\
\hline 10 & 3 & 9 & 0 & 15 & 0 & 27 \\
\hline
\end{tabular}

\begin{tabular}{|c|c|c|c|c|c|c|}
\hline \multicolumn{2}{|c|}{ Reproduction at } & \multicolumn{3}{c|}{$50 \%$} & \multicolumn{3}{c|}{ Concentration } \\
\hline Rep. & Day 3/4 & Day 5 & Day 6 & Day 7 & Day 8 & Total \\
\hline 1 & 5 & 6 & 0 & 11 & 0 & 22 \\
\hline 2 & 5 & 10 & 0 & 12 & 0 & 27 \\
\hline 3 & 5 & 10 & 0 & 15 & 0 & 30 \\
\hline 4 & 4 & 6 & 0 & 12 & 0 & 22 \\
\hline 5 & 5 & 5 & 0 & 13 & 0 & 23 \\
\hline 6 & 4 & 6 & 0 & 11 & 0 & 21 \\
\hline 7 & 4 & 9 & 0 & 15 & 0 & 28 \\
\hline 8 & 4 & 6 & 0 & 12 & 0 & 22 \\
\hline 9 & 4 & 10 & 0 & 11 & 0 & 25 \\
\hline 10 & 4 & 5 & 0 & 12 & 0 & 21 \\
\hline
\end{tabular}

County:

NPDES\#:

ETT \#:

\begin{tabular}{|c|c|c|c|c|c|c|}
\hline \multicolumn{2}{|r|}{ Reproduction at } & \multicolumn{2}{c|}{$6.25 \%$} & \multicolumn{2}{c|}{ Concentration } \\
\hline Rep. & Day 3/4 & Day 5 & Day 6 & Day 7 & Day 8 & Total \\
\hline 1 & 4 & 8 & 0 & 14 & 0 & 26 \\
\hline 2 & 6 & 9 & 0 & 13 & 0 & 28 \\
\hline 3 & 6 & 9 & 0 & 10 & 0 & 25 \\
\hline 4 & 4 & 8 & 1 & 12 & 0 & 25 \\
\hline 5 & 5 & 7 & 1 & 13 & 0 & 26 \\
\hline 6 & 5 & 8 & 1 & 11 & 0 & 25 \\
\hline 7 & 5 & 0 & 10 & 14 & 0 & 29 \\
\hline 8 & 5 & 5 & 0 & 12 & 0 & 22 \\
\hline 9 & 4 & 9 & 0 & 10 & 0 & 23 \\
\hline 10 & 5 & 11 & 0 & 13 & 0 & 29 \\
\hline
\end{tabular}

\begin{tabular}{|c|c|c|c|c|c|c|}
\hline \multicolumn{2}{|c}{ Reproduction at } & \multicolumn{3}{c|}{$25 \%$} & \multicolumn{2}{c|}{ Concentration } \\
\hline Rep. & Day 3/4 & Day 5 & Day 6 & Day 7 & Day 8 & Total \\
\hline 1 & 4 & 9 & 0 & 9 & 0 & 22 \\
\hline 2 & 5 & 7 & 0 & 12 & 0 & 24 \\
\hline 3 & 6 & 10 & 0 & 15 & 0 & 31 \\
\hline 4 & 5 & 7 & 0 & 9 & 0 & 21 \\
\hline 5 & 5 & 6 & 0 & 11 & 0 & 22 \\
\hline 6 & 6 & 9 & 0 & 11 & 0 & 26 \\
\hline 7 & 5 & 0 & 9 & 14 & 0 & 28 \\
\hline 8 & 1 & 5 & 0 & 13 & 0 & 19 \\
\hline 9 & 5 & 6 & 0 & 13 & 0 & 24 \\
\hline 10 & 4 & 6 & 0 & 14 & 0 & 24 \\
\hline
\end{tabular}

\begin{tabular}{|c|c|c|c|c|c|c|}
\hline \multicolumn{2}{|c|}{ Reproduction at } & \multicolumn{2}{c|}{$100 \%$} & \multicolumn{2}{c|}{ Concentration } \\
\hline Rep. & Day 3/4 & Day 5 & Day 6 & Day 7 & Day 8 & Total \\
\hline 1 & 5 & 0 & 0 & 13 & 0 & 18 \\
\hline 2 & 5 & 7 & 0 & 10 & 0 & 22 \\
\hline 3 & 4 & 7 & 0 & 14 & 0 & 25 \\
\hline 4 & 6 & 7 & 0 & 9 & 0 & 22 \\
\hline 5 & 3 & 4 & 0 & 15 & 0 & 22 \\
\hline 6 & 2 & 9 & 0 & 15 & 0 & 26 \\
\hline 7 & 4 & 8 & 0 & 13 & 0 & 25 \\
\hline 8 & 0 & 4 & 0 & 12 & 0 & 16 \\
\hline 9 & 2 & 4 & 0 & 11 & 0 & 17 \\
\hline 10 & 1 & 8 & 0 & 13 & 0 & 22 \\
\hline
\end{tabular}




\section{CHRONIC DEFINITIVE SURVIVAL AND REPRODUCTION TEST \\ Statistical Analyses}

Client: WSRC

Sample Identification: CSBRP-48-02-R

Test Date: $\quad$ January 13, 1999

\begin{tabular}{|ccc|}
\hline Test for Normality & & \\
Test Used: Kolmogorov D & $\mathrm{D}=$ & 0.769 \\
& critical & 1.035 \\
& & \\
The data are normal in distribution & \\
\end{tabular}

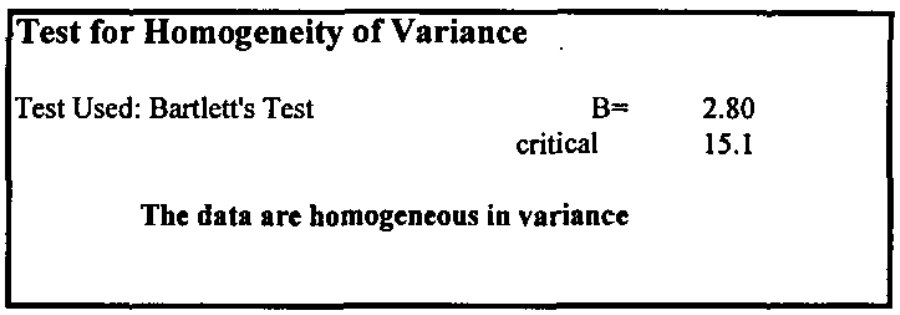

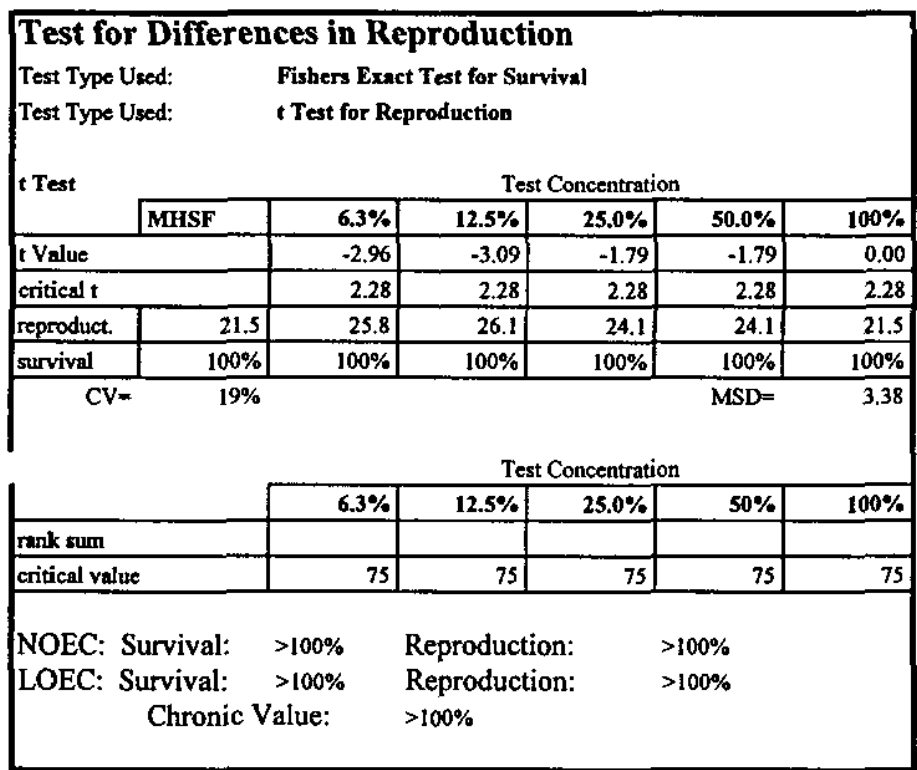

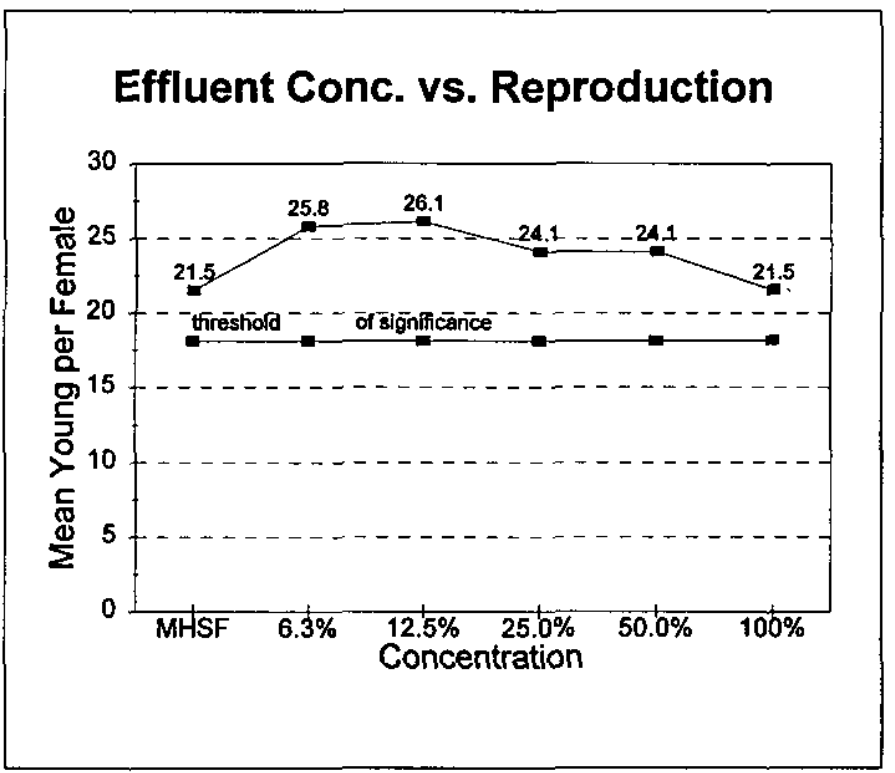

Summary

The effluent is not acutely toxic.

The effluent is not chronically toxic. 


\section{CHRONIC DEFINITIVE SURVIVAL AND REPRODUCTION TEST \\ Water Chemistry}

Client: $\quad$ WSRC

Sample Identification: $\quad$ CSBRP-48-02-R

Test Date: January 13, 1999

pH (After Renewal)

\begin{tabular}{|l|r|r|r|r|r|r|}
\hline & \multicolumn{7}{|c|}{ Test Concentration } \\
\hline & Control & $6.25 \%$ & $12.5 \%$ & $25 \%$ & $50 \%$ & $100 \%$ \\
\hline Initial & 7.70 & 7.99 & 7.37 & 7.44 & 7.63 & 6.62 \\
\hline Day 1 & 7.70 & 6.86 & 6.88 & 6.87 & 6.77 & 6.53 \\
\hline Day 2 & 7.79 & 8.27 & 8.16 & 8.08 & 7.97 & 7.94 \\
\hline Day 3 & 7.72 & 7.96 & 7.86 & 7.71 & 8.08 & 7.29 \\
\hline Day 4 & 7.59 & 7.73 & 7.75 & 7.65 & 7.50 & 7.25 \\
\hline Day 5 & 7.75 & 7.65 & 7.53 & 7.63 & 7.74 & 7.70 \\
\hline Day 6 & 7.63 & 7.96 & 8.02 & 7.97 & 7.68 & 7.69 \\
\hline
\end{tabular}

Dissolved Oxygen (After Renewal)

\begin{tabular}{|l|r|r|r|r|r|r|}
\hline \multicolumn{7}{|c|}{ Test Concentration } \\
\hline & Control & $6.25 \%$ & $12.5 \%$ & $25 \%$ & $50 \%$ & $100 \%$ \\
\hline Initial & 8.4 & 8.3 & 8.4 & 8.4 & 8.4 & 8.5 \\
\hline Day 1 & 8.3 & 8.6 & 8.6 & 8.7 & 8.6 & 8.7 \\
\hline Day 2 & 8.5 & 8.4 & 8.4 & 8.5 & 8.6 & 8.6 \\
\hline Day 3 & 8.3 & 8.6 & 8.8 & 8.9 & 8.9 & 9.0 \\
\hline Day 4 & 8.3 & 8.8 & 8.8 & 8.7 & 8.8 & 8.8 \\
\hline Day 5 & 8.3 & 8.7 & 8.7 & 8.7 & 8.8 & 8.2 \\
\hline Day 6 & 8.5 & 8.6 & 8.6 & 8.5 & 8.5 & 8.5 \\
\hline
\end{tabular}

pH (Before Renewal)

\begin{tabular}{|l|r|r|r|r|r|r|}
\hline \multicolumn{7}{|c|}{ Test Concentration } \\
\hline & Control & $6.25 \%$ & $12.5 \%$ & $25 \%$ & $50 \%$ & $100 \%$ \\
\hline Day 1 & 8.10 & 7.94 & 7.94 & 7.93 & 7.87 & 7.84 \\
\hline Day 2 & 8.15 & 8.18 & 8.19 & 8.13 & 8.05 & 7.82 \\
\hline Day 3 & 8.09 & 8.13 & 8.10 & 7.87 & 7.78 & 7.73 \\
\hline Day 4 & 7.97 & 8.03 & 7.99 & 7.99 & 8.10 & 8.06 \\
\hline Day 5 & 8.12 & 7.90 & 8.07 & 8.05 & 8.02 & 7.86 \\
\hline Day 6 & 8.02 & 8.16 & 7.93 & 8.15 & 8.09 & 7.87 \\
\hline Final & 7.94 & 8.15 & 8.02 & 8.08 & 8.10 & 7.79 \\
\hline
\end{tabular}

Dissolved Oxygen (Before Renewal)

\begin{tabular}{|l|r|r|r|r|r|r|}
\hline \multicolumn{7}{|c|}{ Test Concentration } \\
\hline & Control & $6.25 \%$ & $12.5 \%$ & $25 \%$ & $50 \%$ & $100 \%$ \\
\hline Day 1 & 8.4 & 8.5 & 8.5 & 8.6 & 8.6 & 8.6 \\
\hline Day 2 & 8.6 & 8.6 & 8.6 & 8.7 & 8.7 & 8.7 \\
\hline Day 3 & 8.6 & 9.0 & 8.9 & 9.0 & 8.9 & 8.8 \\
\hline Day 4 & 8.3 & 8.4 & 8.4 & 8.5 & 8.6 & 8.5 \\
\hline Day 5 & 8.8 & 8.6 & 8.8 & 8.9 & 8.9 & 8.9 \\
\hline Day 6 & 8.7 & 8.6 & 8.4 & 8.5 & 8.4 & 8.8 \\
\hline Final & 8.5 & 8.1 & 8.2 & 8.6 & 8.3 & 8.3 \\
\hline
\end{tabular}

\begin{tabular}{|c|c|c|c|c|}
\hline Date & Alkalinity & Hardness & Conductivity & Res. Cl. \\
\hline $1-11-99$ & 38.3 & 51 & 135.4 & $<0.01$ \\
\hline $1-13-99$ & 35.4 & 42.8 & 136.4 & 0.01 \\
\hline $1-15-99$ & 37.4 & 53 & 119.9 & 0.02 \\
\hline
\end{tabular}

Test Results Reviewed and Approved By:

Temperature
\begin{tabular}{|l|r|}
\hline \multicolumn{2}{|c|}{ Incubator ${ }^{\circ} \mathrm{C}$} \\
\hline Initial & 24.9 \\
\hline Day 1 & 25.0 \\
\hline Day 2 & 24.7 \\
\hline Day 3 & 25.0 \\
\hline Day 4 & 25.1 \\
\hline Day 5 & 25.0 \\
\hline Day 6 & 25.1 \\
\hline Final & 24.5 \\
\hline
\end{tabular}




\section{APPENDIX 2}

\section{Sediment Toxicity Test Reports}




\title{
10 DAY AMPHIPOD SEDIMENT TOXICITY TEST
}

EPA/600/R-94/024 Method 100.1

Test Organism: Hyallela azteca

\author{
Client: WSRC \\ Sample Identification: $\quad$ BKD-sed-1
}

Test Start Date: $\quad 1 / 15 / 99$ 


\section{DAY AMPHIPOD SEDIMENT TOXICITY TEST}

\begin{tabular}{|c|c|c|c|}
\hline \multirow{2}{*}{\begin{tabular}{|l|} 
Lab ID\# \\
T11117
\end{tabular}} & Client: & Start Date: & $1 / 15 / 99$ \\
\hline & Sample Identification: & End Date: & $1 / 25 / 99$ \\
\hline
\end{tabular}

\section{Test System}

EPA/600/R-94/024 Method 100.1

The test was set as a Pass/Fail test with a control treatment and one sample treatment. Each treatment replicate consisted of $100 \mathrm{~g}$ of sediment and $175 \mathrm{~mL}$ of dilution water. There were eight replicates for each treatment. Ten test organisms were placed in each replicate. Sediment from a local stream was used in the control treatment. Test organisms were fed with YCT food. The test was conducted at a temperature of $23^{\circ} \mathrm{C}$ and a light cycle of $16 \mathrm{hr}$ light $/ 8 \mathrm{hr}$ dark. Test vessels were $500 \mathrm{~mL}$ plastic beakers placed in a constant temperature incubator room.

Order: Amphipoda

\section{Test Organisms}

Species: Hyallela azteca

Source: ETT Environmental cultures

Life Stage: $\quad 7$ to 14 days old $\%$ Mortality During 48 Hr Prior to Test:: $\quad 0 \%$ Taxonomic Verification: RWK 1/15/99

Culturing: mass cultures

Observations: Cultures healthy

Acclimation: None

\begin{tabular}{|cr|}
\hline \multicolumn{2}{|c|}{ Dilution Water } \\
Type: $\quad$ Resurrection Creek & Initial \\
Collection Date 1/15/99 & $6.2 \mathrm{mg} / \mathrm{L}$ \\
Alkalinity & $8.2 \mathrm{mg} / \mathrm{L}$ \\
Hardness & 41 urmosicm \\
Conductivity & 6.16 units \\
$p H:$ & \\
& \\
Preparation Method: & \\
Grab sample & \\
& \\
\end{tabular}

\section{Control Sediment}

Source: Resurrection Creek

Collection Date: 1/15/99

Preservation: kept at $0.4^{\circ} \mathrm{C}$ in plastic

Date/Time Added to Test Chambers: 1/15/99@ IPM

Observations: mostly silt

Collection Method: grab

Disposal:

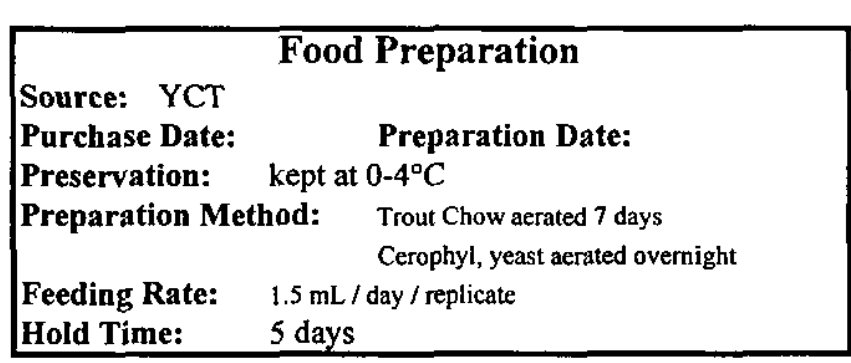

\section{Test Sediment}

Source: BKD-sed-1

Collection Date 1/11/99 Homogenized?:

Preservation: kept at $0-4^{\circ} \mathrm{C}$ in plastic

Date/Time Added to Test Chambers: $1 / 15 / 99$ @ $1 \mathrm{PM}$

Observations:

Collection Metlod: grab

Shipment: overnight

Test Chambers
Type: Plastic $500 \mathrm{~mL}$ beakers
Sediment Volume: $\quad 100 \mathrm{~mL}$
Sediment Depth $4 \mathrm{~cm}$
Overiying Water Volume: $\quad 175 \mathrm{~mL}$
Overlying Water Depth: $\quad 5 \mathrm{~cm}$
Aeration: Not needed




\title{
10 DAY AMPHIPOD SEDIMENT TOXICITY TEST
}

\begin{tabular}{|l|l|ll|}
\hline Lab ID\# & Client: $\quad$ WSRC & Start Date: & $1 / 15 / 99$ \\
\hline T11117 & Sample Identification: BKD-sed-1 & End Date: & $1 / 25 / 99$ \\
\hline
\end{tabular}

\section{WATER CHEMISTRY TEST METHODS}

Temperature: SM 18th Ed. 2550

Dissolved Oxygen: SM 18th Ed. 4500-O

pH: SM 18th Ed. 4500-H+

\author{
Alkalinity: SM 18th Ed. 2320 \\ Hardness: SM 18th Ed. 2340 \\ Conductivity: SM 18th Ed. 2510
}

\section{WATER CHEMISTRY TEST DATA - OVERLYING WATER}

CONTROL TREATMENT

\begin{tabular}{|c|c|c|c|c|c|c|}
\hline \multirow{3}{*}{$\frac{\text { Test Day }}{\text { Start }}$} & \multirow{2}{*}{$\begin{array}{c}\text { Temp. } \\
\text { C }\end{array}$} & \multirow{2}{*}{$\begin{array}{c}\mathrm{pH} \\
\text { units }\end{array}$} & \multirow{2}{*}{$\begin{array}{l}\text { D.O. } \\
\mathrm{mg} / \mathrm{L}\end{array}$} & \multirow{3}{*}{$\begin{array}{l}\text { D.O. } \\
\text { \% sat. }\end{array}$} & Alkalinity & Ammonia \\
\hline & & & & & Inipial & \multirow[t]{2}{*}{ Initial } \\
\hline & & & & & 6.2 & \\
\hline 1 & 24.0 & 6.83 & 8.5 & $99 \%$ & Final & Final \\
\hline 2 & 24.0 & 7.26 & 8.4 & $98 \%$ & 12.5 & 0.70 \\
\hline 3 & 23.7 & 7.63 & 8.4 & $98 \%$ & mgl & $\mathrm{mgh}$ \\
\hline 4 & 23.5 & 6.79 & 7.8 & $91 \%$ & Cond. & Hardness \\
\hline 5 & 23.9 & 7.70 & 8.3 & $97 \%$ & Intitial & Initiat \\
\hline 6 & 23.6 & 7.20 & 8.5 & $99 \%$ & 41 & 8.2 \\
\hline 7 & 23.2 & 7.95 & 7.4 & $86 \%$ & Final & Final \\
\hline 8 & 23.2 & 6.64 & 8.1 & $94 \%$ & & 14.3 \\
\hline 9 & 23.6 & 7.58 & 7.9 & $92 \%$ & umhos/cm & $\mathrm{mgh}$ \\
\hline 10 & & & & & Aeration: $n$ & \\
\hline
\end{tabular}

\section{SURVIVAL AND GROWTH RESULTS}

CONTROL TREATMENT

\begin{tabular}{|c|c|c|c|c|c|c|}
\hline & \multicolumn{3}{|c|}{ \# Organisms } & \multirow[b]{2}{*}{$\begin{array}{c}\% \\
\text { Survival }\end{array}$} & \multirow{2}{*}{$\begin{array}{l}\text { Mean } \\
\text { Length } \\
(\mathrm{mm})\end{array}$} & \multirow{2}{*}{$\begin{array}{l}\text { Standard } \\
\text { Deviation }\end{array}$} \\
\hline & Initial & $\begin{array}{c}\text { Live at } \\
\text { End }\end{array}$ & $\begin{array}{c}\text { Dead } \\
\text { at End }\end{array}$ & & & \\
\hline $\bar{A}$ & 10 & 10 & 0 & $100 \%$ & & \\
\hline B & 10 & 9 & 1 & $90 \%$ & & \\
\hline $\mathrm{C}$ & 10 & 8 & 2 & $80 \%$ & & \\
\hline D & 10 & 8 & 2 & $80 \%$ & & \\
\hline$E$ & 10 & 9 & 1 & $90 \%$ & & \\
\hline $\mathrm{F}$ & 10 & 8 & 2 & $80 \%$ & & \\
\hline $\mathrm{G}$ & 10 & 10 & 0 & $100 \%$ & & \\
\hline$\overline{\mathrm{H}}$ & 10 & 9 & 1 & $90 \%$ & & \\
\hline Mean & 10.0 & & & $89 \%$ & 0.00 & \\
\hline
\end{tabular}

SAMPLE TREATMENT

\begin{tabular}{|c|c|c|c|c|c|c|}
\hline \multirow[b]{2}{*}{ Test Day } & \multirow{2}{*}{$\begin{array}{c}\text { Temp. } \\
\text { C }\end{array}$} & \multirow{2}{*}{$\begin{array}{c}\mathrm{pH} \\
\text { units } \\
\end{array}$} & \multirow{2}{*}{$\begin{array}{l}\text { D.O. } \\
\mathrm{mg} / \mathrm{h}\end{array}$} & \multirow{2}{*}{$\begin{array}{c}\text { D.o. } \\
\text { \% sat. }\end{array}$} & Alkalinity & Ammonia \\
\hline & & & & & Initial & \multirow[t]{2}{*}{ Initial } \\
\hline Start & & & & & 6.2 & \\
\hline 1 & 24.0 & 6.93 & 8.5 & $99 \%$ & Final & Final \\
\hline 2 & 24.0 & 6.66 & 8.6 & $100 \%$ & 4.2 & 0.42 \\
\hline 3 & 23.7 & 7.47 & 8.3 & $97 \%$ & $\mathrm{mg} / \mathrm{L}$ & $\mathrm{mgl}$ \\
\hline 4 & 23.5 & 6.43 & 7.8 & $91 \%$ & Cond. & Hardness \\
\hline 5 & 23.9 & 7.41 & 8.2 & $95 \%$ & Initial & Initids \\
\hline 6 & 23.6 & 6.95 & 8.7 & $101 \%$ & 41 & 8.2 \\
\hline 7 & 23.2 & 7.95 & 8.4 & $98 \%$ & Final & Fingl \\
\hline 8 & 23.2 & 6.76 & 8.3 & $97 \%$ & & 4.1 \\
\hline 9 & 23.6 & 6.54 & 7.8 & $91 \%$ & umhosicm & mgl \\
\hline 10 & & & 7.9 & & Aeration: $n$ & \\
\hline
\end{tabular}

SAMPLE TREATMENT

\begin{tabular}{|c|c|c|c|c|c|c|}
\hline & \multicolumn{3}{|c|}{ \# Organisms } & \multirow[b]{2}{*}{$\begin{array}{c}\% \\
\text { Survival }\end{array}$} & \multirow{2}{*}{$\begin{array}{l}\text { Mean } \\
\text { Length } \\
\text { (mm) }\end{array}$} & \multirow{2}{*}{$\begin{array}{l}\text { Standard } \\
\text { Deviation }\end{array}$} \\
\hline & Initial & $\begin{array}{l}\text { Live at } \\
\text { End }\end{array}$ & $\begin{array}{l}\text { Dead } \\
\text { at End }\end{array}$ & & & \\
\hline$\overline{\mathrm{A}}$ & 10 & 7 & 3 & $70 \%$ & & \\
\hline B & 10 & 8 & 2 & $80 \%$ & & \\
\hline $\mathrm{C}$ & 10 & 8 & 2 & $80 \%$ & & \\
\hline D & 10 & 7 & 3 & $70 \%$ & & \\
\hline $\mathrm{E}$ & 10 & 8 & 2 & $80 \%$ & & \\
\hline $\mathrm{F}$ & 10 & 6 & 4 & $60 \%$ & & \\
\hline $\mathrm{G}$ & 10 & 8 & 2 & $80 \%$ & & \\
\hline $\overrightarrow{\mathrm{H}}$ & 10 & 8 & 2 & $80 \%$ & & \\
\hline Mean & 10.0 & & & $75 \%$ & 0.00 & \\
\hline
\end{tabular}




\section{DAY AMPHIPOD SEDIMENT TOXICITY TEST}

\begin{tabular}{|c|c|c|}
\hline \multirow{2}{*}{\begin{tabular}{|l|} 
Lab ID\# \\
T11117
\end{tabular}} & Client: & Start Date: \\
\hline & Sample Identification: & End Date: \\
\hline
\end{tabular}

RESULTS

\begin{tabular}{|c|c|c|c|c|}
\hline \multicolumn{2}{|c|}{$\begin{array}{l}\text { SURVIVAL DATA } \\
\text { Mean of Eight Replicates }\end{array}$} & \multicolumn{3}{|c|}{$\begin{array}{l}\text { GROWTH DATA } \\
\text { Mean Length (mm) }\end{array}$} \\
\hline & Mean $\%$ & & & Mean \\
\hline Control & $88.8 \%$ & Control & & NA \\
\hline Sample & $75.0 \%$ & Sample & & $\mathrm{NA}$ \\
\hline
\end{tabular}

\section{STATISTICAL ANALYSES}

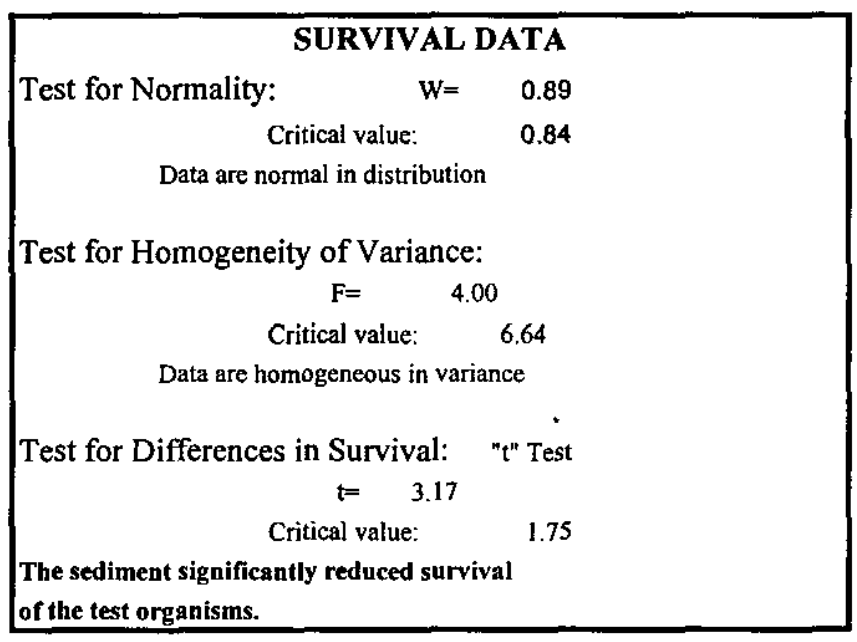

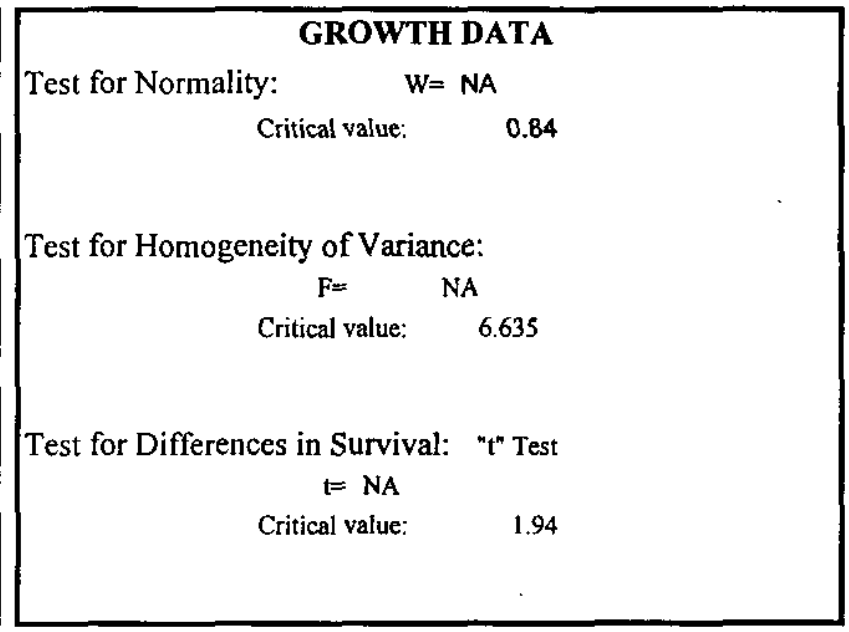

\section{COMMENTS}

None

Principal Analyst:

Report Reviewed By: Robert W. Kelley, Ph.D.

Signature:

Date:

\section{CONCLUSIONS}

The sediment does adversely affect the survival of freshwater amphipods. 


\title{
10 DAY AMPHIPOD SEDIMENT TOXICITY TEST
}

\author{
EPA/600/R-94/024 Method 100.1
}

Test Organism: Hyallela azteca

\author{
Client: WSRC \\ Sample Identification: $\quad$ CBS-45-01-R
}

Test Start Date: $\quad$ 1/15/99 


\section{DAY AMPHIPOD SEDIMENT TOXICITY TEST}

\begin{tabular}{|l|l|l|l|}
\hline Lab ID\# & Client: $\quad$ WSRC & Start Date: & $1 / 15 / 99$ \\
\cline { 2 - 5 } T11116 & Sample Identification: CBS-45-01-R & End Date: & $1 / 26 / 99$ \\
\hline
\end{tabular}

\section{Test System}

EPA/600/R-94/024 Method 100.1

The test was set as a Pass/Fail test with a control treatment and one sample treatment. Each treatment replicate consisted of $100 \mathrm{~g}$ of sediment and $175 \mathrm{~mL}$ of dilution water. There were eight replicates for each treatment. Ten test organisms were placed in each replicate. Sediment from a local stream was used in the control treatment. Test organisms were fed with YCT food. The test was conducted at a temperature of $23^{\circ} \mathrm{C}$ and a light cycle of $16 \mathrm{hr}$ light $/ 8 \mathrm{hr}$ dark. Test vessels were $500 \mathrm{~mL}$ plastic beakers placed in a constant temperature incubator room.

\begin{tabular}{|l|}
\hline \multicolumn{1}{c|}{ Test Organisms } \\
Order: Amphipoda \\
Species: Hyallela azteca \\
Source: $\quad$ ETT Environmental cultures \\
Life Stage: $\quad 7$ to 14 days old \\
\% Mortality During 48 Hr Prior to Test:: \\
Taxonomic Verification: RWK $1 / 15 / 99$ \\
Culturing: $\quad$ mass cultures \\
\\
Observations: $\quad$ Cultures healthy \\
$\begin{array}{l}\text { Acclimation: } \quad \text { None } \\
\end{array}$
\end{tabular}

\begin{tabular}{|cr|}
\hline \multicolumn{2}{|c|}{ Dilution Water } \\
Type: $\quad$ Resurrection Creek & Initial \\
Collection Date $1 / 15 / 99$ & $6.2 \mathrm{mg} / \mathrm{L}$ \\
Alkalinity & $8.2 \mathrm{mg} / \mathrm{L}$ \\
Hardness & 41 umhos/cm \\
Conductivity & 6.16 units \\
pH: & \\
Preparation Method: & \\
Grab sample & \\
\end{tabular}

Control Sediment
Source: Resurrection Creek
Collection Date: $1 / 15 / 99$
Preservation: kept at $0-4^{\circ} \mathrm{C}$ in plastic
Date/Time Added to Test Chambers: $1 / 15 / 99$ @ IPM
Observations: mostly silt
Collection Method: grab
Disposal:

Source: CBS-45-01-R

Test Sediment

Collection Date 1/11/99 Homogenized?:

Preservation: kept at $0-4^{\circ} \mathrm{C}$ in plastic

Date/Time Added to Test Chambers: 1/15/99 (a) IPM

Observations: sandy

Collection Method: grab

Shipment: overnight

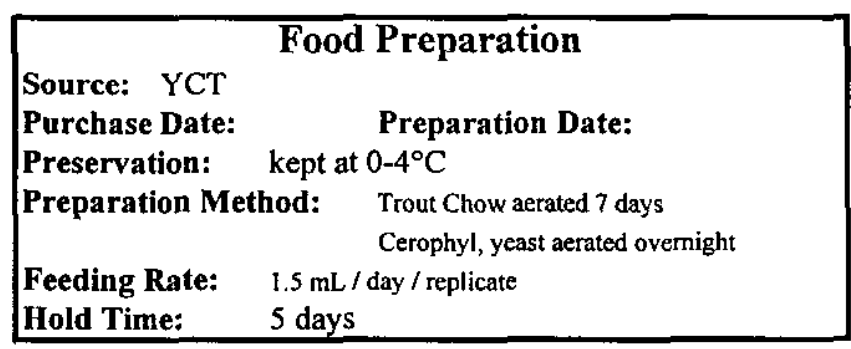

\begin{tabular}{|l|}
\hline \multicolumn{1}{c|}{ Test Chambers } \\
Type: Plastic $500 \mathrm{~mL}$ beakers \\
Sediment Volume: $\quad 100 \mathrm{~mL}$ \\
Sediment Depth $4 \mathrm{~cm}$ \\
Overlying Water Volume: $\quad 175 \mathrm{~mL}$ \\
Overlying Water Depth: $\quad 5 \mathrm{~cm}$ \\
Aeration: Not needed \\
\hline
\end{tabular}




\section{DAY AMPHIPOD SEDIMENT TOXICITY TEST}

\begin{tabular}{|l|l|l|l|}
\hline Lab ID\# & Client: $\quad$ WSRC & Start Date: & 1/15/99 \\
\cline { 2 - 4 } & Sample Identification: $\quad$ CBS-45-01-R & End Date: & 1/26/99 \\
\hline
\end{tabular}

\section{WATER CHEMISTRY TEST METHODS}

\begin{tabular}{|l|l|}
\hline Temperature: SM 18th Ed. 2550 & Alkalinity: SM 18th Ed. 2320 \\
Dissolved Oxygen: SM 18th Ed. 4500-O & Hardness: SM 18th Ed. 2340 \\
pH: SM 18th Ed. 4500-H+ & Conductivity: SM 18th Ed. 2510 \\
\hline
\end{tabular}

\section{WATER CHEMISTRY TEST DATA - OVERLYING WATER}

CONTROL TREATMENT

\begin{tabular}{|c|c|c|c|c|c|c|}
\hline & Temp. & $\mathrm{pH}$ & D.O. & D.O. & Alkalinity & Ammonia \\
\hline Test Day & C & units & $\mathrm{mg} / \mathrm{L}$ & $\%$ sat. & Initial & Initial \\
\hline Start & & & & & 6.2 & \\
\hline 1 & 24.0 & 6.83 & 8.5 & $99 \%$ & Final & Final \\
\hline 2 & 24.0 & 7.26 & 8.4 & $98 \%$ & 12.5 & 0.70 \\
\hline 3 & 23.7 & 7.63 & 8.4 & $98 \%$ & $m g h$ & $m g h$ \\
\hline 4 & 23.5 & 6.79 & 7.8 & $91 \%$ & Cond. & Hardness \\
\hline 5 & 23.9 & 7.70 & 8.3 & $97 \%$ & Initual & Intitial \\
\hline 6 & 23.6 & 7.20 & 8.5 & $99 \%$ & 41 & 8.2 \\
\hline 7 & 23.2 & 7.95 & 7.4 & $86 \%$ & Final & Final \\
\hline 8 & 23.2 & 6.64 & 8.1 & $94 \%$ & & 14.3 \\
\hline 9 & 23.6 & 7.58 & 7.9 & $92 \%$ & umhos/cm & $\mathrm{mgh}$ \\
\hline 10 & & & & & \multicolumn{2}{|c|}{ Aeration: none } \\
\hline
\end{tabular}

\section{SURVIVAL AND GROWTH RESULTS}

CONTROL TREATMENT

\begin{tabular}{|c|c|c|c|c|c|c|}
\hline & & rganism & & & Mean & Standard \\
\hline & Initial & $\begin{array}{c}\text { Live at } \\
\text { End }\end{array}$ & $\begin{array}{l}\text { Dead } \\
\text { at End }\end{array}$ & $\begin{array}{c}\% \\
\text { Survival }\end{array}$ & $\begin{array}{l}\text { Length } \\
(\mathrm{mm})\end{array}$ & Deviation \\
\hline $\mathrm{A}$ & 10 & 10 & $\overline{0}$ & $100 \%$ & & \\
\hline B & 10 & 9 & 1 & $90 \%$ & & \\
\hline $\mathrm{C}$ & 10 & 8 & 2 & $80 \%$ & & \\
\hline D & 10 & 8 & 2 & $80 \%$ & & \\
\hline$E$ & 10 & 9 & 1 & $90 \%$ & & \\
\hline$F$ & 10 & 8 & 2 & $80 \%$ & & \\
\hline $\mathrm{G}$ & 10 & 10 & 0 & $100 \%$ & & \\
\hline $\mathrm{H}$ & 10 & 9 & 1 & $90 \%$ & & \\
\hline Mean & 10.0 & & & $89 \%$ & 0.00 & \\
\hline
\end{tabular}

\begin{tabular}{|l|r|r|r|r|l|l|}
\hline & \multicolumn{7}{|c|}{ \# Organisms } & Mean & Standard \\
& Initial & $\begin{array}{c}\text { Live at } \\
\text { End }\end{array}$ & $\begin{array}{c}\text { Dead } \\
\text { at End }\end{array}$ & $\begin{array}{c}\% \\
\text { Survival }\end{array}$ & $\begin{array}{l}\text { Length } \\
\text { (mm) }\end{array}$ & Deviation \\
\hline A & 10 & 7 & 3 & $70 \%$ & & \\
\hline B & 10 & 6 & 4 & $60 \%$ & & \\
\hline C & 10 & 8 & 2 & $80 \%$ & & \\
\hline D & 10 & 5 & 5 & $50 \%$ & & \\
\hline E & 10 & 7 & 3 & $70 \%$ & & \\
\hline F & 10 & 7 & 3 & $70 \%$ & & \\
\hline G & 10 & 8 & 2 & $80 \%$ & & \\
\hline H & 10 & 7 & 3 & $70 \%$ & & \\
\hline Mean & 10.0 & & & $69 \%$ & 0.00 & \\
\hline
\end{tabular}

SAMPLE TREATMENT

\begin{tabular}{|c|c|c|c|c|c|c|}
\hline \multirow[b]{2}{*}{ Test Day } & \multirow{2}{*}{$\begin{array}{c}\text { Temp. } \\
\text { C }\end{array}$} & \multirow{2}{*}{$\begin{array}{c}\mathrm{pH} \\
\text { units }\end{array}$} & \multirow{2}{*}{$\begin{array}{l}\mathrm{D} . \mathrm{O} . \\
\mathrm{mg} / \mathrm{L}\end{array}$} & \multirow{2}{*}{$\begin{array}{l}\text { D.O. } \\
\text { \% sat. }\end{array}$} & Alkalinity & Ammonia \\
\hline & & & & & Initial & \multirow[t]{2}{*}{ Initial } \\
\hline Start & & & & & 6.2 & \\
\hline 1 & 24.0 & 7.36 & 8.3 & $97 \%$ & Final & Find \\
\hline 2 & 24.0 & 7.11 & 8.4 & $98 \%$ & 25.0 & 0.10 \\
\hline 3 & 23.7 & 7.96 & 8.5 & $99 \%$ & $\mathrm{mgl}$ & mgl. \\
\hline 4 & 23.5 & 6.73 & 8.2 & $95 \%$ & Cond. & Hardness \\
\hline 5 & 23.9 & 7.17 & 8.2 & $95 \%$ & Initial & Initive \\
\hline 6 & 23.6 & 7.45 & 8.6 & $100 \%$ & 41 & 8.2 \\
\hline 7 & 23.2 & 7.67 & 7.8 & $91 \%$ & Final & Final \\
\hline 8 & 23.2 & 7.26 & 8.6 & $100 \%$ & & 18.4 \\
\hline 9 & 23.6 & 7.92 & 7.2 & $84 \%$ & umhos/cm & $\mathrm{mgh}$. \\
\hline 10 & & & & & Aeratior & \\
\hline
\end{tabular}




\section{DAY AMPHIPOD SEDIMENT TOXICITY TEST}

\begin{tabular}{|l|l|ll|}
\hline Lab ID\# & Client: $\quad$ WSRC & Start Date: & $1 / 15 / 99$ \\
\cline { 2 - 5 } T11116 & Sample Identification: CBS-45-01-R & End Date: & $1 / 26 / 99$ \\
\hline
\end{tabular}

\section{RESULTS}

\begin{tabular}{|c|c|c|c|c|}
\hline \multicolumn{2}{|c|}{$\begin{array}{l}\text { SURVIVAL DATA } \\
\text { Mean of Eight Replicates }\end{array}$} & \multirow{2}{*}{\multicolumn{2}{|c|}{$\begin{array}{l}\text { GROWTH DATA } \\
\text { Mean Length (mm) }\end{array}$}} & \\
\hline & Mean \% & & & Mean \\
\hline Control & $88.8 \%$ & Control & & NA \\
\hline Sample & $68.8 \%$ & Sample & & NA \\
\hline
\end{tabular}

STATISTICAL ANALYSES

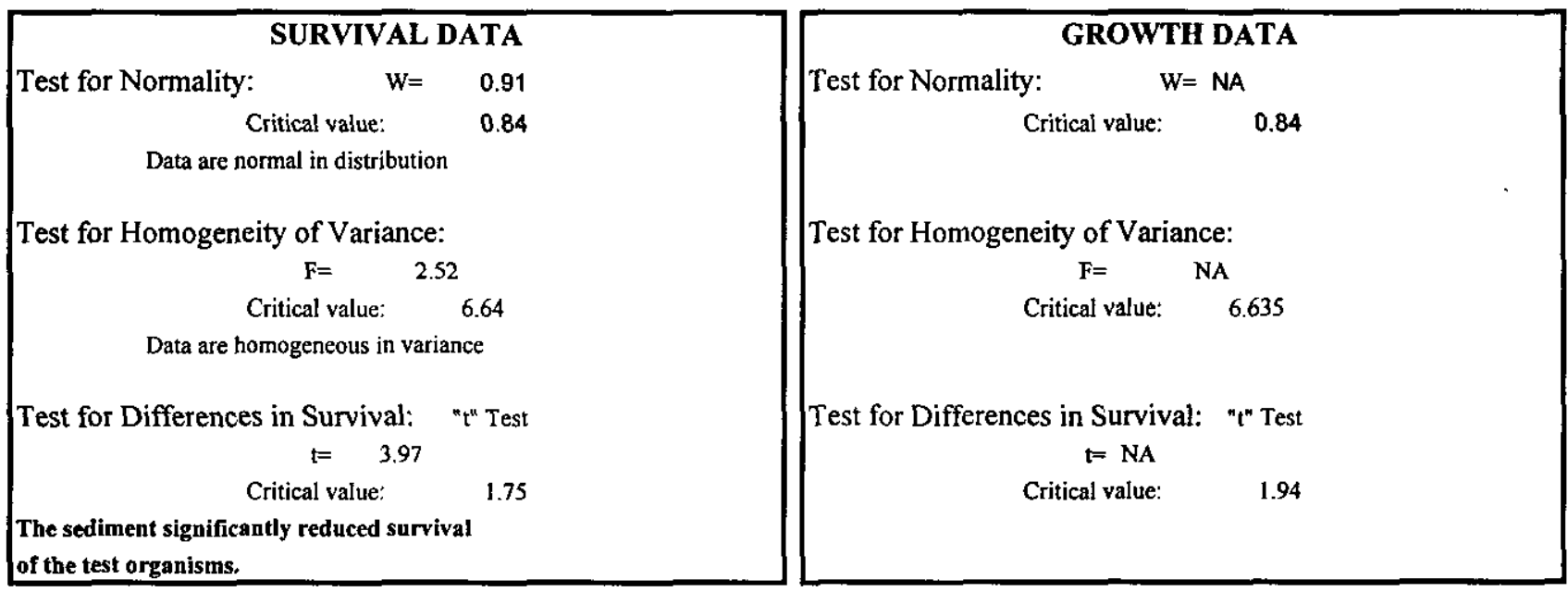

\section{COMMENTS}

None

Principal Analyst:

Report Reviewed By: Robert W. Kelley, Ph.D.

$\begin{array}{ll}\text { Signature: } & \text { Date: } \\ \text { Signature: } & \text { Date: }\end{array}$

CONCLUSIONS

The sediment does adversely affect the survival of freshwater amphipods. 


\title{
10 DAY AMPHIPOD SEDIMENT TOXICITY TEST
}

\author{
EPA/600/R-94/024 Method 100.1 \\ Test Organism: Hyallela azteca
}

\author{
Client: WSRC \\ Sample Identification: $\quad$ CSB-46-01-R
}

Test Start Date: $\quad 1 / 15 / 99$ 


\section{DAY AMPHIPOD SEDIMENT TOXICITY TEST}

\begin{tabular}{|c|c|c|}
\hline \multirow{2}{*}{$\begin{array}{l}\text { Lab ID\# } \\
\text { T11113 }\end{array}$} & Client: & Start Date: $\quad 1 / 15 / 99$ \\
\hline & Sample Identification: & End Date: \\
\hline
\end{tabular}

\section{Test System}

EPA/600/R-94/024 Method 100.1

The test was set as a Pass/Fail test with a control treatment and one sample treatment. Each treatment replicate consisted of $100 \mathrm{~g}$ of sediment and $175 \mathrm{~mL}$ of dilution water. There were eight replicates for each treatment. Ten test organisms were placed in each replicate. Sediment from a local stream was used in the control treatment. Test organisms were fed with YCT food. The test was conducted at a temperature of $23^{\circ} \mathrm{C}$ and a light cycle of $16 \mathrm{hr}$ light/ $8 \mathrm{hr}$ dark. Test vessels were $500 \mathrm{~mL}$ plastic beakers placed in a constant temperature incubator room.

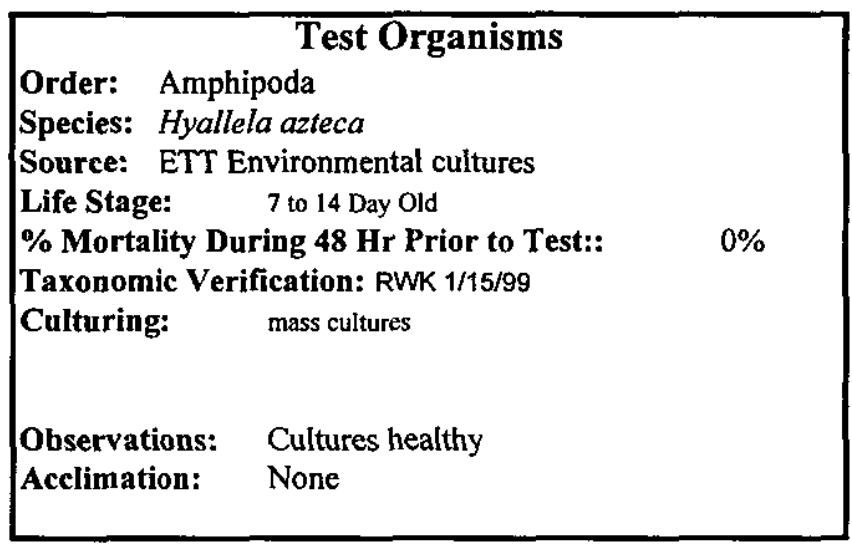

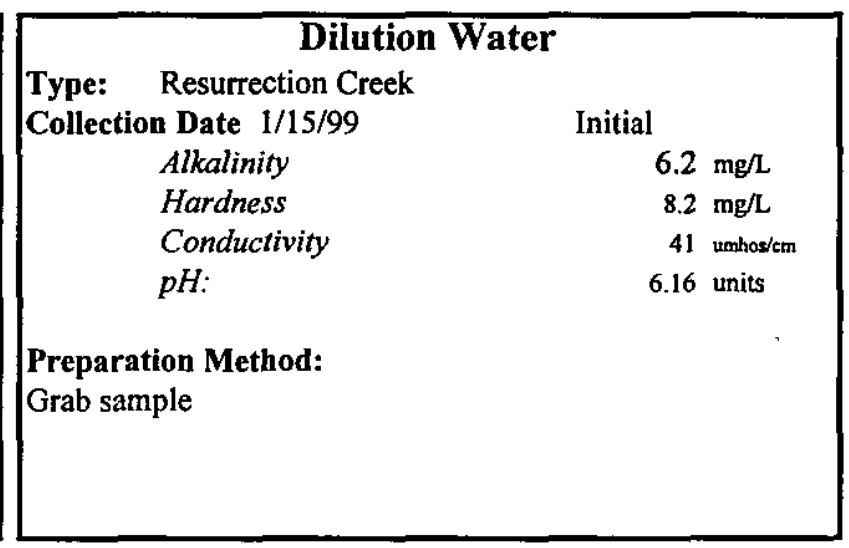

Control Sediment
Source: Resurrection Creek
Collection Date: $1 / 15 / 99$
Preservation: kept at $0-4^{\circ} \mathrm{C}$ in plastic
Date/Time Added to Test Chambers: $1 / 15 / 99 @ \mathrm{IPM}$
Observations: mostly silt
Collection Method: grab
Disposal:

Test Sediment
Source: CSB-46-01-R
Collection Date $1 / 11 / 99 \quad$ Homogenized?:
Preservation: kept at $0-4^{\circ} \mathrm{C}$ in plastic
Date/Time Added to Test Chambers: $1 / 15 \mathrm{Ng} @$ IPM
Observations: sandy
Collection Method: grab
Shipment: overnight

\begin{tabular}{|l|l|}
\hline & Food Preparation \\
Source: YCT & \multicolumn{1}{c|}{ Preparation Date: } \\
Purchase Date: & kept at $0-4^{\circ} \mathrm{C}$ \\
Preservation: & Trout Chow aerated 7 days \\
Preparation Method: $\quad$ Cerophyl, yeast aerated overnight & \\
Feeding Rate: & $1.5 \mathrm{~mL} /$ day $/$ replicate \\
Hold Time: & 5 days \\
\hline
\end{tabular}

\section{Test Chambers}

Type: Plastic $500 \mathrm{~mL}$ beakers Sediment Volume: $\quad 100 \mathrm{~mL}$ Sediment Depth $4 \mathrm{~cm}$ Overlying Water Volume: $175 \mathrm{~mL}$ Overlying Water Depth: $5 \mathrm{~cm}$ Aeration: Not needed 


\section{DAY AMPHIPOD SEDIMENT TOXICITY TEST}

\begin{tabular}{|c|c|c|c|c|}
\hline \multirow{2}{*}{$\begin{array}{l}\text { Lab ID\# } \\
\text { T11 } 113\end{array}$} & \multicolumn{2}{|l|}{ Client: } & Start Date: & $1 / 15 / 99$ \\
\hline & Sample Identification: & CSB-46-01-R & End Date: & $1 / 25 / 99$ \\
\hline \multicolumn{5}{|c|}{ WATER CHEMISTRY TEST METHODS } \\
\hline \multicolumn{3}{|c|}{$\begin{array}{l}\text { Temperature: SM 18th Ed. } 2550 \\
\text { Dissolved Oxygen: SM 18th Ed. } 4500-\mathrm{O} \\
\text { pH: SM 18th Ed. } 4500-\mathrm{H}+\end{array}$} & \multicolumn{2}{|c|}{$\begin{array}{l}\text { Alkalinity: SM 18th Ed. } 2320 \\
\text { Hardness: SM 18th Ed. } 2340 \\
\text { Conductivity: SM 18th Ed. } 2510\end{array}$} \\
\hline
\end{tabular}

\section{WATER CHEMISTRY TEST DATA - OVERLYING WATER}

CONTROL TREATMENT

\begin{tabular}{|c|c|c|c|c|c|c|}
\hline & Temp. & $\mathrm{pH}$ & D.o. & D.O. & Alkalinity & Ammonia \\
\hline Test Day & $\mathrm{C}$ & units & $\mathrm{mg} / \mathrm{L}$ & $\%$ sat. & Initial & Initial \\
\hline Start & & & & & 6.2 & \\
\hline 1 & 24.0 & 6.83 & 8.5 & $99 \%$ & Final & Final \\
\hline 2 & 24.0 & 7.26 & 8.4 & $98 \%$ & 12.5 & 0.70 \\
\hline 3 & 23.7 & 7.63 & 8.4 & $98 \%$ & $m g h$ & $m g n$ \\
\hline 4 & 23.5 & 6.79 & 7.8 & $91 \%$ & Cond. & Hardness \\
\hline 5 & 23.9 & 7.70 & 8.3 & $97 \%$ & Initial & Initial \\
\hline 6 & 23.6 & 7.20 & 8.5 & $99 \%$ & 41 & 8.2 \\
\hline 7 & 23.2 & 7.95 & 7.4 & $86 \%$ & Final & Final \\
\hline 8 & 23.2 & 6.64 & 8.1 & $94 \%$ & & 14.3 \\
\hline 9 & 23.6 & 7.58 & 7.9 & $92 \%$ & umhos/cm & $\mathrm{mgh}$ \\
\hline 10 & & & & & \multicolumn{2}{|c|}{ Aeration: none } \\
\hline
\end{tabular}

SAMPLE TREATMENT

\begin{tabular}{|c|c|c|c|c|c|c|}
\hline \multirow{3}{*}{$\frac{\text { Test Day }}{\text { Start }}$} & \multirow{2}{*}{$\begin{array}{c}\text { Temp. } \\
\mathrm{C}\end{array}$} & \multirow{2}{*}{$\begin{array}{c}\mathrm{pH} \\
\text { units }\end{array}$} & \multirow{2}{*}{$\begin{array}{l}\mathrm{D} .0 \\
\mathrm{mg} / \mathrm{L}\end{array}$} & \multirow{2}{*}{$\begin{array}{c}\text { D.O. } \\
\text { \% sat. }\end{array}$} & Alkalinity & Ammonia \\
\hline & & & & & Initial & \multirow[t]{2}{*}{ Initiv } \\
\hline & & & & & 6.2 & \\
\hline 1 & 24.0 & 7.23 & 8.2 & $95 \%$ & Final & Final \\
\hline 2 & 24.0 & 6.94 & 8.4 & $98 \%$ & 14.5 & 0.21 \\
\hline 3 & 23.7 & 6.96 & 8.4 & $98 \%$ & $\mathrm{mgh}$ & $\mathrm{mgh}$ \\
\hline 4 & 23.5 & 6.79 & 8.1 & $94 \%$ & Cond. & Hardriess \\
\hline 5 & 23.9 & 7.40 & 8.2 & $95 \%$ & Initid & Innitial \\
\hline 6 & 23.6 & 7.26 & 8.6 & $100 \%$ & 41 & 8.2 \\
\hline 7 & 23.2 & 7.34 & 8.0 & $93 \%$ & Final & Finnal \\
\hline 8 & 23.2 & 6.96 & 8.6 & $100 \%$ & & 12.2 \\
\hline 9 & 23.6 & 7.37 & 7.8 & $91 \%$ & umhos/cm & mgh \\
\hline 10 & & & & & Aeration & \\
\hline
\end{tabular}

\section{SURVIVAL AND GROWTH RESULTS}

CONTROL TREATMENT

\begin{tabular}{|c|c|c|c|c|c|c|}
\hline & \# & $\begin{array}{l}\text { rganisn } \\
\text { Live at } \\
\text { End }\end{array}$ & $\begin{array}{l}\text { 1S } \\
\text { Dead } \\
\text { at End }\end{array}$ & $\begin{array}{c}\% \\
\text { Survival }\end{array}$ & $\begin{array}{l}\text { Mean } \\
\text { Length } \\
(\mathrm{mm})\end{array}$ & $\begin{array}{l}\text { Standard } \\
\text { Deviation }\end{array}$ \\
\hline A & 10 & 10 & 0 & $100 \%$ & & \\
\hline$B$ & 10 & 9 & 1 & $90 \%$ & & \\
\hline $\mathrm{C}$ & 10 & 8 & 2 & $80 \%$ & & \\
\hline D & 10 & 8 & 2 & $80 \%$ & & \\
\hline $\mathbf{E}$ & 10 & 9 & 1 & $90 \%$ & & \\
\hline$F$ & 10 & 8 & 2 & $80 \%$ & & \\
\hline $\mathrm{G}$ & 10 & 10 & 0 & $100 \%$ & & \\
\hline $\mathrm{H}$ & 10 & 9 & 1 & $90 \%$ & & \\
\hline Mean & 10.0 & & & $89 \%$ & 0.00 & \\
\hline
\end{tabular}

SAMPLE TREATMENT

\begin{tabular}{|c|c|c|c|c|c|c|}
\hline & Initial & $\begin{array}{l}\text { Organis } \\
\text { Live at } \\
\text { End }\end{array}$ & \begin{tabular}{|l|} 
ns \\
Dead \\
at End
\end{tabular} & $\begin{array}{c}\% \\
\text { Survival }\end{array}$ & $\begin{array}{l}\text { Mean } \\
\text { Length } \\
(\mathrm{mm})\end{array}$ & $\begin{array}{l}\text { Standard } \\
\text { Deviation }\end{array}$ \\
\hline A & 10 & $\mathrm{~N} / \mathrm{A}$ & $\mathrm{N} / \mathrm{A}$ & NA & & \\
\hline$B$ & 10 & 8 & 2 & $80 \%$ & & \\
\hline$C$ & 10 & 7 & 3 & $70 \%$ & & \\
\hline D & 10 & 9 & 1 & $90 \%$ & & \\
\hline $\mathrm{E}$ & 10 & 7 & 3 & $70 \%$ & & \\
\hline $\mathrm{F}$ & 10 & 6 & 4 & $60 \%$ & & \\
\hline $\bar{G}$ & 10 & 10 & 0 & $100 \%$ & & \\
\hline $\mathrm{H}$ & 10 & 10 & 0 & $100 \%$ & & \\
\hline Mean & 10.0 & & & $81 \%$ & 0.00 & \\
\hline
\end{tabular}




\section{DAY AMPHIPOD SEDIMENT TOXICITY TEST}

\begin{tabular}{|c|c|c|}
\hline \multirow{2}{*}{$\begin{array}{l}\text { Lab ID\# } \\
\text { T11113 }\end{array}$} & Client: & Start Date: $\quad 1 / 15 / 99$ \\
\hline & Sample Identification: & End Date: \\
\hline
\end{tabular}

\section{RESULTS}

\begin{tabular}{|l|r|}
\hline \multicolumn{2}{|c|}{$\begin{array}{c}\text { SURVIVAL DATA } \\
\text { Mean of Eight Replicates }\end{array}$} \\
\cline { 2 - 2 } & Mean \% \\
\hline Control & $88.8 \%$ \\
\hline Sample & $81.4 \%$ \\
\hline
\end{tabular}

\begin{tabular}{|l|l|}
\hline \multicolumn{2}{|c|}{$\begin{array}{c}\text { GROWTH DATA } \\
\text { Mean Length }(\mathrm{mm})\end{array}$} \\
\cline { 2 - 2 } & \\
\cline { 2 - 2 } & Mean \\
\hline Control & NA \\
\hline Sample & NA \\
\hline
\end{tabular}

\section{STATISTICAL ANALYSES}

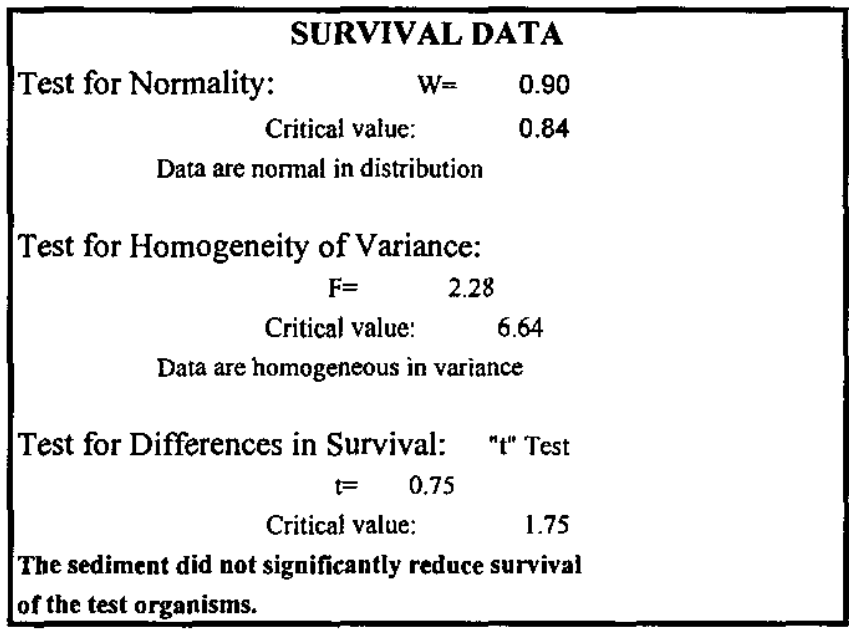

\begin{tabular}{|} 
Test for Normality: $\quad$ WROWTH DATA \\
Critical value: $\quad 0.84$ \\
Data are not normal in distribution \\
Test for Homogeneity of Variance: \\
$\mathrm{F}=\quad$ NA \\
Critical value: $\quad 6.635$ \\
Data are homogeneous in variance \\
Test for Differences in Survival: " $\mathrm{t}$ " Test \\
$\mathrm{t}=$ NA \\
Critical value:
\end{tabular}

\section{COMMENTS}

None

Principal Analyst:

Report Reviewed By: Robert W. Kelley, Ph.D.

$\begin{array}{ll}\text { Signature: } & \text { Date: } \\ \text { Signature: } & \text { Date: }\end{array}$

\section{CONCLUSIONS}

The sediment does adversely affect the survival of freshwater amphipods.

$$
\text { A }
$$




\title{
10 DAY AMPHIPOD SEDIMENT TOXICITY TEST
}

\author{
EPA/600/R-94/024 Method 100.1
}

Test Organism: Hyallela azteca

\author{
Client: WSRC \\ Sample Identification: CBS-47-01-R
}

Test Start Date: $\quad 1 / 15 / 99$ 


\section{DAY AMPHIPOD SEDIMENT TOXICITY TEST}

\begin{tabular}{|l|l|ll|}
\hline Lab ID\# & Client: $\quad$ WSRC & Start Date: & 1/15/99 \\
\cline { 2 - 3 } & Sample Identification: $\quad$ CBS-47-01-R & End Date: & 1/25/99 \\
\hline
\end{tabular}

\section{Test System}

EPA/600/R-94/024 Method 100.1

The test was set as a Pass/Fail test with a control treatment and one sample treatment. Each treatment replicate consisted of $100 \mathrm{~g}$ of sediment and $175 \mathrm{~mL}$ of dilution water. There were eight replicates for each treatment. Ten test organisms were placed in each replicate. Sediment from a local stream was used in the control treatment. Test organisms were fed with YCT food. The test was conducted at a temperature of $23^{\circ} \mathrm{C}$ and a light cycle of $16 \mathrm{hr}$ light/ $8 \mathrm{hr}$ dark. Test vessels were $500 \mathrm{~mL}$ plastic beakers placed in a constant temperature incubator room.

\begin{tabular}{|c|c|c|}
\hline \multicolumn{3}{|c|}{ Test Organisms } \\
\hline $\begin{array}{l}\text { Order: Amph } \\
\text { Species: Hyall } \\
\text { Source: ETT } \\
\text { Life Stage: } \\
\text { \% Mortality Di } \\
\text { Taxonomic Ver } \\
\text { Culturing: }\end{array}$ & $\begin{array}{l}\text { ipoda } \\
\text { ela azteca } \\
\text { invironmental cultures } \\
7 \text { to } 14 \text { days old } \\
\text { uring } 48 \text { Hr Prior to Test:: } \\
\text { ification: RWK } 1 / 15 / 99 \\
\text { mass cultures }\end{array}$ & $0 \%$ \\
\hline $\begin{array}{l}\text { Observations: } \\
\text { Acclimation: }\end{array}$ & $\begin{array}{l}\text { Cultures healthy } \\
\text { None }\end{array}$ & \\
\hline
\end{tabular}

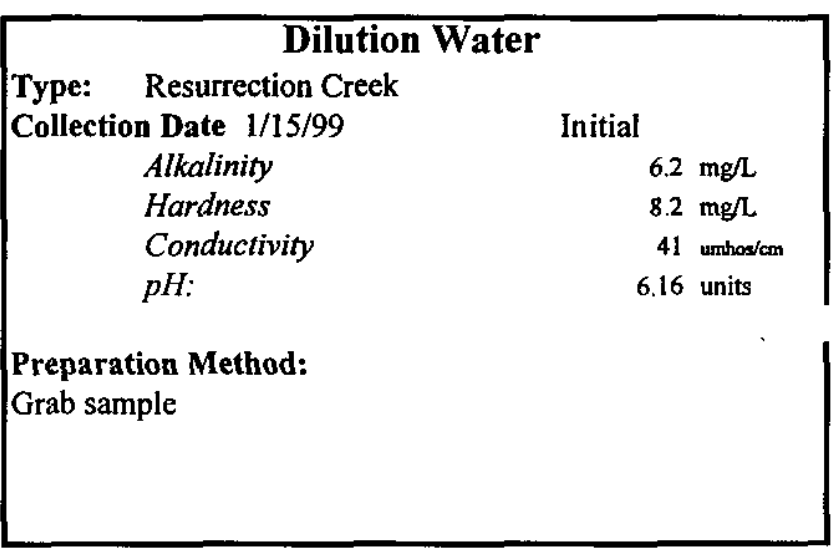

Source: Resurrection Creek

\section{Control Sediment}

Collection Date: $1 / 15 / 99$

Preservation: kept at $0-4^{\circ} \mathrm{C}$ in plastic

Date/Time Added to Test Chambers: 1/1/1/9 @ IPM

Observations: mostly silt

Collection Method: grab

Disposal:

\section{Test Sediment}

Source: CBS-47-01-R

Collection Date 1/11/99 Homogenized?:

Preservation: kept at $0-4^{\circ} \mathrm{C}$ in plastic

Date/Time Added to Test Chambers: 1/15/99 (6) IPM

Observations: sandy

Collection Method: grab

Shipment: overnight

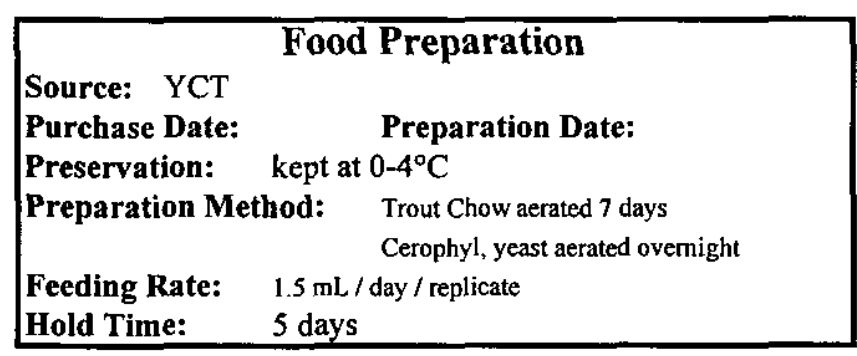

\begin{tabular}{l} 
Test Chambers \\
Type: Plastic $500 \mathrm{~mL}$ beakers \\
Sediment Volume: $\quad 100 \mathrm{~mL}$ \\
Sediment Depth $4 \mathrm{~cm}$ \\
$\begin{array}{l}\text { Overlying Water Volume: } \quad 175 \mathrm{~mL} \\
\text { Overlying Water Depth: } \quad 5 \mathrm{~cm} \\
\text { Aeration: Not needed }\end{array}$ \\
\hline
\end{tabular}




\section{DAY AMPHIPOD SEDIMENT TOXICITY TEST}

\begin{tabular}{|l|l|l|l|}
\hline Lab ID\# & Client: $\quad$ WSRC & Start Date: & 1/15/99 \\
\cline { 2 - 5 } T11114 & Sample Identification: $\quad$ CBS-47-01-R & End Date: & $1 / 25 / 99$ \\
\hline
\end{tabular}

\section{WATER CHEMISTRY TEST METHODS}

Temperature: SM 18th Ed. 2550

Dissolved Oxygen: SM 18th Ed. 4500-O

pH: SM 18th Ed. 4500-H+
Alkalinity: SM 18th Ed. 2320
Hardness: SM 18 th Ed. 2340
Conductivity: SM 18 th Ed. 2510

\section{WATER CHEMISTRY TEST DATA - OVERLYING WATER}

CONTROL TREATMENT

\begin{tabular}{|c|c|c|c|c|c|c|}
\hline & Temp. & $\mathrm{pH}$ & D.O. & D.O. & Alkalinity & Ammonia \\
\hline Test Day & & & & $\%$ sat. & Initial & \multirow[t]{2}{*}{ Initial } \\
\hline Start & & & & & 6.2 & \\
\hline 1 & 24.0 & 6.83 & 8.5 & $99 \%$ & Final & Final \\
\hline 2 & 24.0 & 7.26 & 8.4 & $98 \%$ & 12.5 & 0.70 \\
\hline 3 & 23.7 & 7.63 & 8.4 & $98 \%$ & $\mathrm{mgh}$ & $\mathrm{mgh}$ \\
\hline 4 & 23.5 & 6.79 & 7.8 & $91 \%$ & Cond. & Hardness \\
\hline 5 & 23.9 & 7.70 & 8.3 & $97 \%$ & tritial & Initial \\
\hline 6 & 23.6 & 7.20 & 8.5 & $99 \%$ & 41 & 8.2 \\
\hline 7 & 23.2 & 7.95 & 7.4 & $86 \%$ & Final & Final \\
\hline 8 & 23.2 & 6.64 & 8.1 & $94 \%$ & & 14.3 \\
\hline 9 & 23.6 & 7.58 & 7.9 & $92 \%$ & umtros/cm & $\mathrm{mgh}$ \\
\hline 10 & & & & & \multicolumn{2}{|c|}{ Aeration: none } \\
\hline
\end{tabular}

\section{SURVIVAL AND GROWTH RESULTS}

CONTROL TREATMENT

\begin{tabular}{|c|c|c|c|c|c|c|}
\hline & \multicolumn{3}{|c|}{ \# Organisms } & \multirow[b]{2}{*}{$\begin{array}{c}\% \\
\text { Survival } \\
\end{array}$} & \multirow{2}{*}{$\begin{array}{l}\text { Mean } \\
\text { Length } \\
(\mathrm{mm})\end{array}$} & \multirow{2}{*}{$\begin{array}{l}\text { Standard } \\
\text { Deviation }\end{array}$} \\
\hline & Initial & $\begin{array}{c}\text { Live at } \\
\text { End }\end{array}$ & $\begin{array}{l}\text { Dead } \\
\text { at End }\end{array}$ & & & \\
\hline $\mathrm{A}$ & 10 & 10 & 0 & $100 \%$ & & \\
\hline B & 10 & 9 & 1 & $90 \%$ & & \\
\hline C & 10 & 8 & 2 & $80 \%$ & & \\
\hline D & 10 & 8 & 2 & $80 \%$ & & \\
\hline$E$ & 10 & 9 & 1 & $90 \%$ & & \\
\hline $\mathrm{F}$ & 10 & 8 & 2 & $80 \%$ & & \\
\hline $\bar{G}$ & 10 & 10 & 0 & $100 \%$ & & \\
\hline $\mathrm{H}$ & 10 & 9 & 1 & $90 \%$ & & \\
\hline Mean & 10.0 & & & $89 \%$ & 0.00 & \\
\hline
\end{tabular}

SAMPLE TREATMENT

\begin{tabular}{|c|c|c|c|c|c|c|}
\hline & Temp. & $\mathrm{pH}$ & D.O. & D.O. & Alkalinity & Ammonia \\
\hline Test Day & & units & $\mathrm{mg} / \mathrm{L}$ & & Initid & Initial \\
\hline \multicolumn{7}{|l|}{ Start } \\
\hline 1 & 24.0 & 7.67 & 8.4 & $98 \%$ & Final & Final \\
\hline 2 & 24.0 & 6.93 & 8.8 & $102 \%$ & 8.3 & 0.11 \\
\hline 3 & 23.7 & 7.27 & 8.6 & $100 \%$ & $m g h$ & $\mathrm{mgr}$ \\
\hline 4 & 23.5 & 7.08 & 8.0 & $93 \%$ & Cond. & Hardness \\
\hline 5 & 23.9 & 7.50 & 8.1 & $94 \%$ & Initial & Initial \\
\hline 6 & 23.6 & 7.58 & 8.7 & $101 \%$ & 41 & 8.2 \\
\hline 7 & 23.2 & 7.01 & 8.1 & $94 \%$ & Final & Final \\
\hline 8 & 23.2 & 7.48 & 8.5 & $99 \%$ & & 8.2 \\
\hline 9 & 23.6 & 7.10 & 8.5 & $99 \%$ & urmhos/cm & $\mathrm{mgh}$ \\
\hline 10 & & & & & Aeration: $\mathrm{n}$ & \\
\hline
\end{tabular}

SAMPLE TREATMENT

\begin{tabular}{|l|r|r|r|r|l|l|}
\hline & \multicolumn{3}{|c|}{ \# Organisms } & & Mean & Standard \\
& Initial & $\begin{array}{c}\text { Live at } \\
\text { End }\end{array}$ & $\begin{array}{c}\text { Dead } \\
\text { at End }\end{array}$ & $\begin{array}{c}\% \\
\text { Survival }\end{array}$ & $\begin{array}{l}\text { Length } \\
\text { (mm) }\end{array}$ & Deviation \\
\hline A & 10 & 8 & 2 & $80 \%$ & & \\
\hline B & 10 & 10 & 0 & $100 \%$ & & \\
\hline D & 10 & 7 & 3 & $70 \%$ & & \\
\hline E & 10 & 7 & 3 & $70 \%$ & & \\
\hline F & 10 & 9 & 1 & $90 \%$ & & \\
\hline G & 10 & 7 & 3 & $70 \%$ & & \\
\hline H & 10 & 6 & 4 & $60 \%$ & & \\
\hline Mean & 10 & 7 & 3 & $70 \%$ & & \\
\hline
\end{tabular}




\section{DAY AMPHIPOD SEDIMENT TOXICITY TEST}

\begin{tabular}{|c|c|c|c|}
\hline \multirow{2}{*}{$\begin{array}{l}\text { Lab ID\# } \\
\text { T11114 }\end{array}$} & Client: & Start Date: & $1 / 15 / 99$ \\
\hline & Sample Identification: $\quad$ CBS-47-01-R & End Date: & $1 / 25 / 99$ \\
\hline
\end{tabular}

\section{RESULTS}

\begin{tabular}{|l|c|}
\hline \multicolumn{2}{|c|}{$\begin{array}{c}\text { SURVIVAL DATA } \\
\text { Mean of Eight Replicates }\end{array}$} \\
\cline { 2 - 2 } & Mean \% \\
\hline Control & $88.8 \%$ \\
\hline Sample & $76.3 \%$ \\
\hline
\end{tabular}

\begin{tabular}{|l|l|}
\hline \multicolumn{2}{|c|}{ GROWTH DATA } \\
Mean Length (mm) \\
& \multicolumn{1}{|c|}{ Mean } \\
\hline Control & NA \\
\hline Sample & NA \\
\hline
\end{tabular}

\section{STATISTICAL ANALYSES}

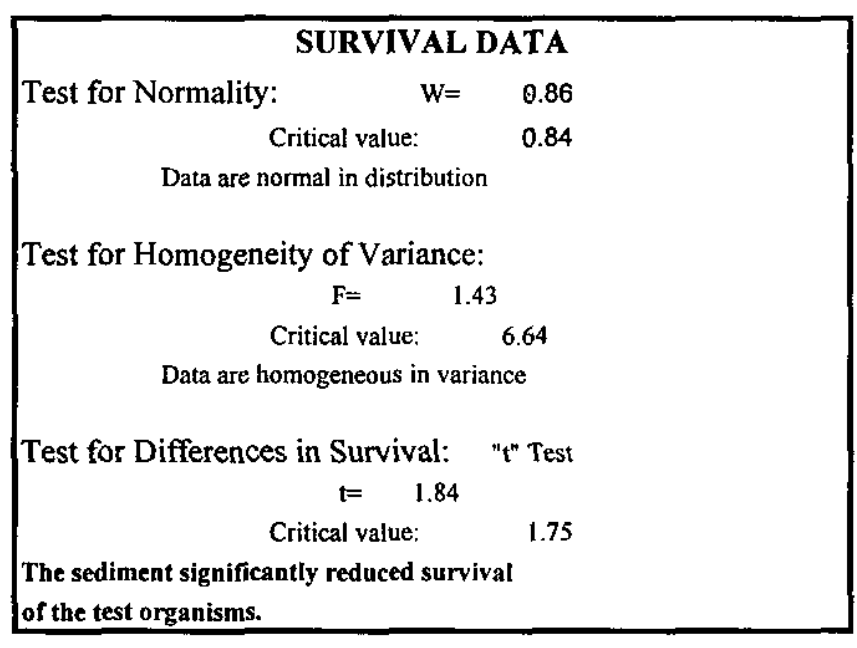

\begin{tabular}{|l}
\hline \multicolumn{3}{c|}{ GROWTH DATA } \\
Test for Normality: $\quad$ W= NA \\
Critical value: $\quad 0.84$ \\
Test for Homogeneity of Variance: \\
F= $\quad$ NA \\
Critical value: $\quad 6.635$ \\
Test for Differences in Survival: " $t$ " Test \\
$t=$ NA \\
Critical value:
\end{tabular}

\section{COMMENTS}

None

Principal Analyst:

Report Reviewed By: Robert W. Kelley, Ph.D.

Signature:

Date:

\section{CONCLUSIONS}

The sediment does adversely affect the survival of freshwater amphipods. 


\title{
10 DAY AMPHIPOD SEDIMENT TOXICITY TEST
}

\author{
EPA/600/R-94/024 Method 100.1
}

Test Organism: Hyallela azteca

\author{
Client: WSRC \\ Sample Identification: $\quad$ CBS-48-01-R
}

Test Start Date: $\quad 1 / 15 / 99$ 


\section{DAY AMPHIPOD SEDIMENT TOXICITY TEST}

\begin{tabular}{|l|l|l|l|}
\hline Lab ID\# & Client: $\quad$ WSRC & Start Date: & $1 / 15 / 99$ \\
\cline { 2 - 4 } T11 115 & Sample Identification: $\quad$ CBS-48-01-R & End Date: & $1 / 25 / 99$ \\
\hline
\end{tabular}

Test System

EPA/600/R-94/024 Method 100.1

The test was set as a Pass/Fail test with a control treatment and one sample treatment. Each treatment replicate consisted of $100 \mathrm{~g}$ of sediment and $175 \mathrm{~mL}$ of dilution water. There were eight replicates for each treatment. Ten test organisms were placed in each replicate. Sediment from a local stream was used in the control treatment. Test organisms were fed with YCT food. The test was conducted at a temperature of $23^{\circ} \mathrm{C}$ and a light cycle of $16 \mathrm{hr}$ light $/ 8 \mathrm{hr}$ dark. Test vessels were $500 \mathrm{~mL}$ plastic beakers placed in a constant temperature incubator room.

Order: Amphipoda

Species: Hyallela azteca

Source: ETT Environmental cultures

Life Stage: $\quad 7$ to 14 days old

\% Mortality During $48 \mathrm{Hr}$ Prior to Test::

Taxonomic Verification: RWK 1/15/99

Culturing: mass cultures

Observations: Cultures healthy

Acclimation: None

\begin{tabular}{|lr|}
\hline \multicolumn{2}{|c|}{ Dilution Water } \\
Type: Resurrection Creek & Initial \\
Collection Date 1/15/99 & $6.2 \mathrm{mg} / \mathrm{L}$ \\
Alkalinity & $8.2 \mathrm{mg} / \mathrm{L}$ \\
Hardness & 41 umbos/cm \\
Conductivity & 6.16 units \\
$p H:$ & \\
Preparation Method: & \\
Grab sample & \\
& \\
\hline
\end{tabular}

\section{Test Sediment}

Source: CBS-46-01-R

Collection Date 1/11/99 Homogenized?:

Preservation: kept at $0-4^{\circ} \mathrm{C}$ in plastic

Date/Time Added to Test Chambers: 1/15/99 (1PM

Observations: sandy

Collection Method: grab

Shipment: overnight
Disposal:

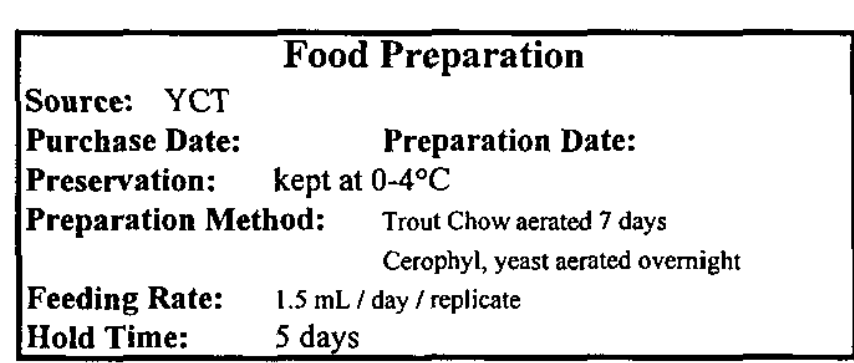

\section{Test Chambers}

Type: Plastic $500 \mathrm{~mL}$ beakers

Sediment Volume: $\quad 100 \mathrm{~mL}$

Sediment Depth $4 \mathrm{~cm}$

Overlying Water Volume: $175 \mathrm{~mL}$

Overlying Water Depth: $5 \mathrm{~cm}$

Aeration: Not needed 


\section{DAY AMPHIPOD SEDIMENT TOXICITY TEST}

\begin{tabular}{|c|c|c|c|}
\hline \multirow{2}{*}{\begin{tabular}{|l} 
Lab ID\# \\
T11115
\end{tabular}} & Client: $\quad$ WSRC & Start Date: & $1 / 15 / 99$ \\
\hline & Sample Identification: $\quad$ CBS-48-0I-R & End Date: & $1 / 25 / 99$ \\
\hline
\end{tabular}

\section{WATER CHEMISTRY TEST METHODS}

\begin{tabular}{|l|l|}
\hline Temperature: SM 18th Ed. 2550 & Alkalinity: SM 18th Ed. 2320 \\
Dissolved Oxygen: SM 18th Ed. 4500-O & Hardness: SM 18th Ed. 2340 \\
pH: SM 18th Ed. 4500-H+ & Conductivity: SM 18th Ed. 2510 \\
\hline
\end{tabular}

\section{WATER CHEMISTRY TEST DATA - OVERLYING WATER}

CONTROL TREATMENT

\begin{tabular}{|c|c|c|c|c|c|c|}
\hline & Temp. & $\mathrm{pH}$ & D.O. & D.O. & Alkalinity & Ammonia \\
\hline Test Day & C & units & $\mathrm{mg} / \mathrm{L}$ & $\%$ sat. & Initial & Initial \\
\hline Start & & & & & 6.2 & \\
\hline 1 & 24.0 & 6.83 & 8.5 & $99 \%$ & Final & Final \\
\hline 2 & 24.0 & 7.26 & 8.4 & $98 \%$ & 12.5 & 0.70 \\
\hline 3 & 23.7 & 7.63 & 8.4 & $98 \%$ & mgl & $\mathrm{mgh}$ \\
\hline 4 & 23.5 & 6.79 & 7.8 & $91 \%$ & Cond. & Hardness \\
\hline 5 & 23.9 & 7.70 & 8.3 & $97 \%$ & Initial & Initial \\
\hline 6 & 23.6 & 7.20 & 8.5 & $99 \%$ & $4 I$ & 8.2 \\
\hline 7 & 23.2 & 7.95 & 7.4 & $86 \%$ & Final & Final \\
\hline 8 & 23.2 & 6.64 & 8.1 & $94 \%$ & & 14.3 \\
\hline 9 & 23.6 & 7.58 & 7.9 & $92 \%$ & umthos/cm & $m g h$ \\
\hline 10 & & & & & \multicolumn{2}{|c|}{ Aeration: none } \\
\hline
\end{tabular}

SAMPLE TREATMENT

\begin{tabular}{|c|c|c|c|c|c|c|}
\hline \multirow{3}{*}{$\frac{\text { est Day }}{\text { Start }}$} & Temp. & $\mathrm{pH}$ & D.o. & D.O. & Alkalinity & Ammonia \\
\hline & $\mathrm{C}$ & units & $\mathrm{mg} / \mathrm{L}$ & $\%$ sat. & \multirow{2}{*}{$\begin{array}{c}\text { Initial } \\
6.2\end{array}$} & \multirow[t]{2}{*}{ Initial } \\
\hline & & & & & & \\
\hline 1 & 24.0 & 6.64 & 8.3 & $97 \%$ & Final & \multirow{3}{*}{$\begin{array}{c}\text { Final } \\
0.65\end{array}$} \\
\hline 2 & 24.0 & 6.54 & 8.7 & $101 \%$ & 10.4 & \\
\hline 3 & 23.7 & 7.00 & 8.7 & $101 \%$ & $m g h$ & \\
\hline 4 & 23.5 & 6.93 & 8.1 & $94 \%$ & Cond. & Hardness \\
\hline 5 & 23.9 & 6.95 & 8.2 & $95 \%$ & Initial & Initial \\
\hline 6 & 23.6 & 7.24 & 8.6 & $100 \%$ & 41 & 8.2 \\
\hline 7 & 23.2 & 7.67 & 8.1 & $94 \%$ & Finat & Final \\
\hline 8 & 23.2 & 6.58 & 8.5 & $99 \%$ & & 10.2 \\
\hline 9 & 23.6 & 7.08 & $\overrightarrow{7.6}$ & $88 \%$ & umhos/cm & $\mathrm{mgh}$ \\
\hline 10 & & & & & Aeration: $n$ & \\
\hline
\end{tabular}

\section{SURVIVAL AND GROWTH RESULTS}

CONTROL TREATMENT

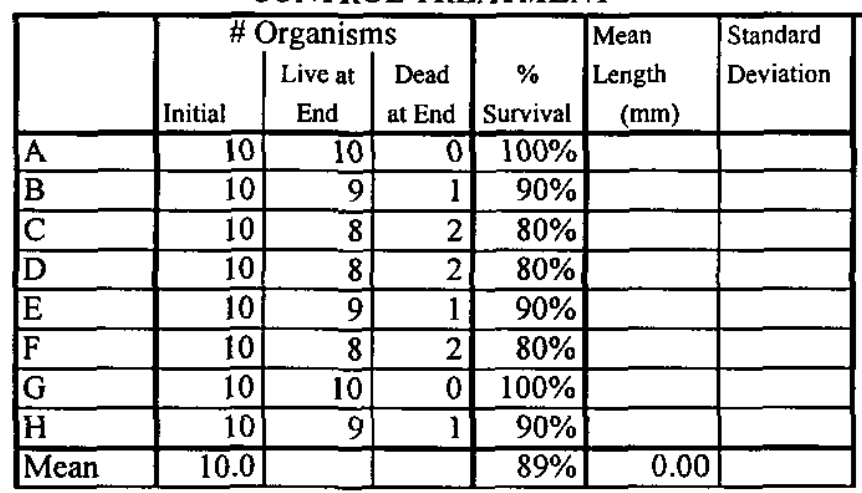

SAMPLE TREATMENT

\begin{tabular}{|c|c|c|c|c|c|c|}
\hline & \multicolumn{3}{|c|}{ \# Organisms } & \multirow[b]{2}{*}{$\begin{array}{c}\% \\
\text { Survival }\end{array}$} & \multirow{2}{*}{\begin{tabular}{|l} 
Mean \\
Length \\
$(\mathrm{mm})$
\end{tabular}} & \multirow{2}{*}{$\begin{array}{l}\text { Standard } \\
\text { Deviation }\end{array}$} \\
\hline & Initial & $\begin{array}{l}\text { Live at } \\
\text { End }\end{array}$ & $\begin{array}{l}\text { Dead } \\
\text { at End }\end{array}$ & & & \\
\hline A & 10 & 9 & 1 & $90 \%$ & & \\
\hline$\overline{\mathrm{B}}$ & 10 & $\overline{7}$ & $\overline{3}$ & $70 \%$ & & \\
\hline$\widehat{\mathrm{C}}$ & 10 & 7 & 3 & $70 \%$ & & \\
\hline D & 10 & 3 & 7 & $30 \%$ & & \\
\hline $\bar{E}$ & 10 & 5 & 5 & $50 \%$ & & \\
\hline $\mathrm{F}$ & 10 & 10 & 0 & $100 \%$ & & \\
\hline $\mathrm{G}$ & 10 & 5 & 5 & $50 \%$ & & \\
\hline $\mathrm{H}$ & 10 & 8 & 2 & $80 \%$ & & \\
\hline Mean & 10.0 & & & $68 \%$ & 0.00 & \\
\hline
\end{tabular}




\section{DAY AMPHIPOD SEDIMENT TOXICITY TEST}

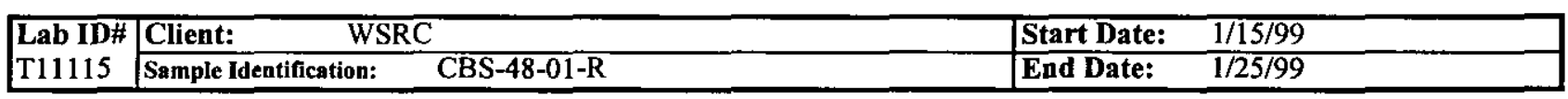

\section{RESULTS}

\begin{tabular}{|l|c|}
\hline \multicolumn{2}{|c|}{$\begin{array}{c}\text { SURVIVAL DATA } \\
\text { Mean of Eight Replicates }\end{array}$} \\
\cline { 2 - 2 } & Mean \% \\
\hline Control & $88.8 \%$ \\
\hline Sample & $67.5 \%$ \\
\hline
\end{tabular}

\begin{tabular}{|c|c|c|}
\hline \multicolumn{3}{|c|}{ GROWTH DATA } \\
\hline & & Mean \\
\hline Control & & 0.00 \\
\hline Sample & & 0.00 \\
\hline
\end{tabular}

\section{STATISTICAL ANALYSES}

SURVIVAL DATA
Test for Normality: $\quad \mathrm{W}=\quad 0.95$
Critical value: $\quad 0.84$
Data are normal in distribution
Test for Homogeneity of Variance:
$\quad \mathrm{F}=\quad 3.03$
Critical value: 6.64
Data are homogeneous in variance
Test for Differences in Survival: $\quad \mathrm{t}$ " Test
$\mathrm{t}=\quad 2.18$
Critical value:
The sediment significantly reduced survival
of the test organisms.

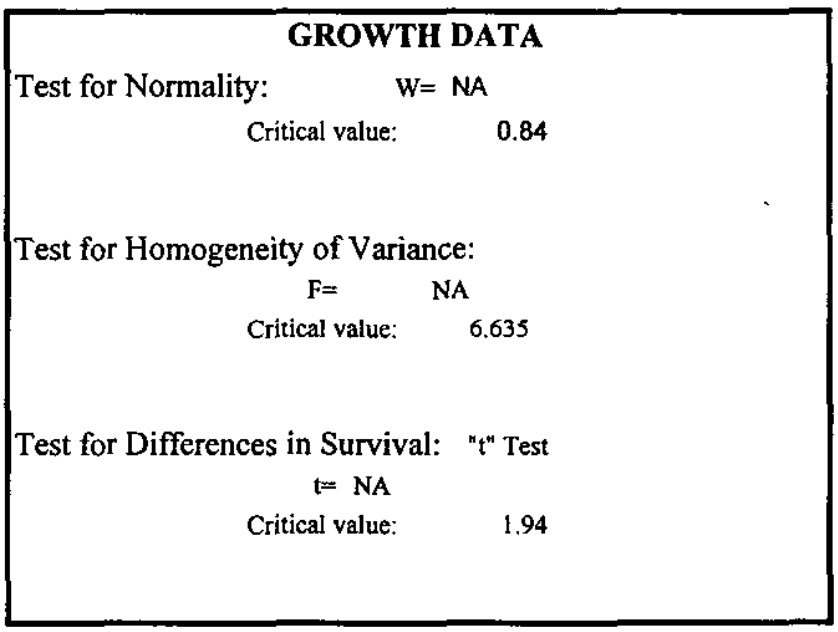

\section{COMMENTS}

\section{None}

Principal Analyst:
Report Reviewed By: Robert W. Kelley, Ph.D

\section{CONCLUSIONS}

The sediment does adversely affect the survival of freshwater amphipods. 


\section{APPENDIX 3}

Results of Statistical Analyses for Sediment Toxicity Tests, Using SRS Background Sediment as the Control 
Mortality (\# dead out of 10 organisms)

$\begin{array}{lrcccccc}\text { Replicate } & \text { ETT Control } & \text { SRS Control } & \text { CSBRP-45 } & \text { CSBRP-46 } & \text { CSBRP-47 } & \text { CSBRP-48 } \\ \text { A } & 100 & 70 & 70 & \text { NA } & 80 & 90 \\ \text { B } & 90 & 80 & 60 & 80 & 100 & 70 \\ \text { C } & 80 & 80 & 80 & 70 & 70 & 70 \\ \text { D } & 80 & 70 & 50 & 90 & 70 & 30 \\ \text { E } & 90 & 80 & 70 & 70 & 90 & 50 \\ \text { F } & 80 & 60 & 70 & 60 & 70 & 100 \\ \text { G } & 100 & 80 & 80 & 100 & 60 & 50 \\ \text { H } & 90 & 80 & 70 & 100 & 70 & 80 \\ \text { Mean Mortality } & 88.75 & 75.00 & 68.75 & 81.43 & 76.25 & 67.50\end{array}$

t-Test: Two-Sample Assuming Equal Variances

\begin{tabular}{lrr}
\hline & SRS Control & CSBRP-45 \\
\hline Mean & 75 & 68.75 \\
Variance & 57.14285714 & 98.2142857 \\
Observations & 8 & 8 \\
Pooled Variance & 77.67857143 & \\
Hypothesized Mean Diffe & 0 & \\
df & 14 & \\
t Stat & 1.418271572 & \\
P(T<=t) one-tail & 0.088993255 & \\
t Critical one-tail & 1.76130925 & \\
P(T<=t) two-tail & 0.177986511 & \\
t Critical two-tail & 2.144788596 & \\
\hline
\end{tabular}

t Statististic is less than Critical T, cannot reject Ho: groups equal (i.e., no significant difference in \% survival)

t-Test: Two-Sample Assuming Equal Variances

\begin{tabular}{lrr}
\hline & SRS Control & CSBRP-46 \\
\hline Mean & 75 & $\mathbf{8 1 . 4 2 8 5 7 1 4}$ \\
Variance & 57.14285714 & 247.619048 \\
Observations & 8 & 7 \\
Pooled Variance & 145.0549451 & \\
Hypothesized Mean Diffe & 0 & \\
df & 13 & \\
t Stat & -1.03132748 & \\
P(T<=t) one-tail & 0.160596844 & \\
t Critical one-tail & 1.770931704 & \\
P(T<=t) two-tail & 0.321193687 & \\
t Critical two-tail & 2.16036824 & \\
\hline
\end{tabular}

t Statististic is less than Critical T, cannot reject Ho: groups equal (i.e., no significant difference in \% survival) 
t-Test: Two-Sample Assuming Equal Variances

\begin{tabular}{lrr}
\hline & SRS Control & CSBRP-47 \\
\hline Mean & 75 & 76.25 \\
Variance & 57.14285714 & 169.642857 \\
Observations & 8 & 8 \\
Pooled Variance & 113.3928571 & \\
Hypothesized Mean Diffe & 0 & \\
df & 14 & \\
t Stat & -0.23477246 & \\
P(T<=t) one-tail & 0.40889216 & \\
t Critical one-tail & 1.76130925 & \\
P(T<=t) two-tail & 0.81778432 & \\
$t$ Critical two-tail & 2.144788596 & \\
\hline
\end{tabular}

t Statististic is less than Critical $T$, cannot reject Ho: groups equal (i.e., no significant difference in \% survival)

t-Test: Two-Sample Assuming Equal Variances

\begin{tabular}{lrr}
\hline & SRS Control & CSBRP-48 \\
\hline Mean & 75 & 67.5 \\
Variance & 57.14285714 & 535.714286 \\
Observations & 8 & 8 \\
Pooled Variance & 296.4285714 & \\
Hypothesized Mean Diffe & 0 & \\
df & 14 & \\
t Stat & 0.871226804 & \\
P(T<=t) one-tail & 0.199162216 & \\
t Critical one-tail & 1.76130925 & \\
P(T<=t) two-tail & 0.398324431 & \\
t Critical two-tail & 2.144788596 & \\
\hline
\end{tabular}

t Statististic is less than Critical T, cannot reject Ho: groups equal (i.e., no significant difference in \% survival) 